\title{
RESPOSTAS DO CAPIM-MARANDU A COMBINAÇÕES DE DOSES DE NITROGÊNIO E ENXOFRE
}

\author{
KARINA BATISTA
}

Dissertação apresentada à Escola Superior de Agricultura “ Luiz de Queiroz", Universidade de São Paulo, para obtenção do título de Mestre em Agronomia, Área de Concentração: Solos e Nutrição de Plantas.

PIRACICABA

Estado de São Paulo - Brasil

Dezembro - 2002 


\title{
RESPOSTAS DO CAPIM-MARANDU A COMBINAÇÕES DE DOSES DE NITROGÊNIO E ENXOFRE
}

\author{
KARINA BATISTA
}

Engenheiro Agrônomo

Orientador : Prof.Dr. FRANCISCO ANTONIO MONTEIRO

Dissertação apresentada à Escola Superior de Agricultura 'Luiz de Queiroz", Universidade de São Paulo, para obtenção do título de Mestre em Agronomia, Área de Concentração: Solos e Nutrição de Plantas.

PIRACICABA

Estado de São Paulo - Brasil

Dezembro - 2002 


\section{Dados Internacionais de Catalogação na Publicação (CIP)}

DIVISÃO DE BIBLIOTECA E DOCUMENTAÇÃO - ESALQ/USP

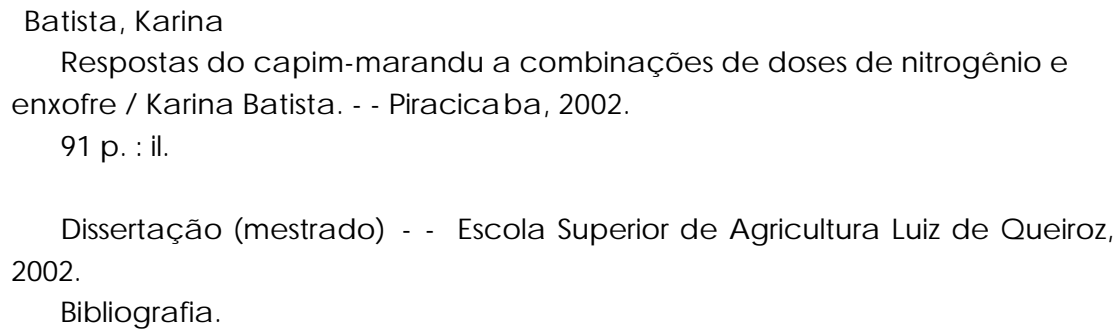

1. Capim marandu 2. Clorofila 3. Dosagem 4. Perfilhamento 5. Relação nitrogênio-en-xofre 6. Solução nutritiva I. Título

CDD 633.2

"Permitida a cópia total ou parcial deste documento, desde que citada a fonte - $\mathrm{O}$ autor" 
Aos meus queridos irmãos

James e Tiago

pelo amor, amizade e força

OFEREÇO

\author{
Aos meus queridos pais \\ Emerildo e Aparecida Elisa \\ pelo amor, apoio e incentivo \\ DEDICO
}




\section{Agradecimentos}

A Deus e a Nossa Senhora por terem me iluminado e me acompanhado até agora em todas as etapas de minha vida.

Ao Prof. Dr. Francisco Antonio Monteiro, pela convivência, orientação, confiança e amizade.

Aos Professores Antonio Roque Dechen e Quirino Augusto de Camargo Carmello pela convivência, aprendizagem e amizade.

Ao Prof. Dr. Silvio José Bicudo pela amizade e orientação em minha graduação.

A todos os professores do Programa de Pós Graduação em Solos e Nutrição de Plantas pelos conhecimentos transmitidos.

Às funcionárias do setor de Nutrição Mineral de Plantas Ednéia C. S. Mondoni, Lúcia H. S. P. Forti, Lurdes A. D. de González, Nivanda M. de Moura, e Sueli M. A. C. Bovi pelo apoio, convívio e amizade.

Aos estagiários da Nutrição Mineral de Plantas pela ajuda na condução deste trabalho.

Aos companheiros de curso João de Deus Gomes dos Santos Junior, José Lavres Junior e Jorge Henrique dos Santos pela ajuda concedida.

A todos os amigos que me ajudaram de alguma forma na elaboração deste trabalho e em especial às amigas de todas as horas Aline Marques Genú e Glaucia Tiemi Yorinori.

Ás amigas Adriana Teramoto, Cristiaine Kano, Geni da Silva Sodré e Marisa Azolline pelo convívio e amizade desenvolvida.

Aos meus avós Angelina e Antonio, às minhas tias Amarilda e Rita e aos meus primos Roninho, Cassiane e Flavinha meu muito obrigado por estarem sempre presentes em cada etapa de nossas vidas. 
À Faculdade de Ciências Agronômicas - UNESP pela minha formação na graduação.

À FAPESP pela concessão da bolsa de mestrado e pelo apoio institucional prestado para a realização deste trabalho.

À Escola Superior de Agricultura "Luiz de Queiroz" - USP e à Coordenação do Programa de Pós-Graduação em Solos e Nutrição de Plantas pela realização do curso. 


\section{SUMÁRIO}

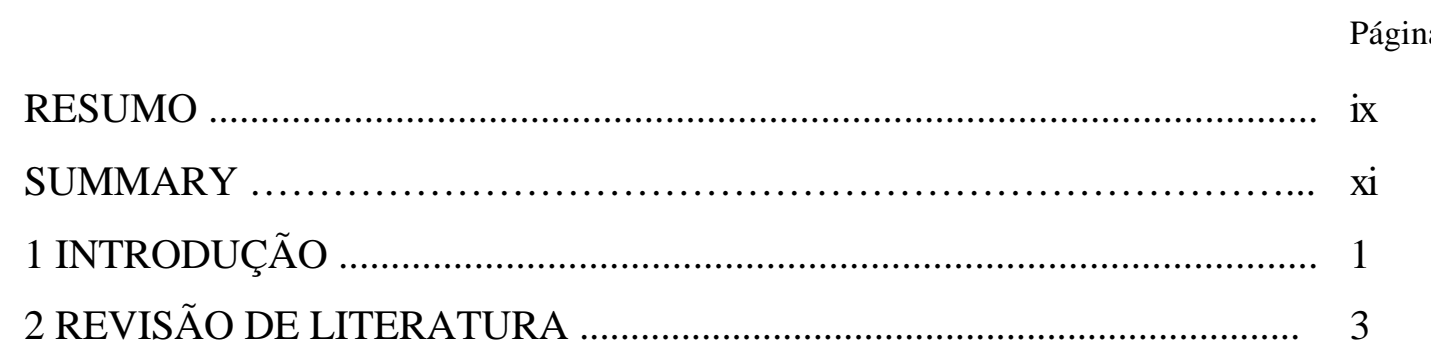

2.1 Brachiaria brizantha Stapf cv. Marandu....................................................... 3

2.2 Nitrogênio ........................................................................................ 4

2.2.1 Fornecimento de nitrogênio e produção de gramíneas forrageiras........... 4

2.2.2 Fornecimento de nitrogênio e concentração de nitrogênio em capins....... 7

2.3 Enxofre........................................................................................

2.3.1 Fornecimento de enxofre e produção de gramíneas forrageiras................. 8

2.3.2 Fornecimento de enxofre e concentração de enxofre em capins............... 10

2.4 Relação nitrogênio:enxofre ....................................................................... 11

2.5 Nitrogênio e enxofre no perfilhamento e taxa de aparecimento de folhas... 15

2.7 Área foliar ...................................................................................... 18

2.8 Redutase do nitrato ........................................................................... 18

2.9 Estimativa do teor de clorofila através do valor SPAD................................. 19

2.10 Sistema radicular ................................................................................... 21

3 MATERIAL E MÉTODOS ………………………………………..... 24

3.1 Local, espécie forrageira e período do experimento .................................... 24

3.2 Doses de nitrogênio e de enxofre, soluções nutritivas e delineamento

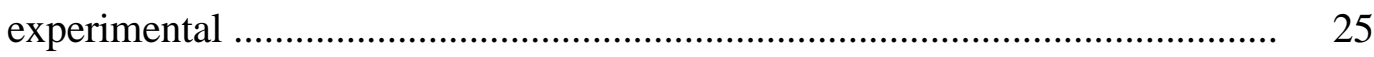

3.3 Instalação e condução do experimento ....................................................... 26

3.4 Estimativa do teor de clorofila através do valor SPAD ................................ 27 


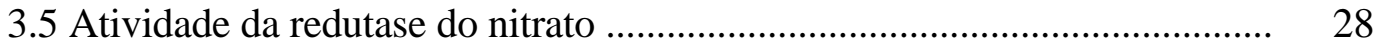

3.6 Avaliação da área foliar .................................................................... 28

3.7 Avaliação da superfície total e comprimento total do sistema radicular ..... 29

3.8 Produção de massa seca ……………………………………………….... 29

3.9 Composição mineral .............................................................................. 29

3.10 Análises estatísticas ............................................................................... 30

4 RESULTADOS E DISCUSSÃO ........................................................... 31

4.1 Número de perfilhos e de folhas ........................................................... 31

4.1.1 Número total de perfilhos por vaso ........................................................ 31

4.1.2 Número total de folhas verdes expandidas por vaso ................................ 34

4.2 Estimativa do teor de clorofila em unidades de SPAD ................................ $\quad 37$

4.3 Atividade da redutase do nitrato ………………………………………... $\quad 39$

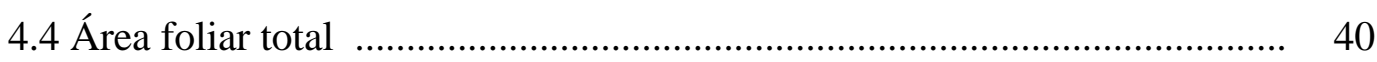

4.5 Comprimento total e superfície total do sistema radicular ........................ 42

4.6 Produção de massa seca da planta ................................................................. 44

4.6.1 Produção de massa seca da parte aérea ....................................................... 44

4.6.2 Produção de massa seca das raízes ............................................................. 47

4.7 Concentração de nutrientes na planta ....................................................... 48

4.7.1 Concentração de nitrogênio nas folhas emergentes ...................................... 48

4.7.2 Concentração de nitrogênio nas lâminas de folhas recém-expandidas ..... $\quad 50$

4.7.3 Concentração de nitrogênio nas lâminas de folhas maduras ..................... 54

4.7.4 Concentração de nitrogênio nos colmos + bainhas ................................... $\quad 55$

4.7.5 Concentração de nitrogênio nas raízes ....................................................... 56

4.7.6 Concentração de enxofre nas folhas emergentes ..................................... 58

4.7.7 Concentração de enxofre nas lâminas de folhas recém-expandidas ........ $\quad 59$

4.7.8 Concentração de enxofre nas lâminas de folhas maduras .......................... 63

4.7.9 Concentração de enxofre nos colmos + bainhas ........................................ 65

4.7.10 Concentração de enxofre nas raízes ....................................................... 66

4.7.11 Concentração de fósforo nas lâminas de folhas recém-expandidas ......... 67

4.7.12 Concentração de potássio nas lâminas de folhas recém-expandidas ..... $\quad 69$ 
4.7.13 Concentração de cálcio nas lâminas de folhas recém-expandidas .......... 70

4.7.14 Concentração de magnésio lâminas de folhas recém-expandidas .......... 72

4.8 Relação N:S na planta ........................................................................... 74

4.8.1 Relação N:S folhas emergentes ............................................................ 74

4.8.2 Relação N:S nas lâminas de folhas recém-expandidas ......................... 76

4.8.3 Relação N:S nas lâminas de folhas maduras ......................................... 78

4.8.4 Relação N:S nos colmos mais bainhas e nas raízes ................................ $\quad 80$

4.9 Sintomatologia de carência de nitrogênio e enxofre 81

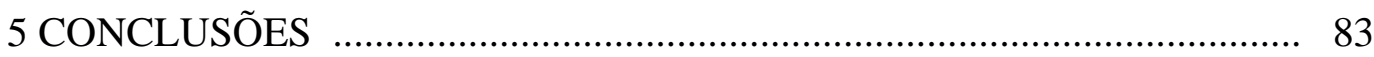

REFERÊNCIAS BIBLIOGRÁFICAS …............................................ 84 


\title{
RESPOSTAS DO CAPIM-MARANDU A COMBINAÇÕES DE DOSES DE NITROGÊNIO E ENXOFRE
}

\author{
Autor: KARINA BATISTA \\ Orientador: Prof. Dr. FRANCISCO ANTONIO MONTEIRO
}

\section{RESUMO}

A baixa disponibilidade de nutrientes na exploração da pastagem é um dos principais fatores que interfere tanto na produtividade como na qualidade da forrageira. O presente trabalho objetivou avaliar os efeitos de combinações de doses de nitrogênio com doses de enxofre para a Brachiaria brizantha cv. Marandu, cultivada em solução nutritiva, utilizando sílica como substrato, em um experimento conduzido em casa-devegetação, em Piracicaba-SP, no período de setembro a dezembro de 2001. Utilizou-se um esquema fatorial $5^{2}$ fracionado, com 13 combinações assim definidas, para nitrogênio e enxofre na solução nutritiva: 14 e 3,2; 14 e 32; 14 e 80; 126 e 12,8; 126 e 64; 210 e 3,2; 210 e 32; 210 e 80; 336 e 12,8; 336 e 64; 462 e 3,2; 462 e 32 e 462 e

$80 \mathrm{mg} \mathrm{L} \mathrm{L}^{-1}$, as quais foram distribuídas segundo delineamento estatístico de blocos ao acaso, com quatro repetições. Foram realizados dois cortes nas plantas, ocasiões em que se separou a parte aérea em folhas emergentes, lâminas de folhas recém-expandidas, lâminas de folhas maduras e colmos mais bainhas. Após o segundo corte as raízes foram separadas do substrato e tiveram o comprimento e a superfície avaliados. Os resultados 
demonstraram que a interação entre as doses de nitrogênio e enxofre foi significativa para o número total de perfilhos, o número total de folhas expandidas, o teor de clorofila, a área foliar, a produção de massa seca da parte aérea, a concentração de nitrogênio em folhas emergentes e nas raízes, a concentração de enxofre e a relação N:S em folhas emergentes, lâminas de folhas recém-expandidas e lâminas de folhas maduras em um ou ambos os cortes. Para a atividade da redutase do nitrato não foi observada significância quer para a interação entre as doses de nitrogênio e enxofre, quer para as doses individuais de nitrogênio e enxofre. A máxima concentração de nitrogênio (31,6 g $\mathrm{kg}^{-1}$ ) nos componentes do capim foi observada nas folhas emergentes na dose de nitrogênio de $462 \mathrm{mg} \mathrm{L}^{-1}$ por ocasião do primeiro corte. Para o enxofre a máxima concentração $\left(2,8 \mathrm{~g} \mathrm{~kg}^{-1}\right)$ foi observada nos colmos+bainhas na dose de nitrogênio de 14 $\mathrm{mg} \mathrm{L}^{-1}$, à época do segundo corte. A relação $\mathrm{N}: \mathrm{S}$ nas lâminas de folhas recémexpandidas variou de 2,8:1 a 37,2:1 sendo o mínimo observado com muito baixo suprimento de nitrogênio e o máximo dessa relação ocorrendo com fornecimento de alta dose de nitrogênio combinada com baixa disponibilidade de enxofre. É necessário suprir enxofre quando se incrementa a disponibilidade de nitrogênio para o capim-Marandu. 


\section{RESPONSE OF THE MARANDU GRASS TO COMBINATIONS OF NITROGEN AND SULPHUR RATES}

Author: KARINA BATISTA

Adviser: Prof. Dr. FRANCISCO ANTONIO MONTEIRO

\section{SUMMARY}

The low availability of nutrients in the exploration of the grassland is one of the main factors to interfere in grass productivity and quality. This experiment had the objectives of evaluating the effects of combinations of nitrogen and sulphur rates to Brachiaria brizantha cv. Marandu, grown in nutrient solution, using ground quartz as substrate. The experiment was carried out in a greenhouse located Piracicaba, São Paulo State from September to December of 2001. It was a incomplete factorial set in radomized blocks with four replications, and the 13 combinations of nitrogen and sulphur were: 14 and 3.2; 14 and 32; 14 and 80; 126 and 12.8; 126 and 64; 210 and 3.2; 210 and 32; 210 and 80; 336 and 12.8; 336 and 64; 462 and 3.2; 462 and 32; 462 and $80 \mathrm{mg} \mathrm{L}{ }^{-1}$. Forage grass was harvested twice and in each one plant tops were separated in emergent leaves, lamina of recently expanded leaves, lamina of mature leaves and culms plus sheaths. After the second harvest roots were taken from the substrate and had the lenght and surface determined. The results showed significant interaction between nitrogen and sulphur rates for the number of total tillers, number of total expanded 
leaves, chlorophyll concentration (SPAD), leaf area, plant tops dry weight, nitrogen concentration in emergent leaves and in the roots, and sulphur concentration and $\mathrm{N}: \mathrm{S}$ ratio in emergent leaves, lamina of recently expanded leaves and in lamina of mature leaves in the Marandu grass at one or both harvests. Significant interaction between nitrogen and sulphur rates in the first harvest in the dry matter yield of the top parts. It was not significant either the interaction between nitrogen and sulphur rates or nitrogen and sulphur rate. Maximum nitrogen concentration (31.6 $\left.\mathrm{g} \mathrm{kg}^{-1}\right)$ was found in emergent leaves at the nitrogen rate of $462 \mathrm{mg} \mathrm{L}^{-1}$, in the first harvest. Sulphur concentration was maximum in the culms plus sheaths $\left(2.8 \mathrm{~g} \mathrm{~kg}^{-1}\right)$ on nitrogen rate of $14 \mathrm{mg} \mathrm{L}^{-1}$ at the second harvest. The $\mathrm{N}: \mathrm{S}$ ratio in the lamina of recently expanded leaves ranged from 2.8:1 to 37.2:1, with the minimum value observed with the very low nitrogen supply and the maximum with high nitrogen rate combined with low sulphur availability. There is a need of sulphur supply when nitrogen is made highly available to Marandu grass. 


\section{INTRODUÇÃO}

Atualmente no Brasil as pastagens são a principal fonte de alimentação para os ruminantes e entre elas destacam-se aquelas formadas com forrageiras do gênero Brachiaria, que constituem a maior parte das áreas destinadas ao pastejo. As espécies Brachiaria decumbens Stapf. e Brachiaria brizantha Stapf. cv. Marandu são as mais cultivadas no País e predominam amplamente no Brasil Central.

A Brachiaria brizantha é uma gramínea muito difundida em regiões mais ou menos úmidas, tendo grande capacidade de adaptação edafo-climática e boa resistência à seca e à cigarrinha. A espécie é apropriada para o pastejo, particularmente com bovinos de corte. Nas condições brasileiras, está comprovado que é possível melhor explorar técnica e economicamente a capacidade produtiva dessa forrageira.

A baixa disponibilidade de nutrientes na exploração da pastagem é seguramente um dos principais fatores que interfere tanto no nível de produtividade como na qualidade da forrageira. Assim, o fornecimento dos nutrientes em adequadas quantidade e proporção, assume importância fundamental no processo produtivo das pastagens.

$\mathrm{O}$ uso de fertilizantes concentrados, que não possuem enxofre em sua composição, tem gerado um grande problema nas condições brasileiras, cujos solos tem mostrado baixa disponibilidade de enxofre.

A deficiência de enxofre, demonstrada por apreciável número de culturas, acaba interferindo na quantidade absorvida de nitrogênio e, como conseqüência induz a planta a desenvolver uma deficiência de nitrogênio que, em muitos casos, acaba mascarando a deficiência de enxofre. 
Nesse contexto se insere a importância de estudos relativos ao suprimento desses dois nutrientes para a Brachiaria brizantha cv. Marandu, particularmente com a combinação de doses de nitrogênio e de enxofre.

O presente trabalho teve como objetivo avaliar as respostas da Brachiaria brizantha Stapf. cv. Marandu, cultivada em solução nutritiva, a combinações de doses de nitrogênio e enxofre quanto à emissão de perfilhos e de folhas pelas plantas; à estimativa do teor de clorofila (unidades SPAD); à área foliar; à produção de massa seca da planta (parte aérea e raízes); à atividade da redutase do nitrato; a sintomatologia de carência do nitrogênio e do enxofre; às concentrações de nitrogênio e de enxofre nas folhas emergentes, nas lâminas de folhas recém-expandidas, nas lâminas de folhas maduras, nos colmos+bainhas e nas raízes; à relação N:S e às concentrações de fósforo, potássio, cálcio e magnésio nas lâminas de folhas recém-expandidas. 


\section{REVISÃO DE LITERATURA}

\subsection{Brachiaria brizantha Stapf. cv. Marandu}

No Brasil aproximadamente 78 milhões de hectares são ocupados por pastagens naturais e 99,7 milhões de hectares são de pastagens plantadas. A região sudeste do país é responsável por cerca de 19,8 milhões de hectares de pastagens naturais e 12,1 milhões de hectares de pastagens plantadas, e desta área aproximadamente $40 \%$ é composto por Brachiaria brizantha.

A Brachiaria brizantha é originária de uma região vulcânica da África, onde os solos geralmente apresentam bons níveis de fertilidade, com precipitação pluvial anual ao redor de $700 \mathrm{~mm}$ e cerca de 8 meses de seca no inverno. É uma planta recomendada como alternativa para cerrados de média a boa fertilidade, face a alta produção de forragem, persistência, boa capacidade de rebrota, tolerância ao frio, à seca, ao fogo e a resistência ao ataque de cigarrinhas. A produção média anual é de $4 \mathrm{Mg}$ a $8 \mathrm{Mg} \mathrm{ha}^{-1} \mathrm{de}$ massa seca e pode chegar a $20 \mathrm{Mg} \mathrm{ha}^{-1}$ (Alcântara \& Bufarah, 1992).

O nome Marandu (que significa novidade no idioma tupi-guarani) foi dado a um ecótipo de Brachiaria brizantha estudado e liberado pelo Centro Nacional de Pesquisa de Gado de Corte (CNPGC) em conjunto com o Centro de Pesquisa Agropecuária dos Cerrados (CPAC), em 1983-1984. Trata-se de uma planta cespitosa, muito robusta que pode atingir, em livre crescimento, de 1,5 a 2,5 m de altura, apresenta colmos iniciais prostrados, mas produz perfilhos predominantemente eretos, rizomas muito curtos e encurvados, bainhas pilosas com cílios nas margens, geralmente mais longas que os entrenós, escondendo os nós, o que confere a impressão de haver densa pilosidade nos colmos vegetativos (Nunes et al., 1985). 


\subsection{Nitrogênio}

O nitrogênio é absorvido pelas plantas preferencialmente na forma de nitrato. No entanto, em condições de equilíbrio entre o nitrato e o amônio a absorção de amônio passa a ter maior expressão, pois a redução do nitrato a amônia para que o nitrogênio possa ser incorporado às cadeias carbônicas requer gasto de energia, dispêndio esse que não ocorre com a absorção do amônio.

O nitrogênio uma vez absorvido pela planta na forma de nitrato, é reduzido à forma amoniacal e combinado nas cadeias orgânicas da planta, formando glutamina e, a partir dela, os outros aminoácidos. Esses são as unidades básicas na formação de proteínas, as quais participam nos processos metabólicos das plantas, tendo papel funcional e estrutural (Marschner, 1997).

O nitrogênio é essencial para as plantas, pois possui função estrutural em moléculas de aminoácidos, proteínas, enzimas, coenzimas, vitaminas e pigmentos, faz parte de processos como absorção iônica, fotossíntese e respiração, e também estimula o crescimento de raízes (Malavolta, 1980). É encontrado no protoplasma das células, combinado com outros elementos fundamentais, sob a forma de substâncias orgânicas nitrogenadas (Marschner, 1997).

\subsubsection{Fornecimento de nitrogênio e produção de gramíneas forrageiras}

Machado (1974), abordando a influência do fornecimento de nutrientes para o vigor do crescimento e a produção da planta forrageira, ressaltou que o nitrogênio é consumido rapidamente pela planta em crescimento e exerce um efeito débil, senão nulo, na planta que rebrotará depois que aquela consumidora da quase totalidade do nitrogênio tenha sido cortada.

Pesquisando os efeitos das adubações nitrogenada e fosfatada em capim-Colonião (Panicum maximum), na formação e em pasto estabelecido, Monteiro \& Werner (1977) observaram que o requerimento de nitrogênio é maior após o desenvolvimento inicial da gramínea, incrementando a produção de massa seca, bem 
como a concentração e a produção de proteína bruta. Nesse sentido, também Werner et al. (1967) verificaram que, à exceção da adubação fosfatada, a falta de adubação nitrogenada foi a que mais influenciou no crescimento do capim-Colonião, limitando a produção de massa seca e o número de perfilhos.

Boin (1986) relatou que a produção de massa seca das gramíneas apresenta comportamento normalmente linear, variando com a freqüência de cortes e com as condições do solo e clima, em resposta à adubação nitrogenada.

As limitações nutricionais da Brachiaria decumbens foram estudadas em casa-de- vegetação por Ferrari Neto (1991), que constatou serem os elementos mais limitantes para a produção de massa seca, em ordem decrescente, nitrogênio, fósforo, potássio e enxofre. Neste sentido também, Faquin et al. (1995), pesquisando as limitações nutricionais para gramíneas forrageiras, observaram que na Brachiaria brizantha e no Andropogon gayanus os tratamentos que mais limitaram o crescimento das plantas foram omissão de nitrogênio, fósforo e potássio.

$\mathrm{O}$ conhecimento da influência do nitrogênio em épocas de crescimento e comportamento produtivo da Brachiaria brizantha cv. Marandu é de grande importância para assegurar uma exploração mais adequada de sua potencialidade, possibilitando maior produção por animal e por unidade de área (Ruggieri et al., 1994).

Os efeitos das fontes e doses de nitrogênio e as práticas de manejo na produção e qualidade da forragem de azevém anual ( Lolium multiflorum) foram estudadas por Alvim \& Moojen (1995) e permitiram concluir que incrementos nas doses de nitrogênio provocaram aumentos nas produções de massa seca, porém causaram a diminuição da eficiência e da recuperação do nitrogênio.

Entre os macronutrientes, o nitrogênio é o responsável pelo alcance da máxima produtividade por uma planta forrageira, pois permite, estando todos os outros nutrientes em quantidades adequadas, que a planta desenvolva o seu potencial de produtividade. A adubação nitrogenada estimula mais rapidamente o crescimento das forrageiras, sendo possível colheitas mais freqüentes de forragem mais digestível (Ribeiro, 1995).

Ribeiro (1995) observou que o rendimento forrageiro do capim-Elefante (Pennisetum purpureum)variou de 9317 a $14217 \mathrm{~kg} \mathrm{ha}^{-1}$ e de 7993 a $13660 \mathrm{~kg} \mathrm{ha}^{-1}$ de 
massa seca, com o aumento das doses de nitrogênio (0 a $\left.100 \mathrm{~kg} \mathrm{ha}^{-1}\right)$, quando as plantas foram cortadas ao atingirem 80 a $120 \mathrm{~cm}$ de altura, respectivamente.

Corrêa (1996), estudando os efeitos das doses de nitrogênio em aspectos produtivos e bioquímicos de três capins da espécie Panicum maximum, observou que o acréscimo das doses de nitrogênio na solução nutritiva proporcionou aumento na produção de massa seca e no perfilhamento desses capins.

Em estudo realizado em casa-de-vegetação com o objetivo de avaliar a produção e nutrição do capim-Marandu, em função da adubação nitrogenada e estádios de crescimento, Abreu \& Monteiro (1999) observaram que as produções de massa seca da parte aérea do capim-Marandu (Brachiaria brizantha), avaliadas aos 14, 28 e 42 dias do crescimento inicial, variavam significativamente com as doses de nitrogênio e de acordo com o ajuste das equações as máximas produções foram obtidas nas doses de nitrogênio de 140,152 e $190 \mathrm{mg} \mathrm{kg}^{-1}$ de solo.

$\mathrm{O}$ efeito das doses de nitrogênio em gramíneas do gênero Cynodon foi estudado por Mendes (2000), que concluiu ser a adubação nitrogenada promotora de aumentos nas produções de massa seca e no rendimento e concentração de proteína bruta das gramíneas. Respostas semelhantes foram obtidas por Ribeiro (2000) ao estudar o rendimento e o valor nutritivo do capim-Tifton 85 (Cynodon $\mathrm{sp}$ ) sob doses de nitrogênio e idades de rebrota, concluindo que houve aumento acentuado no rendimento forrageiro com as doses de nitrogênio e a extensão do intervalo de cortes.

Estudando a produção e a qualidade do capim-Tanzânia (Panicum maximum) estabelecido com milheto sob três doses de nitrogênio (60, 120 e $180 \mathrm{~kg} \mathrm{ha}^{-1}$ ), Barros (2000) relatou que houve efeito significativo das doses de nitrogênio na produção de massa seca do capim, ocorrendo aumento linear da produção de massa seca do capim verificando aumento de $31,1 \mathrm{~kg}$ na produção de massa seca para cada quilograma de nitrogênio aplicado. 


\subsubsection{Fornecimento de nitrogênio e concentração de nitrogênio em capins}

Quando uma dose muito baixa de fertilizante nitrogenado é aplicada para uma gramínea que está seriamente deficiente em nitrogênio, geralmente ocorre aumento na produção dessa gramínea, mas verifica-se pouca ou nenhuma mudança na concentração de nitrogênio. Entretanto, quando uma dose elevada de nitrogênio é aplicada, tanto a produção quanto a concentração do nutriente aumentam até a produção alcançar o máximo. Ás vezes quando uma baixa dose de nitrogênio é aplicada (50 a $100 \mathrm{~kg} \mathrm{ha}^{-1}$ ) numa pastagem deficiente, o aumento de produção é associado a um pequeno decréscimo na concentração de nitrogênio na planta. $\mathrm{O}$ efeito do fertilizante nitrogenado na concentração de nitrogênio da planta é influenciado pelo intervalo entre a aplicação e a amostragem, sendo que, em boas condições de crescimento, os intervalos menores apresentam concentração maior (Whitehead,1995).

Abreu \& Monteiro (1999), em estudo com doses de nitrogênio no capim-Marandu, observaram que a concentração de nitrogênio na massa seca das lâminas de folhas recém-expandidas obtida em três estádios de crescimento variou significativamente com as doses de nitrogênio, sendo observado que aos 14 dias o nitrogênio em $290 \mathrm{mg} \mathrm{kg}^{-1}$ proporcionou a máxima concentração $\left(40 \mathrm{~g} \mathrm{~kg}^{-1}\right)$. Aos $28 \mathrm{e}$ 42 dias as doses para a máxima concentração de nitrogênio seriam de 566 e $524 \mathrm{mg} \mathrm{kg}^{-1}$, associadas às concentrações de 47 e $20 \mathrm{~g} \mathrm{~kg}^{-1}$.

Doses de nitrogênio utilizadas na solução nutritiva proporcionaram aumento na concentração de nitrogênio total da massa seca da parte aérea e das raízes e na área foliar do Panicum maximum cv. Mombaça (Manarin, 2000). Ocorreu também aumento na atividade da enzima redutase do nitrato nas folhas desse capim, em função do incremento nas doses de nitrogênio na solução nutritiva. Neste mesmo sentido, Braga (2001) observou que a concentração de nitrogênio no capim-Mombaça (Panicum maximum), aumentou com a aplicação de doses do fertilizante nitrogenado. 


\subsection{Enxofre}

O enxofre é um macronutriente, que nos vegetais participa da síntese de aminoácidos sulfurados (metionina, cisteína e cistina), proteínas, inclusive enzimas, e também é componente da coenzima A (CoA), participante do metabolismo de carboidratos e lipídeos (Haag, 1984). Nos animais, é constituinte de proteínas, vitaminas e cartilagens (Guedes at al., 2000). Segundo Malavolta (1980), o enxofre está envolvido na formação da clorofila, na síntese de vitaminas como tiamina e biotina, e faz parte da ferrodoxina, molécula responsável pela transferência de elétrons e que atua na fotossíntese, na fixação de nitrogênio atmosférico e na redução de compostos oxidados.

Altas doses de enxofre podem afetar a absorção de nutrientes pela presença de íons acompanhantes e/ou pelos efeitos interiônicos que alteram a entrada de nutrientes na planta (Malavolta, 1980).

Plantas deficientes em enxofre têm interrompida a sua síntese de proteínas já que esse elemento participa de aminoácidos essenciais à planta e com isto o crescimento é retardado (Raij, 1991).

O enxofre é um elemento pouco móvel na planta e, assim os pontos de crescimento recentes sofrem primeiro quando as concentrações de enxofre não são adequadas para atingir a demanda da cultura (Lopes, 1998).

As proteínas são os compostos onde a maior parte de enxofre (e de nitrogênio) se incorpora. Em média, há cerca de 34 átomos de nitrogênio para cada átomo de enxofre nas proteínas. A concentração de enxofre nas proteínas é de $1 \mathrm{~g} \mathrm{~kg}^{-1}$ e a de nitrogênio é quinze vezes mais elevada (Barros, 2000).

\subsubsection{Fornecimento de enxofre e produção de gramíneas forrageiras}

Werner et al. (1967) observaram aumento significativo na produção de massa seca quando empregaram enxofre em $40 \mathrm{~kg} \mathrm{ha}^{-1}$ numa adubação completa do capimColonião. Os efeitos das doses e fontes de enxofre no capim-Colonião foram estudados por Malavolta et al. (1984), que verificaram no primeiro e segundo cortes haver efeito 
favorável ao enxofre adicionado, sendo observada redução na produção de massa seca do segundo para o terceiro corte, sugerindo o esgotamento dos adubos empregados.

Ferrari Neto (1991) constatou que, em condições de omissão de enxofre, os capins Braquiária (Brachiaria decumbens) e Colonião apresentaram redução de 30 a $41 \%$ na produção de massa seca da parte aérea. Santos (1997) também relatou limitação na produção de massa seca do capim-Braquiária em condições de baixa disponibilidade de enxofre.

Hoffman (1992), estudando a nutrição e o crescimento do capim-Braquiária e do capim-Colonião sob influência das aplicações de enxofre em Latossolo da região noroeste do Paraná, verificou que a produção de massa seca da parte aérea em ambas as espécies no primeiro corte foi maior que na rebrota, sendo a resposta da Braquiária maior em relação ao Colonião. Menores produções de massa seca foram observadas no segundo corte, principalmente nas doses mais elevadas, sendo justificada em parte por uma decapitação mais intensa de perfilhos por ocasião do primeiro corte.

Marques et al. (1995) observaram que a omissão de enxofre não interferiu no rendimento total de massa seca da parte aérea da Brachiaria brizantha quando cultivada na microregião Campos da Mantiqueira - MG. Entretanto Monteiro et al. (1995) observaram, nesta mesma espécie, reduções significativas na produção de massa seca e na altura de plantas no tratamento em que se omitiu enxofre, quando comparado com o tratamento completo.

Santos (1997) observou que o incremento nas doses de enxofre em solução nutritiva proporcionou aumentos na produção de massa seca da parte aérea e das raízes do capim-Braquiária, e que o número de perfilhos não sofreu influência das doses de enxofre no primeiro crescimento, mas foi incrementado no segundo crescimento (da dose de enxofre de 64 para $80 \mathrm{mg} \mathrm{L}^{-1}$ ). Observando que no primeiro crescimento a forrageira apresentou um incremento na produção de massa seca da parte aérea de 19\%, considerando desde a condição de omissão do nutriente até a de máxima produção, e no segundo crescimento o incremento foi de $48 \%$ para as mesmas condições avaliadas no primeiro crescimento. 
Cunha et al. (2001), testando os efeitos das doses de nitrogênio e enxofre na produção e qualidade da forragem de campo natural de Planossolo no Rio Grande do Sul, observaram que o campo natural de Planossolo responde positivamente em termos de produtividade de massa seca, quando adubado com nitrogênio ou enxofre, no início da primavera. Observaram também que a produtividade de massa seca atinge o ponto máximo na dose de enxofre de $33,4 \mathrm{~kg} \mathrm{ha}^{-1}$.

\subsubsection{Fornecimento de enxofre e concentração de enxofre em capins}

Estabelecendo as faixas críticas de enxofre na massa seca do capim-Braquiária para 80 e $90 \%$ da produção máxima, Hoffman (1992) encontrou os valores $0,9 \mathrm{~g} \mathrm{~kg}^{-1} \mathrm{de}$ enxofre (80\% da produção máxima) no primeiro crescimento e $1,1 \mathrm{~g} \mathrm{~kg}^{-1}$ de enxofre (90\% da produção máxima) no segundo crescimento. Hoffman (1992) ressaltou que o valor mais alto no segundo crescimento foi devido ao efeito da concentração pelos menores valores de massa seca produzidas em relação ao primeiro corte.

Ferrari Júnior et al. (1994), pesquisando a produção de feno da Brachiaria decumbens e Brachiaria brizantha cv. Marandu sob três frequiências de cortes, observaram que a concentração de enxofre apresentava valores médios de $1,2 \mathrm{~g} \mathrm{~kg}^{-1} \mathrm{e}$ não diferia entre essas gramíneas.

Estudando os efeitos da adubação nitrogenada na produção e composição da Brachiaria ruziziensis, Andrade et al. (1996) observaram que os valores de enxofre equivaliam a $1 \mathrm{~g} \mathrm{~kg}^{-1}$ nos tratamentos sem nitrogênio e a $1,4 \mathrm{~g} \mathrm{~kg}^{-1}$ nos tratamentos com nitrogênio.

Colozza (1998), estudando o capim-Aruana (Panicum maximum), observou que em ambas as amostragens a concentração de enxofre foi mais elevada nas lâminas de folhas maduras, efeito este que pode ser creditado ao fato do enxofre ser praticamente imóvel na planta. Em outro estudo com capim-Mombaça, Colozza (1998) verificou que a concentração de enxofre diminuiu nos colmos mais bainhas no primeiro e segundo crescimentos e justificou isto com o fato de que nestas partes da planta foram encontradas as mais altas concentrações de nitrato . 
Santos (1997), ao discutir as concentrações de enxofre na massa seca da parte aérea do capim-Braquiária em função da aplicação de nitrogênio, inferiu que essa redução observada nas concentrações poderia ser devido ao efeito de diluição da concentração com o aumento da produção de massa seca.

A resposta do capim-Mombaça a doses de nitrogênio e aos intervalos de corte foi estudada por Braga (2001) e observou que as concentrações de enxofre do capimMombaça sofreram influência das doses de nitrogênio aplicadas. A dose de $250 \mathrm{~kg} \mathrm{ha}^{-1}$ foi a que ocasionou mais baixa concentração de enxofre $\left(1,39 \mathrm{~g} \mathrm{~kg}^{-1}\right)$ enquanto que as plantas adubadas com nitrogênio de 0 e $500 \mathrm{~kg} \mathrm{ha}^{-1}$ apresentaram concentração de 1,71 e $1,64 \mathrm{~g} \mathrm{~kg}^{-1}$, de enxofre, respectivamente.

\subsection{Relação nitrogênio: enxofre}

Na produção do pasto, a quantidade de enxofre requerida para o crescimento e funcionamento normal das atividades metabólicas das gramíneas é consideravelmente menor que a demanda de nitrogênio e o déficit de enxofre não tem sido relatado freqüentemente tal como o de nitrogênio. $\quad \mathrm{Na}$ presença de ânions mais móveis tais como cloreto e nitrato tem-se observado menor absorção de sulfato. Por esse motivo pode-se algumas vezes ser útil demonstrar que o abastecimento de enxofre tem sido adequado quando as gramíneas tem crescido em altas taxas de aplicação de nitrogênio e enxofre e os resultados indicam a interferência de alguns outros fatores nutricionais no crescimento (Dijkshoorn \& Lampe, 1960).

Em média, proteínas vegetais tem sido encontradas contendo, aproximadamente, enxofre em $10 \mathrm{~g} \mathrm{~kg}^{-1}$ e nitrogênio em $170 \mathrm{~g} \mathrm{~kg}^{-1}$. Esses valores após serem divididos pelo peso atômico, fornecem uma taxa atômica de enxofre e nitrogênio de $(\mathrm{S} / \mathrm{N})_{\mathrm{p}}=0,025$ ou $\mathrm{S} / \mathrm{N}=0,0588$. Das considerações anteriores seguem a taxa atômica do $\mathrm{S}$ orgânico para $\mathrm{N}$ orgânico no total de massa de gramíneas: $(\mathrm{S} / \mathrm{N})_{0}$ igual $(\mathrm{S} / \mathrm{N})_{\mathrm{p}}=0,025$, a forma orgânica desses elementos presentes nas substâncias proteicas. Qualquer falta de enxofre em relação ao nitrogênio inibiria a formação de proteínas, caso contrário a relação S/N cairia abaixo do valor $(\mathrm{S} / \mathrm{N})_{\mathrm{p}}$ específico para substâncias proteicas. Além disso qualquer 
sulfato absorvido em excesso para a produção ficaria inutilizado (Dijkshoorn \& Lampe, 1960).

O uso de adubos portadores de enxofre está diretamente relacionado com a utilização eficiente do nitrogênio, uma vez que além da conhecida influência da lei do mínimo na produtividade agrícola, o nitrogênio e o enxofre exercem funções tão relacionadas na vida da planta, que muitas vezes é possível definir-se o estado nutricional com base na relação entre as concentrações desses dois elementos na massa seca (Vitti, 1986).

Malavolta (1986), em discussão com relação à adubação sulfatada (doses e relação $\mathrm{N}: \mathrm{S}$ ), relatou que um ponto importante a ser mencionado nas possíveis causas do incremento da necessidade de enxofre das culturas e do aumento das respostas a adição de enxofre pelas mesmas é a relação N:S na adubação. Acrescentou que em se incrementando a dose de nitrogênio na adubação é necessário aumentar a dose de enxofre correspondentemente, a fim de se garantir o equilíbrio desses nutrientes dentro da planta.

Monteiro \& Carriel (1987) reportaram que a aplicação de enxofre de $40 \mathrm{~kg} \mathrm{ha}^{-1}$ num solo Podzólico resultou na relação N:S de 13,7:1 e na concentração de enxofre de $0,8 \mathrm{~g} \mathrm{~kg}^{-1}$ no capim-Colonião, por ocasião do segundo crescimento.

Werner \& Monteiro (1988) relataram que pastagens exclusivas de gramíneas não adubadas com nitrogênio e fósforo mostram pouca ou nenhuma resposta ao enxofre e citaram que a concentração do enxofre na planta acima da requerida para a síntese de proteínas resulta em acumulação do enxofre no tecido vegetal, especialmente na forma de sulfato.

A alta disponibilidade de nitrogênio requer aplicação mais elevada de enxofre, uma vez que este nutriente é importante no metabolismo do nitrogênio e na síntese de proteína (Werner \& Monteiro, 1988). Consequentemente, a importância do equilíbrio entre as quantidades de nitrogênio e enxofre no solo e na planta é refletida no crescimento e no estado nutricional do vegetal. As pastagens com deficiência de nitrogênio apresentam baixas respostas à aplicação de enxofre (Santos, 1997). 
Esta estreita relação entre a necessidade de enxofre e às quantidades de nitrogênio disponíveis para as culturas. não se constitui em surpresa, uma vez que ambos são constituintes das proteínas e estão associados com a formação de clorofila. Pesquisadores têm sugerido com freqüência que a relação $\mathrm{N}: \mathrm{S}$ (N total para $\mathrm{S}$ total) nas plantas é um bom instrumento de diagnose para determinar a deficiência de enxofre. Relações de 7:1, 10:1, 11:1, 15:1 e outras têm sido consideradas (Lopes, 1998). Neste sentido, Werner \& Monteiro (1988), discorrendo sobre as respostas das pastagens a aplicação de enxofre, demostraram através de vários trabalhos que a relação $\mathrm{N}: \mathrm{S}$ nas plantas forrageiras pode variar de 12:1 a 19:1, dependendo da espécie e do suprimento de enxofre.

Quando a planta atinge a maturidade, a relação N:S tende a se estabilizar em 14:1 nas gramíneas, sendo que uma relação $\mathrm{N}: \mathrm{S}$ de 20:1 revelaria severa deficiência de enxofre. A deficiência de enxofre interfere no aproveitamento de nitrogênio, restringindo o crescimento da planta, haja visto, que uma das principais funções do enxofre é a conversão do nitrogênio não protéico em protéico, seja ele absorvido do solo, ou da atmosfera via sistema simbiótico das leguminosas (Costa, 1999).

Ao analisar as relações observadas em um experimento onde se estudava a influência de épocas e doses de adubação nitrogenada na produção estacional de dois capins, Costa (1999) verificou que as relações $\mathrm{N}: \mathrm{S}$ encontradas estavam abaixo de 12:1 a 15:1, intervalo este considerado adequado para gramíneas, de acordo com vários pesquisadores.

A influência da aplicação de gesso na produção de massa seca, na relação nitrogênio:enxofre e nas concentrações de enxofre, nitrogênio e nitrato em Brachiaria decumbens foram estudadas por Guedes et al. (2000), que não verificaram alteração na concentração de nitrogênio na planta, indicando que a adubação sulfatada não interferiu na absorção de nitrogênio. A fonte de nitrogênio utilizada foi uréia e os autores justificaram que os baixos valores de concentração de nitrogênio encontrados no primeiro crescimento, eram resultantes em parte das condições da adubação nitrogenada, que favoreceram a lixiviação e a volatilização. 
Barros (2000) observou efeito significativo das doses de nitrogênio nas concentrações de enxofre na massa seca do capim-Tanzânia, ocorrendo aumento linear de enxofre em resposta à adubação nitrogenada, com acréscimo de $0,002 \mathrm{~g} \mathrm{~kg}^{-1}$ para cada quilograma de nitrogênio aplicado.

Mattos (2001), avaliando pastagens de capim-Braquiária degradadas e sua recuperação com suprimento de nitrogênio e enxofre, encontrou, no primeiro crescimento na dose de nitrogênio de $192 \mathrm{mg} \mathrm{dm}^{-3}$ e de enxofre de $30 \mathrm{mg} \mathrm{dm}^{-3}$, a mais alta produção de massa seca. Na dose de enxofre de $60 \mathrm{mg} \mathrm{dm}^{-3}$ ocorreu produção similar, porém em presença de mais baixa dose de nitrogênio. Na não aplicação de enxofre houve redução de $23 \%$ na produção de massa seca. No segundo crescimento a aplicação de doses de nitrogênio e enxofre ajustou-se ao modelo linear de regressão, mostrando que a máxima produção de massa seca da parte aérea ocorreria em doses de nitrogênio mais elevadas do que as utilizadas. A combinação entre a máxima dose de nitrogênio e enxofre elevou em $22 \%$ a produção de massa seca em relação a mesma dose de nitrogênio sem aplicação de enxofre. Houve efeito significativo das doses de enxofre dentro da dose de $200 \mathrm{mg} \mathrm{dm}^{-3}$ de nitrogênio, e esse efeito foi ajustado a equação de segundo grau. No terceiro crescimento a máxima produção de massa seca foi alcançada com aplicação de nitrogênio de $141 \mathrm{mg} \mathrm{dm}^{-3}$.

A relação N:S foi discutida por Braga (2001) quando estudou a resposta do capim-Mombaça a doses de nitrogênio e intervalos de corte, tendo ressaltado que a relação $\mathrm{N}: \mathrm{S}$ respondeu de forma quadrática à aplicação de nitrogênio, atingindo seu ponto máximo na dose de nitrogênio de $380 \mathrm{~kg} \mathrm{ha}^{-1}$. Com o aumento da dose de nitrogênio a relação $\mathrm{N}: \mathrm{S}$ elevou-se devido a maior concentração de nitrogênio na planta nesta condição e também à queda da concentração de enxofre. A relação N:S tida como adequada de 15:1 estaria mais próxima da dose mais elevada de nitrogênio (500 $\mathrm{kg} \mathrm{ha}^{-1}$ ) que associou a elevação da concentração foliar de nitrogênio com a redução da concentração de enxofre (por diluição). 


\subsection{Nitrogênio e enxofre no perfilhamento e taxa de aparecimento de folhas}

Em gramíneas, cada folha (exceto aquela imediatamente abaixo da inflorescência) pode ter um perfilho brotando em uma gema axilar, e sempre que o suprimento de nutriente é adequado e a competição por espaço não é severa, a maior parte destas gemas desenvolvem-se formando os perfilhos. Quando o nitrogênio está deficiente, o desenvolvimento de perfilhos é inibido, mas aumentando-se o suprimento de nitrogênio para as plantas que crescem individualmente, aumenta-se o número de perfilhos por planta (Langer, 1963).

Ferrari Neto (1991), estudando as limitações nutricionais para o capim-Colonião e o capim-Braquiária em Latossolo da região noroeste do Estado do Paraná, verificou que o perfilhamento sofreu redução drástica quando na ausência de nitrogênio e fósforo, e foram seguidos em menor intensidade pelo enxofre e potássio.

Corsi \& Nússio (1992), discorrendo sobre o manejo do capim-Elefante quanto à correção e adubação do solo apontaram que a recuperação do nitrogênio é melhorada quando a planta é capaz de aumentar o perfilhamento e a expansão das folhas.

As características de crescimento e produção de massa seca da Brachiaria brizantha cv. Marandu em função de doses de nitrogênio e regime de corte foram estudadas por Ruggieri et al. (1994), que observaram serem as doses de nitrogênio responsáveis pelo aumento da porcentagem de folhas e acrescentaram que este fato, de certa forma, poderia estar relacionado com as quantidades aplicadas do adubo nos três períodos de crescimento. Isto provavelmente pode ter influenciado positivamente na proporção de folhas, em relação às demais partes da planta, mesmo não resultando esses aumentos em superioridade nas produções de massa seca e de folhas. As doses de nitrogênio de 33 e $66 \mathrm{~kg} \mathrm{ha}^{-1}$ não influenciaram a densidade de perfilhos e a produção de folhas.

Para Nabinger \& Medeiros (1995) a disponibilidade de nitrogênio é o fator dominante que controla os processos de crescimento e desenvolvimento da planta, traduzido sobretudo pela maior rapidez de formação das gemas axilares e de iniciação dos perfilhos correspondentes, mas esta iniciação só se manifesta enquanto o índice de 
área foliar não passar de um valor crítico, alterando a quantidade de luz que chega às gemas mais tardias. Desta forma, os fatores do meio que podem ser favoráveis ao perfilhamento, quando a cobertura vegetal está pouco desenvolvida, podem ter efeito negativo quando a cobertura vegetal está bem desenvolvida porque o índice de área foliar aumenta e consequentemente a competição pela luz entre perfilhos. Um déficit de nitrogênio aumenta o número de gemas dormentes enquanto o nível de nutrição nitrogenada permite o máximo perfilhamento.

Segundo Cruz \& Boval (1996) a adubação nitrogenada afeta a expressão de variáveis morfogenéticas básicas das gramíneas, aumentando o elongamento foliar e a taxa de perfilhamento tendo um leve efeito sobre a taxa de aparecimento de folha. $\mathrm{O}$ tamanho final da lâmina foliar é fortemente aumentado pelo nitrogênio disponível.

A produção de tecido foliar pode ser analisada como resultado da interação de dois processos: (i) a produção de assimilados pela plantas individualmente resultantes da interceptação luminosa e fotossíntese, e (ii) o uso de assimilados por meristemas foliares para a produção de novos crescimentos foliares e, finalmente, para a expanssão foliar. Então, a taxa de expansão de novos tecidos foliares na planta pode ser considerada limitante para a produção ou uso de assimilados. O uso de assimilados pelos meristemas foliares é determinado diretamente pela temperatura, que dirige as taxas de divisão e expansão celular e cria uma demanda por carbono e nitrogênio para providenciar energia e material para expansão do tecido foliar (Lemaire \& Agnusdei, 1999).

A adubação nitrogenada deve ser realizada quando houver equilíbrio entre os nutrientes e na época das chuvas, parcelando a adubação com nitrogênio para aumentar a eficiência de utilização por parte da planta. Se a adubação é executada nesta época, ocorrerá aumento na produção de forragem a partir do aumento no número e no peso de perfilhos (Aguiar, 1998).

Colozza (1998), avaliando o capim-Mombaça adubado com doses de nitrogênio, observou que o número de perfilhos aumentou até a dose de nitrogênio de 149 e $168 \mathrm{mg} \mathrm{kg}^{-1}$ para o primeiro e segundo crescimentos, respectivamente. No primeiro crescimento as plantas sem adubação nitrogenada apresentaram em média três perfilhos 
por planta e na dose de nitrogênio de $60 \mathrm{mg} \mathrm{kg}^{-1}$ (dose em que houve o máximo perfilhamento) tiveram quatro perfilhos por planta, enquanto que no segundo corte as plantas sem adubação nitrogenada continuaram com três perfilhos por planta e ras doses de nitrogênio de 280 e $400 \mathrm{mg} \mathrm{kg}^{-1}$ (doses em que houve o máximo perfilhamento) ocorreram seis perfilhos por planta.

Santos \& Monteiro (1999), trabalhando com Brachiaria decumbens e doses de enxofre, observaram que o perfilhamento desta forrageira foi alterado significativamente pelas doses de enxofre apenas no segundo crescimento e que as doses de enxofre de 64 e $80 \mathrm{mg} \mathrm{L}^{-1}$ não diferiram entre si, mas tiveram número de perfilhos superior ao das doses mais baixas de enxofre. A diferença do número de perfilhos entre os dois crescimentos da forrageira pode ser devido ao melhor estabelecimento do sistema radicular existente no segundo crescimento da forrageira, promovendo maior absorção de nutrientes e maior acúmulo de assimilados pela fotossíntese e de energia necessária para estimular o número de gemas basais existentes.

O efeito de três doses de nitrogênio nas características do capim-Marandu após o corte de uniformização foi estudado por Alexandrino (2000), que concluiu haver, com o aumento da dose de nitrogênio, incremento linear nas taxas de aparecimento e alongamento foliar, no tamanho médio de folhas e na área foliar, proporcionando maior potencial de rebrotação após desfolhação, sendo que a taxa de alongamento foliar foi a característica que mais contribuiu para o aumento do tamanho médio de folhas.

Braga (2001), estudando a resposta do capim-Mombaça a doses de nitrogênio e intervalos de corte, relatou que houve efeito quadrático do nitrogênio no número de perfilhos, sendo que este aumento ocorreu somente até o ponto máximo na dose de $406 \mathrm{~kg} \mathrm{ha}^{-1}$.

O perfilhamento da Brachiaria decumbens foi estudado por Mattos (2001) que observou aumento no número total de perfilhos com o fornecimento de nitrogênio de 0 para $50 \mathrm{mg} \mathrm{dm}^{-3}$ e não variação de 50 a $200 \mathrm{mg} \mathrm{dm}^{-3}$. No segundo crescimento constatou resposta significativa para as doses de nitrogênio de $200 \mathrm{mg} \mathrm{dm}^{-3} \mathrm{e}$ de enxofre de $60 \mathrm{mg} \mathrm{dm}^{-3}$. No terceiro crescimento a resposta foi significativa para a dose de nitrogênio de $200 \mathrm{mg} \mathrm{dm}^{-3}$. 


\section{6 Área foliar}

A área foliar é um importante parâmetro para a análise de crescimento e desenvolvimento das plantas. Quanto maior a área foliar maior será a superficíe de exposição das folhas, e portanto maior a capacidade fotossintética da planta.

Mattos (2001), estudando a área foliar da Brachiaria decumbens em pastagem degradada suprida com nitrogênio e enxofre encontrou interação entre as doses de nitrogênio e as doses de enxofre, no primeiro e terceiro crescimentos. No primeiro crescimento verificou efeito significativo para as doses de nitrogênio $(50,100$ e $200 \mathrm{mg} \mathrm{dm}^{-3}$ ) dentro de cada uma das doses de enxofre (30 e $60 \mathrm{mg} \mathrm{dm}^{-3}$ ). Os pontos de máxima área foliar total dessa forrageira ocorreram com as doses de nitrogênio de 122, 125 e $220 \mathrm{mg} \mathrm{dm}^{-3}$ e entre as doses de enxofre de 0,30 e $60 \mathrm{mg} \mathrm{dm}^{-3}$, respectivamente. Constatou-se também significância para a aplicação de enxofre, dentro das doses de nitrogênio de 100 e $200 \mathrm{mg} \mathrm{dm}^{-3}$. No segundo crescimento houve efeito significativo para a aplicação de enxofre, dentro das doses de nitrogênio de 100 e $200 \mathrm{mg} \mathrm{dm}^{-3}$. No segundo crescimento verificou efeito significativo para as doses de nitrogênio, porém não para as doses de enxofre. No terceiro crescimento observou efeito significativo do nitrogênio dentro das doses de enxofre, segundo equação linear nas doses de enxofre de 0 e $60 \mathrm{mg} \mathrm{dm}^{-3}$ e quadrática na dose de enxofre de $30 \mathrm{mg} \mathrm{dm}^{-3}$.

Santos Júnior (2001), analisando a dinâmica de crescimento e nutrição do capimMarandu submetido a doses de nitrogênio, observou que tanto a produção de massa seca como de área foliar foram alteradas pelas doses de nitrogênio, ressaltando que essas duas variáveis seguiram modelo quadrático nas seis idades de crescimento estudadas.

\subsection{Redutase do nitrato}

A maior parte do nitrogênio é absorvido pelas plantas na forma de nitrato. Após a sua absorção, para que ele possa ser utilizado pelas plantas é necessário que seja reduzido a amônia, e então incorporado em composto orgânico. Essa passagem do nitrato a amônia é constituída por várias etapas, que ocorrem preferencialmente nas 
folhas, e entre essas destaca-se a redução do nitrato a nitrito, que é dependente da atividade da enzima redutase do nitrato.

Estudos têm sugerido que a transformação de nitrato até aminoácidos é controlada pela atividade da redutase do nitrato pelo fato de ser a primeira enzima no caminho metabólico. Essa enzima é relativamente instável tanto "in vivo" como "in vitro", e especialmente sensível quando submetida a condições extremas de disponibilidade de água e temperatura (Beevers \& Hageman, 1969).

O nitrogênio e o enxofre estão relacionados pela função do enxofre na ativação da enzima redutase do nitrato. A baixa atividade dessa enzima diminui os níveis de proteína solúvel, enquanto aumenta as concentrações de $\mathrm{N}^{-N_{3}}$ nos tecidos das plantas. Os altos níveis de $\mathrm{N}-\mathrm{NO}_{3}$ que são acumulados quando o enxofre é deficiente, podem tornar-se tóxicos para os animais que consomem forragens deficientes em enxofre (Lopes, 1998).

Em estudo relativo à diagnose nutricional e às respostas do capim-Braquiária a doses de nitrogênio e de enxofre, Santos (1997) relatou que o nitrogênio estimulou a atividade da redutase do nitrato, que a concentração de clorofila nas folhas da braquiária apresentou alta correlação com as doses de nitrogênio adicionadas e que o acúmulo de nitrogênio foi menor nas folhas emergentes e maior nos colmos mais bainhas no primeiro crescimento e nas lâminas de folhas recém-expandidas no segundo crescimento desse capim. Observou também que a atividade da redutase do nitrato e a concentração de clorofila nos dois crescimentos do capim-Braquiária foram estimulados pelas doses de enxofre na solução nutritiva e o acúmulo de enxofre foi menor nas folhas nãoexpandidas e maior nos colmos + bainhas, nos dois crescimentos.

\subsection{Estimativa do teor de clorofila através do valor SPAD}

Tem sido utilizada uma forma auxiliar para a avaliação da nutrição nitrogenada das culturas através do equipamento denominado clorofilômetro (SPAD 502), o qual determina indiretamente a concentração de clorofila nas folhas, pela leitura da reflectância do verde no comprimento de onda de aproximadamente $650 \mathrm{~nm}$. Essa 
concentração de clorofila está diretamente correlacionada com a concentração de nitrogênio nas folhas e, por conseguinte, com a nutrição e a produção vegetal. A relação entre valor SPAD e concentração de nitrogênio pode ser linear até que o nitrogênio não seja mais assimilado e seja acumulado na forma de nitrato, tendendo formar uma estabilização da intensidade de verde, de forma a refletir o acúmulo de nitrato (Abreu \& Monteiro, 1999).

Muitas pesquisas realizadas com a finalidade de relacionar o teor de clorofila determinado pelo clorofilômetro com a concentração de nitrogênio nas folhas de plantas anuais de interesse econômico têm demonstrado que essa determinação é promissora para avaliar o estado nutricional das plantas em relação ao nitrogênio. Entretanto o número de informações com gramíneas forrageiras tropicais é muito pequeno (Colozza et al., 2000).

Em estudo sobre o rendimento e diagnose foliar dos capins Aruana e Mombaça cultivado em Latossolo Vermelho-Amarelo adubado com doses de nitrogênio, Colozza (1998) encontrou os valores SPAD de 32,7 e 39,7 nas lâminas de folhas recémexpandidas, respectivamente no primeiro e segundo crescimentos do capim-Aruana. Para o capim-Mombaça observou que o valor SPAD aumentou linearmente com as doses de nitrogênio e as folhas recém - expandidas apresentaram o valor de 38,6 para ambos os cortes.

Os valores das leituras de SPAD nas lâminas de folhas recém - expandidas foram estudados por Abreu \& Monteiro (1999) no capim-Marandu e observaram que para as idades de 28 e 42 dias os valores de SPAD foram significativamente influenciados pelas doses de nitrogênio, sendo o máximo valor SPAD observado nas doses de nitrogênio de 205 e 314,5 mg L ${ }^{-1}$, respectivamente. A análise das equações de regressão obtidas demonstrou que aos 14, 28 e 42 dias de crescimento da forrageira, o valor SPAD variou entre 31, 18 e 14 para a não aplicação de nitrogênio e entre 51, 57 e 46 para a dose de nitrogênio relacionada ao máximo valor SPAD, tendo esses máximos valores correspondido às doses de 228, 239 e $302 \mathrm{mg} \mathrm{L}^{-1}$, respectivamente.

Colozza et al. (2000), estudando valores de SPAD no Panicum maximum cv. Aruana, verificaram que os valores de SPAD nas lâminas de folhas recém-expandidas, 
no primeiro corte e no segundo corte variaram significativamente com as doses de nitrogênio, sendo que para o primeiro corte o valor máximo de SPAD foi obtido na dose de nitrogênio de $255 \mathrm{mg} \mathrm{kg}^{-1}$ e para o segundo corte na dose de $374 \mathrm{mg} \mathrm{kg}^{-1}$.

A estimativa do teor de clorofila estudada por Mattos (2001) no capimBraquiária demonstrou interação entre as doses de nitrogênio e de enxofre. No primeiro crescimento o valor SPAD foi menor na ausência de adubação com enxofre, em presença da dose de nitrogênio de $200 \mathrm{mg} \mathrm{dm}^{-3}$. O mais alto valor SPAD ocorreu na dose de enxofre de $47 \mathrm{mg} \mathrm{dm}^{-3}$, com nitrogênio de $200 \mathrm{mg} \mathrm{dm}^{-3}$. No segundo crescimento foi observado efeito significativo das doses de nitrogênio, em presença de cada uma das doses de enxofre. As doses de enxofre, dentro de cada dose de nitrogênio, não apresentaram significância para o valor SPAD. No terceiro crescimento observou variação significativa em função do suprimento de nitrogênio, sendo a dose de nitrogênio de $140 \mathrm{mg} \mathrm{dm}^{-3}$ a que apresentou o máximo valor SPAD.

\subsection{Sistema radicular}

O sistema radicular é responsável pela sustentação da planta e pela absorção de água e nutrientes para suprir os processos metabólicos internos do vegetal. Um sistema radicular bem desenvolvido garante boa formação e sustentação da parte aérea e, como conseqüência, boa produção da planta.

A baixa disponibilidade de nitrogênio favorece o aumento da relação entre as raízes e a parte aérea, isto devido ao maior crescimento do sistema radicular em relação a parte aérea. Uma planta bem suprida de nirogênio possui sistema radicular com melhor desenvolvimento que uma planta deficiente em nitrogênio, isto porque os mecanismos envolvidos no crescimento do sistema radicular estão relacionados com o acúmulo de carboidratos na ausência de nitrogênio, tanto na parte aérea como nas raízes (Brouwer,1962).

Além dos aspectos fisiológicos, o sistema radicular das plantas cultivadas vem assumindo importante papel nos estudos das interações que ocorrem entre os solos, as plantas e outros organismos vivos. Assim, destacam-se os aspectos físicos, químicos e 
biológicos inerentes ao meio solo, favoráveis à distribuição de raízes (Crestana et al., 1994). Esses autores, avaliando a distribuição de raízes no solo, com o auxílio de processamento de imagens digitais, concluíram que os resultados foram animadores, indicando que o processamento de imagens no estudo do desenvolvimento radicular de plantas constitui ferramenta importante, relativamente simples e precisa.

Os efeitos dos fertilizantes nitrogenados na composição mineral das gramíneas dependem particularmente do suprimento individual dos elementos. Quando um elemento tem seu suprimento limitado, o aumento no crescimento da planta resultante da ação do nitrogênio, tende a diluir sua concentração na planta. Entretanto, quando existe um abundante suprimento do nutriente em questão, o efeito de diluição pode ser encoberto pelo aumento do consumo pela planta. $\mathrm{O}$ aumento do consumo de determinado nutriente ocorre com o aumento da atividade das raízes e/ou sob efeito sinergístico do nitrogênio com o nutriente (Whitehead,1995).

É grande a necessidade de abordagens criativas no estudo de sistemas radiculares. Além das dificuldades de observação e quantificação de raízes, elas constituem um sistema bastante complexo, composto de milhares de segmentos individuais, de diferentes classes morfológicas, fisiológicas e de desenvolvimento. $\mathrm{O}$ suprimento de água e nutrientes para as plantas depende das interações entre os complexos processos fisiológicos e celulares ocorrentes no sistema radicular, que resultam numa arquitetura específica ( habilidade da planta em adquirir os recursos do solo), e dos não menos complexos processos iônicos e de transporte ocorrentes no solo (disponibilidade dos recursos do solo às raízes), de acordo com Teruel et al. (2000). Um sistema radicular com elevado comprimento, superficíe e biomassa permite um maior contato com o solo, aumentando a eficiência na absorção de nutrientes (Santos Júnior, 2001).

Santos Junior(2001), estudando a dinâmica de crescimento e nutrição do capimMarandu submetido a doses de nitrogênio, observou que o comprimento radicular, dentro de cada idade de crescimento e em função das doses de nitrogênio, apresentou efeito significativo, seguindo modelo linear de regressão na idade de 56 dias de crescimento e quadrático nas demais idades, e os máximos comprimentos radiculares 
corresponderam às doses de nitrogênio de 207, 199, 199, 236 e $294 \mathrm{mg} \mathrm{L}^{-1}$, nas idades de crescimento de 21, 28, 35, 42 e 49 dias, respectivamente.

A superfície total de raízes do capim-Mombaça foi avaliada por Lavres Junior (2001) que verificou, através da equação polinomial de regressão, que a dose de nitrogênio necessária para a máxima superfície radicular das raízes seria de $814 \mathrm{mg} \mathrm{L}^{-1}$. Ressaltou ainda a importância da maior necessidade de nitrogênio para o crescimento do sistema radicular.

Para a superfície radicular Santos Junior (2001) observou que as doses de nitrogênio, dentro de cada idade de crescimento, alteraram significativamente a superfície do sistema radicular do capim-Marandu. Os máximos valores de superfície radicular do capim-Marandu corresponderam às doses de nitrogênio de 200, 195, 217, 259 e $312 \mathrm{mg} \mathrm{L}^{-1}$ na solução nutritiva, nas idades de crescimento de 21, 28, 35, 42 e 49 dias, respectivamente.

Lavres Junior (2001) constatou que para a obtenção do máximo comprimento total das raízes do capim-Mombaça seria necessário o fornecimento da dose de nitrogênio de $596 \mathrm{mg} \mathrm{L}^{-1}$ na solução nutritiva. $\mathrm{O}$ autor ressaltou também que o nitrogênio é o principal nutriente modulador das respostas para este atributo produtivo nestas plantas. 


\section{MATERIAL E MÉTODOS}

\subsection{Local, espécie forrageira e período do experimento}

O experimento foi conduzido numa casa-de-vegetação localizada no Departamento de Solos e Nutrição de Plantas da Escola Superior de Agricultura "Luiz de Queiroz"-USP, Câmpus de Piracicaba, Estado de São Paulo, cultivando-se a espécie forrageira Brachiaria brizantha Stapf. cultivar Marandu, no período de setembro a dezembro de 2001 (Figura 1).

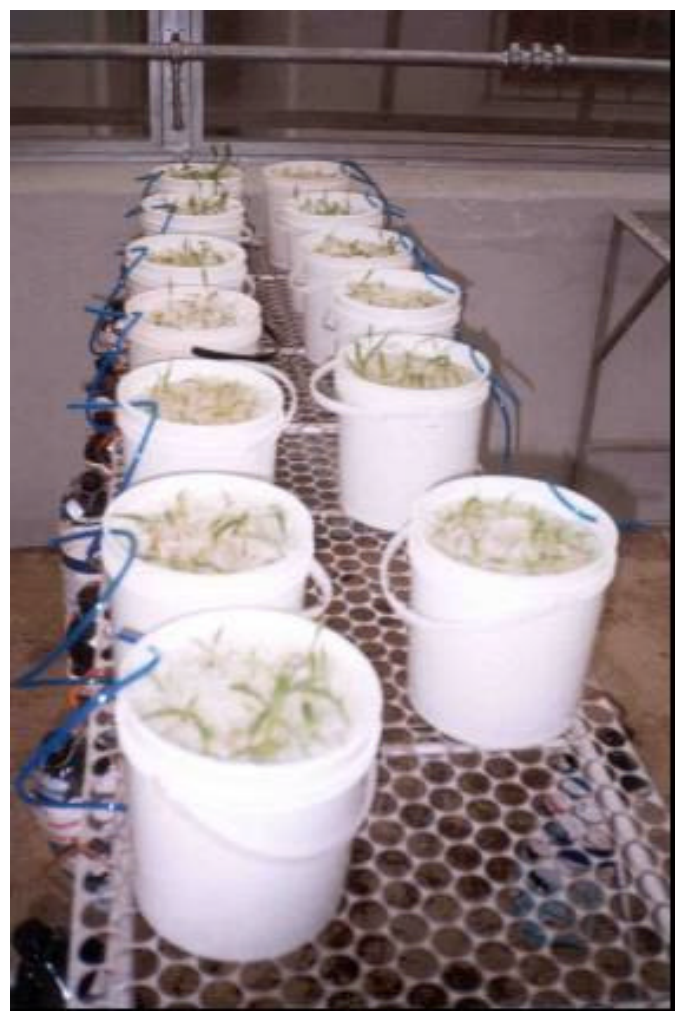

Figura 1- Vista parcial dos vasos experimentais dispostos na casa-de-vegetação. 


\subsection{Doses de nitrogênio e de enxofre, soluções nutritivas e delineamento experimental}

Foram testadas as combinações de doses de nitrogênio com doses de enxofre em solução nutritiva, utilizando-se vasos plásticos com capacidade de 3,6 L e tendo sílica como substrato. As combinações foram resultantes de cinco doses de nitrogênio (14; 126; 210; 336 e $\left.462 \mathrm{mg} \mathrm{L}^{-1}\right)$ com cinco doses de enxofre ( 3,2; 12,8; 32; 64 e $\left.80 \mathrm{mg} \mathrm{L}^{-1}\right)$, em um esquema fatorial $5^{2}$ incompleto fundamentado em Littell \& Mott (1975). De acordo com esse esquema obtiveram 13 combinações, assim definidas, para nitrogênio e enxofre: 14 e 3,2; 14 e 32; 14 e 80; 126 e 12,8; 126 e 64; 210 e 3,2; 210 e 32; 210 e 80; 336 e 12,8; 336 e 64; 462 e 3,2; 462 e 32; e 462 e 80 mg L L . Foi utilizada a solução nutritiva completa de Sarruge (1975), modificada somente para atender as doses de nitrogênio e de enxofre (Tabela 1). Na escolha das fontes de nitrogênio tomou-se o cuidado de manter a relação de $70 \%$ de $\mathrm{NO}_{3}{ }^{-}$e $30 \%$ de $\mathrm{NH}_{4}{ }^{+}$. Os vasos foram distribuídos segundo o delineamento estatístico de blocos ao acaso, com quatro repetições.

\subsection{Instalação e condução do experimento}

No início do mês de setembro colocaram-se as sementes para a germinar em bandejas plásticas, contendo areia lavada em água corrente e posteriormente em água desionizada. As bandejas receberam periodicamente água desionizada e aos 15 dias após a semeadura, quando as plântulas atingiram cerca de quatro centímetros de altura, realizou-se o transplante de 15 mudas para cada vaso.

Logo após o transplante e durante um período de três dias, cada vaso recebeu um litro de solução diluída a um terço da concentração total correspondente a cada combinação estudada. Após esse estágio, a solução com concentração definitiva foi adicionada, e também procederam-se desbastes periódicos até que permaneceram cinco plantas por vaso. 
As soluções foram circuladas nos vasos seis vezes por dia no estágio inicial de desenvolvimento das plântulas e o volume de solução deixado à noite nos vasos para as plântulas foi sendo reduzido á medida que as plântulas se desenvolviam. Passado esse estágio inicial de desenvolvimento, as soluções começaram a ser circuladas nos vasos três vezes por dia e drenadas à noite e a renovação das soluções se deu a cada 14 dias a partir de sua adição nos vasos.

Tabela 1. Volumes das soluções estoques utilizadas no preparo das soluções nutritivas para as combinações de doses de nitrogênio e de enxofre estudadas.

\begin{tabular}{|c|c|c|c|c|c|c|c|c|c|c|c|c|c|c|}
\hline \multirow{2}{*}{ Nitrogênio } & \multicolumn{14}{|c|}{ Combinações de doses de nitrogênio e enxofre $\left(\mathrm{mg} \mathrm{L}^{-1}\right)$} \\
\hline & & 14 & 14 & 14 & 126 & 126 & 210 & 210 & 210 & 336 & 336 & 462 & 462 & 462 \\
\hline Enxofre & $\mathrm{Mol} \mathrm{L}^{-1}$ & 3,2 & 32 & 80 & 12,8 & 64 & 3,2 & 32 & 80 & 12,8 & 64 & 3,2 & 32 & 80 \\
\hline Soluções & \multicolumn{14}{|c|}{ Volume $\left(\mathrm{ml} \mathrm{L}^{-1}\right)$} \\
\hline estoques & & & & & & & & & & & & & & \\
\hline$\left(\mathrm{NH}_{4}\right)_{2} \mathrm{SO}_{4}$ & 0,1 & 1 & - & - & 0,4 & 1 & 0,1 & 1 & 0,5 & 0,4 & 2 & 0,1 & 1 & 2,5 \\
\hline $\mathrm{NH}_{4} \mathrm{NO}_{3}$ & 0,1 & 1 & - & - & - & - & - & - & - & - & - & - & - & - \\
\hline $\mathrm{NH}_{4} \mathrm{NO}_{3}$ & 1 & - & 0,3 & - & 1,9 & 0,7 & 4,3 & 2,5 & 3,5 & 6,4 & 3,2 & 9,7 & 7,9 & 4,9 \\
\hline $\mathrm{Mg}\left(\mathrm{NO}_{3}\right)_{2}$ & 1 & 0,3 & - & - & 2 & 1 & 2 & 2 & - & 2 & 2 & 2 & 2 & 2 \\
\hline $\mathrm{MgCl}_{2}$ & 1 & 1,7 & 1 & - & & - & - & - & - & - & - & - & - & - \\
\hline $\mathrm{KH}_{2} \mathrm{PO}_{4}$ & 1 & 1 & 1 & 0,7 & 1 & 1 & 1 & 1 & 1 & 1 & 1 & 1 & 1 & 1 \\
\hline $\mathrm{KCl}$ & 1 & 5 & 5 & 4,6 & 5 & 5 & 5 & 5 & 5 & 5 & 5 & 5 & 3,8 & 0,8 \\
\hline $\mathrm{CaCl}_{2}$ & 1 & 5 & 4,8 & 4,5 & 4,8 & 3,2 & 3,9 & 3 & 1,5 & 1,8 & 0,2 & 0,3 & - & - \\
\hline $\mathrm{MgSO}_{4}$ & 1 & - & 1 & 2 & - & 1 & - & - & 2 & - & - & - & - & - \\
\hline $\mathrm{Ca}\left(\mathrm{NO}_{3}\right)_{2}$ & 1 & - & 0,2 & - & 0,2 & 1,8 & 1,1 & 2 & 3,5 & 3,2 & 4,8 & 4,7 & 5 & 5 \\
\hline $\mathrm{KNO}_{3}$ & 1 & - & - & 0,7 & - & - & - & - & - & - & - & - & 1,2 & 4,2 \\
\hline $\mathrm{NH}_{4} \mathrm{H}_{2} \mathrm{PO}_{4}$ & 1 & - & - & 0,3 & - & - & - & - & - & - & - & - & - & - \\
\hline $\mathrm{CaSO}_{4}$ & 0,05 & - & - & 10 & - & - & - & - & - & - & - & - & - & - \\
\hline Micro-Fe ${ }^{*}$ & - & 1 & 1 & 1 & 1 & 1 & 1 & 1 & 1 & 1 & 1 & 1 & 1 & 1 \\
\hline Fe-EDTA** & - & 1 & 1 & 1 & 1 & 1 & 1 & 1 & 1 & 1 & 1 & 1 & 1 & 1 \\
\hline
\end{tabular}

A solução estoque de micronutrientes teve a seguinte composição $\left(\mathrm{g} \mathrm{L}^{-1}\right): \mathrm{H}_{3} \mathrm{BO}_{3}=2,86 ; \mathrm{MnCl}_{2}$. $4 \mathrm{H}_{2} \mathrm{O}=1,81 ; \mathrm{ZnCl}_{2}=0,10 ; \mathrm{CuCl}_{2}=0,04$ e $\mathrm{H}_{2} \mathrm{MoO}_{4}$. $4 \mathrm{H}_{2} \mathrm{O}=0,02$.

** Dissolveram-se 26,1g de EDTA dissódico em $286 \mathrm{~mL}$ de $\mathrm{NaOH} 1 \mathrm{~mol} \mathrm{~L}{ }^{-1}$, misturando-se com 24,0 g de $\mathrm{FeSO}_{4} \cdot 7 \mathrm{H}_{2} \mathrm{O}$, arejando-se por uma noite e completando-se a $1 \mathrm{~L}$ com água desionizada. 
Foram realizados dois cortes das plantas, com o primeiro ocorrendo aos 39 dias após o transplante das mudas e o segundo aos 40 dias após o primeiro corte. Após os cortes a parte aérea das plantas foi separada em: a)folhas emergentes, ou seja as folhas não completamente expandidas; b) lâminas de folhas recém-expandidas, ou seja lâminas das duas folhas mais jovens totalmente expandidas, com lígula visível; c) lâminas de folhas maduras ou seja lâminas das demais folhas totalmente expandidas e d) colmos + bainhas: colmos propriamente ditos e as bainhas que foram mantidas a eles circundadas. Imediatamente após o segundo corte da parte aérea, as raízes foram separadas e lavadas em água corrente e desionizada, utilizando-se um conjunto de peneiras com diâmetro de malha de 0,25 e $1,00 \mathrm{~mm}$.

Todo material colhido foi colocado para secar em estufa de circulação forçada de ar a $70^{\circ} \mathrm{C}$, até peso constante, com posterior pesagem em balança de precisão. Os valores obtidos na pesagem dos componentes da parte aérea foram reunidos para a computação da produção da parte aérea total. Todo material vegetal foi moído em moinho do tipo Wiley e acondicionado em sacos plásticos.

\subsection{Estimativa do teor de clorofila através do valor SPAD}

Para estimativa do teor de clorofila utilizou-se do Chlorophyll Meter SPAD-502, (Soil-plant Analysis Development Section, Minolta Camera Co., Osaka, Japan). Essa medida foi efetuada diretamente (não destrutível) na segunda folha completamente expandida (no sentido do ápice para a base da planta) aos 23 dias após o transplante das mudas e aos 26 dias após o primeiro corte, no terço médio da lâmina, tomando-se o cuidado de evitar a nervura central. Foram realizadas cinco leituras por vaso nas respectivas combinações de nitrogênio e de enxofre, a partir das quais foram obtidas as médias. 


\subsection{Atividade da redutase do nitrato}

A atividade da redutase do nitrato foi avaliada segundo método descrito por Mulder et al. (1959), aos 37 dias após o transplante e aos 24 dias após o primeiro corte. As unidades experimentais foram transferidas para câmara-de-crescimento e deixadas expostas à luz por duas horas, com temperatura constante em torno de $27^{\circ} \mathrm{C}$ para evitar interferências externas na atividade da enzima e promover a homogeneização das parcelas. Após esse período de duas horas coletou-se uma amostra do terço médio da lâmina foliar da última folha recém-expandida. Nas combinações com baixa dose de nitrogênio e baixa dose de enxofre, quando não havia material vegetal suficiente para análise, duas lâminas eram coletadas.

As lâminas foliares foram cortadas em segmentos menores, pesadas (200 mg) e colocadas em tubos de ensaio contendo $4 \mathrm{~mL}$ de $\mathrm{KNO}_{3}(0,25 \mathrm{M})$ em tampão fosfato, ficando incubadas por duas horas. Após este período de incubação, $1 \mathrm{~mL}$ do extrato foi retirado e procedeu-se a determinação do $\mathrm{NO}_{2}{ }^{-}$adicionando-se $1 \mathrm{~mL}$ de ácido sulfanílico e $\mathrm{HCl}$ a $20 \%$ para paralisar a reação de redução do nitrato, e $1 \mathrm{~mL}$ de alfa-naftilamina indicador que ao reagir com o $\mathrm{NO}_{2}{ }^{-}$desenvolve coloração rósea. A leituras foram realizadas no colorímetro no comprimento de onda $560 \mathrm{~nm}$, e posteriormente foi efetuado o cálculo da concentração de $\mathrm{NO}_{2}{ }^{-}$, com o uso de informação da curva padrão.

\subsection{Avaliação da área foliar}

A avaliação da área foliar foi conduzida através do integrador de área foliar na ocasião do primeiro e do segundo crescimentos das plantas. A área foliar foi medida separadamente para as lâminas de folhas emergentes, lâminas das duas folhas-recém expandidas e lâminas de folhas maduras. A área foliar de cada unidade experimental foi obtida pela soma da área foliar de cada componente da parte aérea da planta. 


\subsection{Avaliação da superfície total e comprimento total do sistema radicular}

Para a avaliação da superfície e do comprimento total do sistema radicular uma sub-amostra de raiz (cerca de 20\%) foi coletada após as raízes serem lavadas ao final do

segundo corte. Após a coleta as sub-amostras foram acondicionadas em copos plásticos contendo água desionizada e violeta de metila (corante utilizado para coloração das raízes e radicelas, facilitando assim sua visualização). $\mathrm{Na}$ seqüência, as raízes foram escaneadas e as imagens obtidas foram analisadas pelo aplicativo SIARCS (Sistema Integrado para Análise de Raízes e Cobertura do Solo) versão 3,0. Após serem escaneadas as raízes foram colocadas para secar em estufa de circulação forçada de ar a $70^{\circ} \mathrm{C}$ até peso constante, com posterior pesagem. Com o peso das sub-amostras fez-se a correção do comprimento e superfície específica do sistema radicular de cada vaso, em função da produção de massa seca total das raízes, conforme descrito por Crestana et al. (1994).

\subsection{Produção de massa seca}

A produção de massa seca da parte aérea foi determinada através da soma da massa seca das folhas emergentes, das duas folhas mais jovens totalmente expandidas, das folhas maduras, e dos colmos + bainhas, no primeiro e no segundo crescimentos. A produção da massa seca de raízes foi determinada após o segundo crescimento.

\subsection{Composição mineral}

Após a moagem as amostras de cada componente da parte aérea de ambos os cortes (lâminas de folhas emergentes, lâminas de folhas recém-expandidas, lâminas de folhas maduras e colmos + bainhas) e raízes foram encaminhadas para determinação das concentrações de nitrogênio e de enxofre, conforme metodologia descrita por Sarruge \& Haag (1974). O nitrogênio foi determinado pelo método analítico semi-micro Kjeldahl, após digestão sulfúrica, enquanto a digestão nítrico-perclórica serviu para a preparação 
do extrato a partir do qual foi determinado o enxofre, pelo método da turbidimetria do cloreto de bário. A determinação do fósforo, potássio, cálcio e magnésio foi realizada utilizando-se o tecido das lâminas de folhas recém-expandidas e através da digestão nitrico-perclórica, seguida pelo método analítico de espectrofotometria de absorção atômica, com exceção do potássio que foi determinado pelo método analítico de fotometria de chama.

\subsection{Análises estatísticas}

Todos os resultados receberam o recomendado tratamento estatístico, com análise em superfície de resposta através do emprego do "Statistical Analysis System" (SAS, 1996). Inicialmente foi realizada a análise de variância para as combinações de doses de nitrogênio e enxofre, e em função do nível de significância do teste $\mathrm{F}$ para essas combinações efetuou-se o estudo de regressão polinomial (superfície de resposta) através do comando RSREG. A análise de regressão foi realizada para a emissão de perfilhos e de folhas pelas plantas, a medida indireta do teor de clorofila através da leitura SPAD, a atividade da redutase do nitrato, a área foliar total, a superfície total e o comprimento total do sistema radicular e as produções de massa seca da parte aérea e das raízes, as concentrações de nitrogênio e enxofre, bem como a relação $\mathrm{N}: \mathrm{S}$ nas folhas emergentes, lâminas de folhas recém-expandidas, lâminas de folhas maduras, colmos+bainhas e raízes, e as concentrações de fósforo, potássio, cálcio e magnésio nas lâminas de folhas recém-expandidas. 


\section{RESULTADOS E DISCUSSÃO}

\subsection{Número de perfilhos e de folhas}

\subsubsection{Número total de perfilhos por vaso}

O número total de perfilhos por vaso apresentou comportamento diferenciado do primeiro para o segundo crescimento do capim-Marandu. A interação entre as doses de nitrogênio e as doses de enxofre não foi significativa $(\mathrm{P}>0,05)$ para o número total de perfilhos por vaso na ocasião do primeiro corte. No entanto, foi verificada significância $(\mathrm{P}<0,01)$ apenas para as doses de nitrogênio empregadas na solução nutritiva, ajustandose ao modelo quadrático de regressão (Figura 2). Para o segundo corte observou-se significância $(\mathrm{P}<0,01)$ para a interação entre as doses de nitrogênio e as doses de enxofre (Figura 3).

De acordo com a equação de segundo grau a dose de nitrogênio de $343 \mathrm{mg} \mathrm{L}^{-1}$ foi responsável pelo máximo perfilhamento do capim-Marandu por ocasião do primeiro crescimento. Esta dose de nitrogênio para a ocorrência do máximo perfilhamento é pouco mais elevada da dose encontrada por Lavres Júnior (2001) que também observou que o nitrogênio aumentou o perfilhamento do capim-Mombaça e a dose de nitrogênio de $296 \mathrm{mg} \mathrm{L}^{-1}$ promoveu sua maximização. Também Braga (2001), em estudo com o capim-Mombaça com nitrogênio, observou ser a dose de nitrogênio de $406 \mathrm{~kg} \mathrm{ha}^{-1}$ a responsável pelo maior perfilhamento.

No presente trabalho a produção máxima de perfilhos por vaso foi $65,6 \%$ maior que a mínima produção de perfilhos por vaso, reafirmando que o nitrogênio atua de forma positiva no perfilhamento das plantas. 
Colozza (1998), em estudo com o capim-Aruana adubado com doses de nitrogênio, observou que o maior número de perfilhos ocorreu com as doses de nitrogênio de 150 e $233 \mathrm{mg} \mathrm{dm}^{-3}$ para o primeiro e segundo crescimentos, respectivamente.

Santos Junior (2001) observou que o número de perfilhos do capim-Marandu dentro de cada idade de crescimento foi alterado significativamente pelas doses de nitrogênio na solução nutritiva, observando também que as doses de nitrogênio necessárias para o máximo número de perfilhos foram 260, 305, 300, 302 e $336 \mathrm{mg} \mathrm{L}^{-1}$ nas idades de 28, 35, 42, 49 e 56 dias, respectivamente.

Rodrigues (2002), estudando a aplicação de calcário, nitrogênio e enxofre para a recuperação do capim-Braquiária cultivado em solo proveniente de uma pastagem degradada, observou que o maior número de perfilhos ocorria nas mais elevadas doses de nitrogênio (630 e $1080 \mathrm{mg} \mathrm{kg}^{-1}$ ).

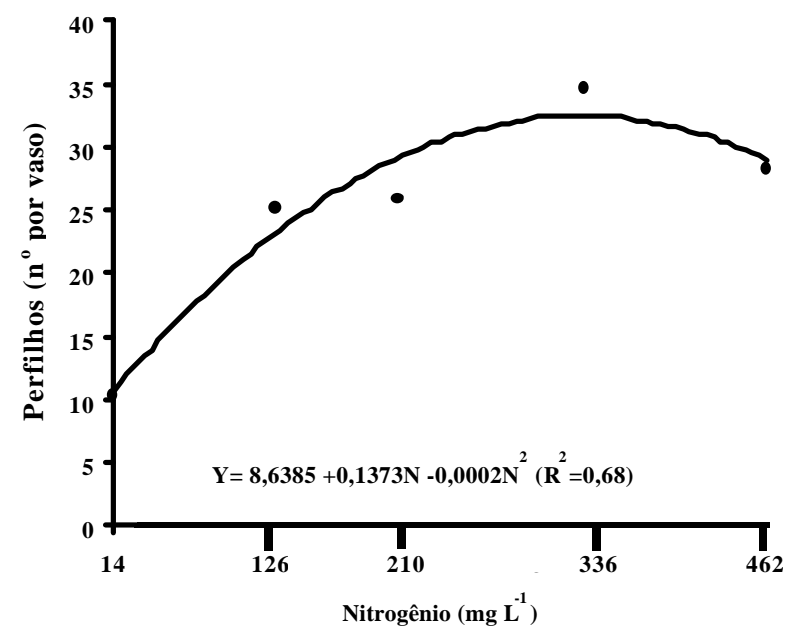

Figura 2 - Número total de perfilhos por vaso, na ocasião do primeiro corte do capimMarandu, em função das doses de nitrogênio na solução nutritiva.

No segundo crescimento, a interação foi significativa $(\mathrm{P}<0,01)$ para as doses de nitrogênio e de enxofre e houve ajuste dos resultados ao modelo polinomial (Figura 3). A maior produção de perfilhos por vaso na ocasião do segundo crescimento foi 
observada na dose de nitrogênio de $416 \mathrm{mg} \mathrm{L}^{-1}$ associada à dose de enxofre de $56,6 \mathrm{mg} \mathrm{L}^{-1}$ (numa relação entre essas doses de 7,3:1).

Pode-se observar na Figura 3 que a planta responde sempre positivamente às doses de nitrogênio associadas às doses de enxofre, sendo que para as doses de nitrogênio um platô é formado entre as doses de 350 e $462 \mathrm{mg} \mathrm{L}^{-1}$. No entanto para as doses de enxofre observa-se que o platô é formado entre as doses de 41,6 e 70,4 mg L $\mathrm{L}^{-1}$ e que a partir daí ocorre redução no perfilhamento, ou seja o aumento de produção a partir deste ponto poderia ser todo creditado à ação do nitrogênio.

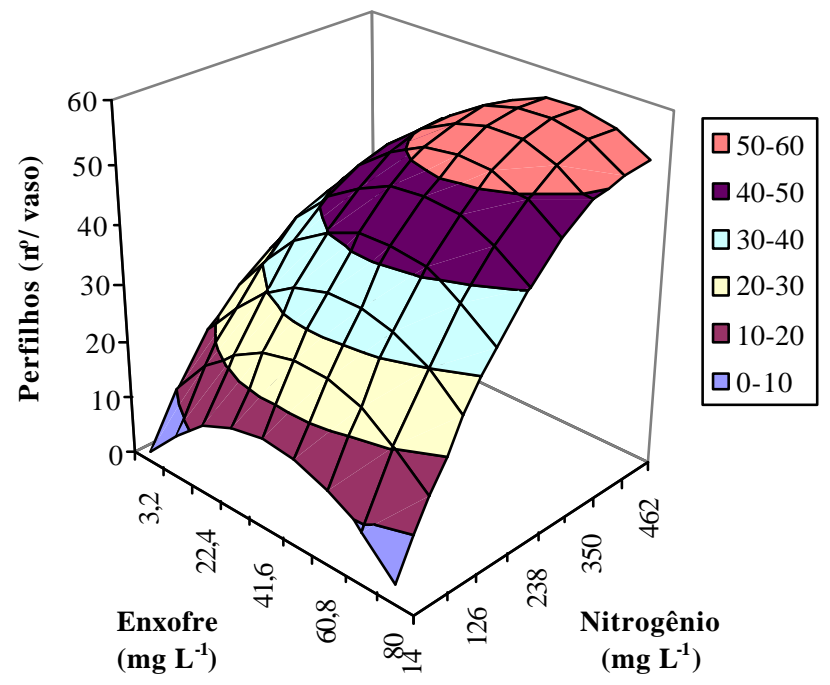

$$
Y=-3,2815+0,1808 N-0,0002 N^{2}+0,7654 S-0,0090 S^{2}+0,0006 N S\left(R^{2}=0,86\right)
$$

Figura 3 - Número total de perfilhos por vaso, na ocasião do segundo corte do capimMarandu , em função das combinações de doses de nitrogênio com doses de enxofre na solução nutritiva.

Como já era de se esperar o número de perfilhos no segundo crescimento foi mais elevado que o do primeiro crescimento, e isto pode ser explicado pelo fato que no período inicial de crescimento a planta concentra a maior parte de sua energia para o seu estabelecimento, ocupando-se com a formação do seu sistema radicular e da sua parte aérea. No segundo período de crescimento, a planta já está estabelecida ou seja, já possui 
um maior volume radicular tendo dessa forma capacidade para absorver maior quantidade de nutrientes, e também pelo fato de ter sofrido a ação do corte que acaba promovendo a indução das gemas basais, originando novos perfilhos.

Santos \& Monteiro (1999), trabalhando com o capim-Braquiária submetido a doses de enxofre, observaram que o perfilhamento da forrageira foi alterado significativamente pelas doses de enxofre, apenas no segundo crescimento, e que as doses de enxofre de 64 e $80 \mathrm{mg} \mathrm{L}^{-1}$ não diferiram entre si.

Considerando-se os relatos de Santos \& Monteiro (1999) com os resultados deste experimento pode-se abordar que a atuação do enxofre foi melhorada pela presença do nitrogênio, já que as combinações entre os dois nutrientes resultaram em benefício para o aproveitamento do enxofre, de acordo com o observado com a aplicação da dose de nitrogênio de $416 \mathrm{mg} \mathrm{L}^{-1}$ associada à dose de enxofre de $56,6 \mathrm{mg} \mathrm{L}^{-1}$.

Rodrigues (2002) verificou interação significativa entre as doses de enxofre, nitrogênio e calcário no capim-Braquiária na ocasião do segundo crescimento, observando que as doses de enxofre $\left(0,108\right.$ e $\left.216 \mathrm{mg} \mathrm{kg}^{-1}\right)$ associadas às doses de nitrogênio de 630 e $1080 \mathrm{mg} \mathrm{kg}^{-1}$ promoveram o maior número de perfilhos por vaso.

\subsubsection{Número total de folhas verdes expandidas por vaso}

Na análise de variância para o número total de folhas verdes expandidas por vaso do capim-Marandu, verificou-se significância $(\mathrm{P}<0,05)$ para a interação entre as doses de nitrogênio e de enxofre fornecidas na solução nutritiva, em ambos os cortes, ajustando-se ao modelo polinomial de regressão.

Analisando-se a superfície de resposta do número total de folhas verdes expandidas por vaso do capim-Marandu, por ocasião do primeiro crescimento, observou-se que a menor produção de folhas ocorreu nas combinações de baixas doses de nitrogênio (14 a $70 \mathrm{mg} \mathrm{L}^{-1}$ ) para todas as doses de enxofre e à medida que se incrementou a dose de nitrogênio ocorreu aumento na produção de folhas (Figura 4). 
O estudo da superfície de resposta da produção de folhas verdes expandidas por vaso, na ocasião do primeiro crescimento, demonstrou que a dose de nitrogênio de 358,8 mg L $\mathrm{L}^{-1}$ associada à dose de enxofre de $65,9 \mathrm{mg} \mathrm{L}^{-1}$ promoveu a maximização do número de folhas (relação entre as doses foi de 5,4:1).

Ruggieri et al. (1994) observaram que o aumento das concentrações de nitrogênio resultou em tendência de aumento na porcentagem de folhas, reafirmando a necessidade da planta por nitrogênio para a formação das folhas.

A interação significativa $(\mathrm{P}<0,01)$ entre as doses de nitrogênio e de enxofre também foi observada para a produção total de folhas verdes expandidas por vaso no segundo crescimento, e o modelo de regressão polinomial foi o que ajustou-se aos resultados (Figura 5).

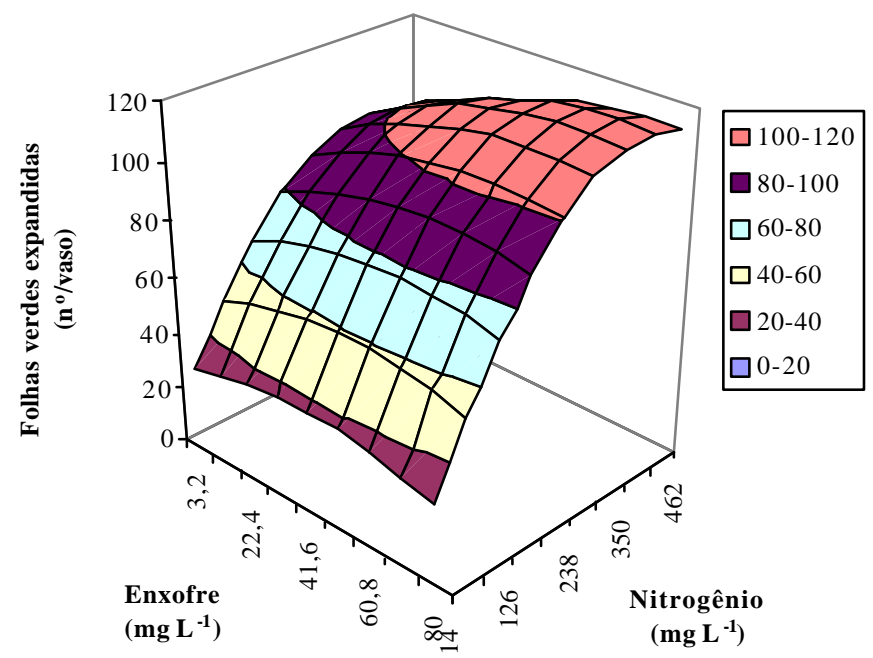

\section{$Y=22,8159+0,4071 N-0,0006 N^{2}+0,4022 S-0,0051 S^{2}+0,0008 N S\left(R^{2}=0,81\right)$}

Figura 4 - Produção total de folhas verdes por vaso, na ocasião do primeiro corte do capim-Marandu, em função das combinações de doses de nitrogênio com doses de enxofre na solução nutritiva.

A superfície de resposta indicou que a maior produção de folhas verdes expandidas por vaso, na ocasião do segundo crescimento, ocorreu na combinação de doses de nitrogênio de $379 \mathrm{mg} \mathrm{L}^{-1}$ e de enxofre de $59 \mathrm{mg} \mathrm{L}^{-1}$ ( relação entre doses de 
6,4:1) e a formação de um platô entre as combinações de doses de nitrogênio de 350 a $406 \mathrm{mg} \mathrm{L}^{-1}$ associadas as doses de enxofre de 22,4 a $32 \mathrm{mg} \mathrm{L}^{-1}$. A superfície mostrou também que à medida que se aumentou as doses de nitrogênio associadas às doses de enxofre ocorreu incremento na produção de folhas.

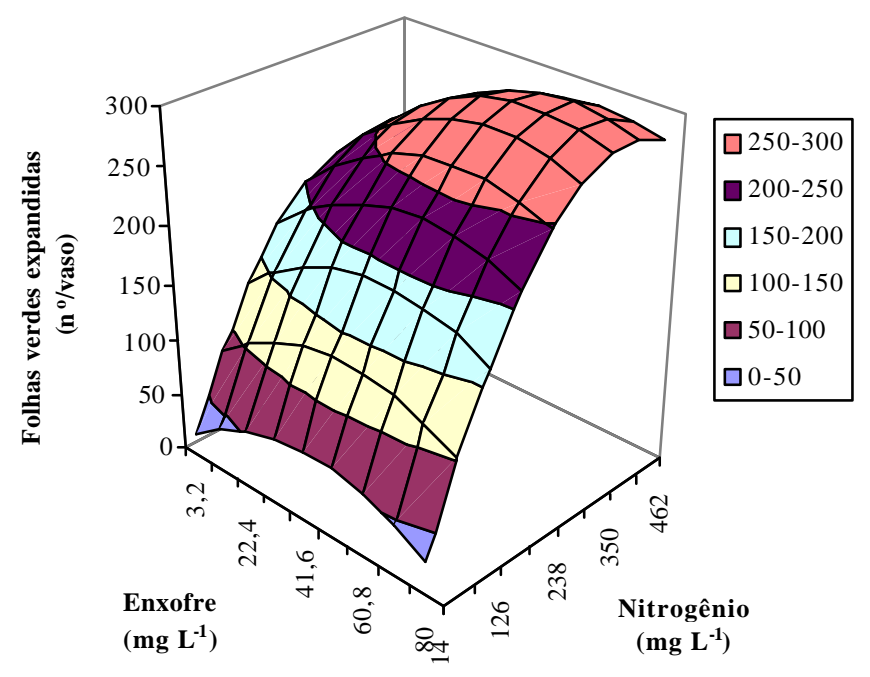

$Y=-4,4768+1,2739 N-0,0019 N^{2}+2,3142 S-0,0267 S^{2}+0,0022 N S\left(R^{2}=0,91\right)$

Figura 5 - Produção total de folhas verdes por vaso, na ocasião do segundo corte do capim-Marandu, em função das combinações de doses de nitrogênio com doses de enxofre na solução nutritiva.

A necessidade deste equilíbrio entre o fornecimento de nitrogênio e enxofre torna-se fator de grande importância para a produção de fotossintetizados pela planta, já que segundo Chapman \& Lamaire (1993) o número de folhas por perfilho e o tamanho da folha são componentes importantes para o índice de área foliar, sendo este último o principal fator que influencia a interceptação da luz. 


\subsection{Estimativa do teor de clorofila em unidades de SPAD}

A análise de variância dos valores da estimativa do teor de clorofila nas lâminas de folhas recém-expandidas através do valor SPAD revelou significância $(\mathrm{P}<0,01)$ para a interação entre as doses de nitrogênio e de enxofre fornecidas na solução nutritiva para o primeiro crescimento, e significância $(\mathrm{P}<0,05)$ para a interação entre essas doses no segundo crescimento.

Os valores da estimativa do teor de clorofila nas lâminas das folhas recémexpandidas do capim-Marandu por ocasião do primeiro crescimento responderam ao suprimento de nitrogênio e enxofre ajustando-se ao modelo polinomial (Figura 6). A análise de variância do valor SPAD demonstrou a ocorrência de um ponto de sela e portanto o máximo valor SPAD não pode ser determinado.

O estudo da superfície de resposta mostrou, na ocasião do primeiro corte, que à medida que se aumentou as doses de nitrogênio na solução nutritiva para qualquer das doses de enxofre, ocorreu elevação do valor SPAD, enquanto que para uma mesma dose de nitrogênio associada a incrementos na dose de enxofre o valor SPAD permanecia constante, comprovando desta maneira que o nitrogênio foi fundamental para alteração dos valores SPAD.

Os valores SPAD por ocasião do primeiro crescimento foram maiores em combinações de altas doses de nitrogênio (350 a $462 \mathrm{mg} \mathrm{L}^{-1}$ ) para qualquer das doses de de enxofre. No entanto, em condições de mais alta dose de enxofre a quantidade de nitrogênio disponível não estaria sendo adequada para que a relação de equilíbrio fosse mantida.

Abreu \& Monteiro (1999) observaram o máximo valor SPAD no capimMarandu nas doses de nitrogênio de 205 e 314,5 mg kg-1. Ao analisarem as equações obtidas relataram que, aos 14, 28 e 42 dias de crescimento da forrageira, o valor SPAD variou entre 31, 8 e 14 para a não aplicação de nitrogênio e entre 51, 57 e 46, tendo esses máximos valores correspondido às doses calculadas de 228, 239 e $302 \mathrm{mg} \mathrm{kg} \mathrm{kg}^{-1}$, respectivamente. 
Os valores da estimativa do teor de clorofila nas lâminas das folhas recémexpandidas do capim-Marandu no segundo crescimento ajustaram-se ao modelo polinomial de regressão (Figura 7), e de acordo com este modelo a combinação de doses de nitrogênio de 533,4 $\mathrm{mg} \mathrm{L}^{-1}$ (dose além da máxima estudada) e de enxofre de 55,5 mg $\mathrm{L}^{-1}$ na solução nutritiva, promoveria os mais altos valores de SPAD.

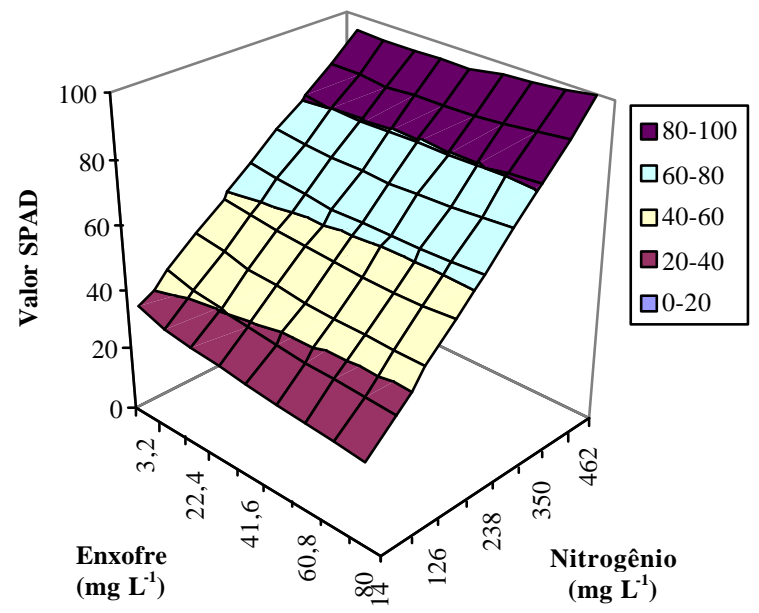

$Y=35,4373+0,1307 N-0,0002 N^{2}-0,2341 S-0,0012 S^{2}+0,0004 N S\left(R^{2}=0,85\right)$

Figura 6 - Estimativa do teor de clorofila em unidades de SPAD na ocasião do primeiro crescimento, em função das combinações de doses de nitrogênio com doses de enxofre na solução nutritiva.

$\mathrm{Na}$ ocasião do segundo crescimento observou-se que aumentando-se a dose de enxofre, até um certo limite $\left(3,2\right.$ a 41,6 $\left.\mathrm{mg} \mathrm{L}^{-1}\right)$, associada ao incremento da dose de nitrogênio ocorria elevação nos valores de SPAD. Estudando-se a superfície de resposta observa-se que um platô começou a ser formado entre as doses de nitrogênio de 406 a $462 \mathrm{mg} \mathrm{L}^{-1}$ associadas as doses de enxofre de 32 a $70,4 \mathrm{mg} \mathrm{L}^{-1}$.

Esses resultados reafirmam a necessidade do equilíbrio na relação entre o nitrogênio e o enxofre, já verificada por Mattos (2001), que também constatou interação entre as doses de nitrogênio e de enxofre para este parâmetro. $\mathrm{O}$ autor observou ainda que no primeiro crescimento o valor SPAD foi menor na não aplicação de enxofre com 
$200 \mathrm{mg} \mathrm{dm}^{-3}$ de ritrogênio, tendo o mais alto valor SPAD ocorrido na dose de enxofre de $47 \mathrm{mg} \mathrm{dm}^{-3}$ com nitrogênio em $200 \mathrm{mg} \mathrm{dm}^{-3}$, e no segundo crescimento efeitos significativos das doses de nitrogênio em cada uma das doses de enxofre.

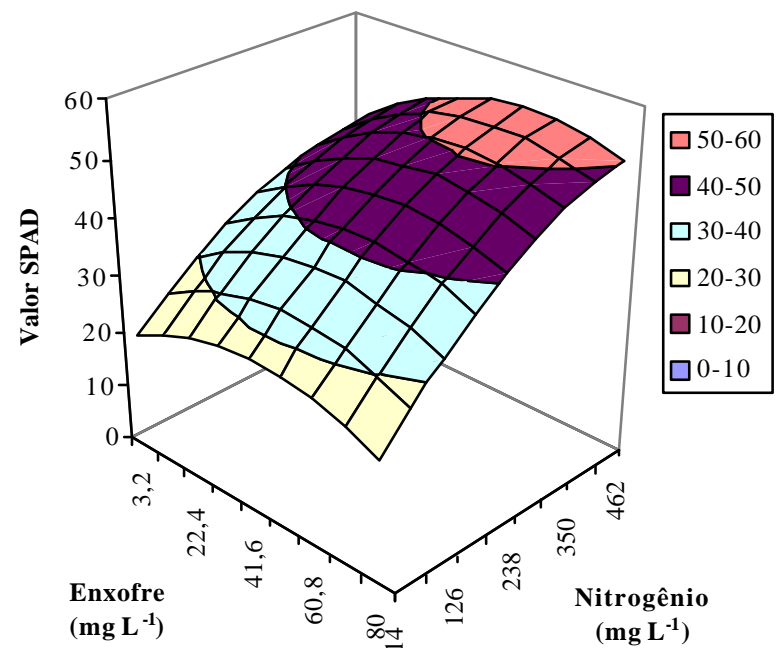

$Y=18,1351+0,0959 N-0,0001 N^{2}+0,3669 S-0,0043 S^{2}+0,0002 N S\left(R^{2}=0,89\right)$

Figura 7 - Estimativa do teor de clorofila em unidades de SPAD na ocasião do segundo crescimento, em função das combinações de doses de nitrogênio com doses de enxofre na solução nutritiva.

\subsection{Atividade da redutase do nitrato}

Para a atividade da enzima redutase do nitrato não foi observada interação significativa $(\mathrm{P}>0,05)$ entre as doses de nitrogênio e de enxofre tanto no primeiro como no segundo crescimento da forrageira. Essa resposta significativa também não foi observada para as doses individuais de nitrogênio e de enxofre, em ambos os crescimentos.

Estes resultados diferem do que foi relatado por Santos (1997) em estudo relativo à diagnose nutricional e às respostas do capim-Braquiária a doses de nitrogênio e de enxofre, onde o nitrogênio estimulou a atividade da redutase do nitrato no primeiro 
crescimento e as doses de enxofre influenciaram a atividade da redutase do nitrato nos dois crescimentos. Lavres Júnior (2001) também observou que a atividade da redutase do nitrato no capim-Mombaça apresentou significância para as doses de nitrogênio e na ocasião do segundo crescimento, valores mais altos poderiam ser alcançados com doses mais elevadas que $462 \mathrm{mg} \mathrm{L}^{-1}$ de nitrogênio na solução nutritiva.

\section{4 Área foliar total}

A área foliar total do capim-Marandu apresentou interação significativa entre as doses de nitrogênio e de enxofre na solução nutritiva, tanto no primeiro corte $(\mathrm{P}<0,01)$ como no segundo corte $(\mathrm{P}<0,05)$.

No primeiro corte a área foliar total ajustou-se ao modelo polinomial de regressão e através do estudo da superfície de resposta constatou-se que a dose de nitrogênio de 479,7 $\mathrm{ng} \mathrm{\textrm {L } ^ { - 1 }}$ associada à dose de enxofre de $147 \mathrm{mg} \mathrm{L}^{-1}$ (excedendo a máxima dose estudada) apresentaria a maior área foliar total por ocasião do primeiro crescimento (Figura 8).

$\mathrm{Na}$ análise de variância dos valores de área foliar total por ocasião do segundo corte o modelo de regressão polinomial ajustou-se melhor aos resultados (Figura 9). De acordo com o estudo da superfície de resposta a dose de nitrogênio de $381,6 \mathrm{mg} \mathrm{L}^{-1}$ combinada com a dose de enxofre de $54,8 \mathrm{mg} \mathrm{L}^{-1}$ (relação entre doses de 70:1) apresentou a naior área foliar total por ocasião do segundo crescimento. O maior valor de área foliar total observado por ocasião do segundo crescimento foi $97 \%$ superior em relação ao mínimo valor .

O valor absoluto de área foliar total produzida no segundo crescimento da planta forrageira foi superior ao primeiro. Comparando-se os dois períodos de crescimento das plantas a máxima área foliar no segundo corte foi 50,9\% maior daquela obtida no primeiro corte.

Pode-se observar na Figura 9 a formação de um platô entre as doses de

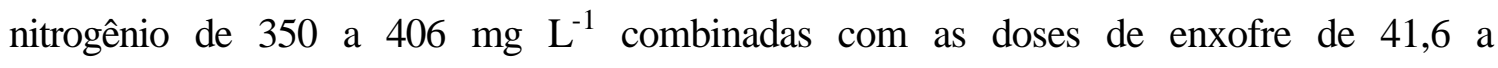
$60,8 \mathrm{mg} \mathrm{L}^{-1}$, sendo também responsável pelos maiores valores de área foliar. 


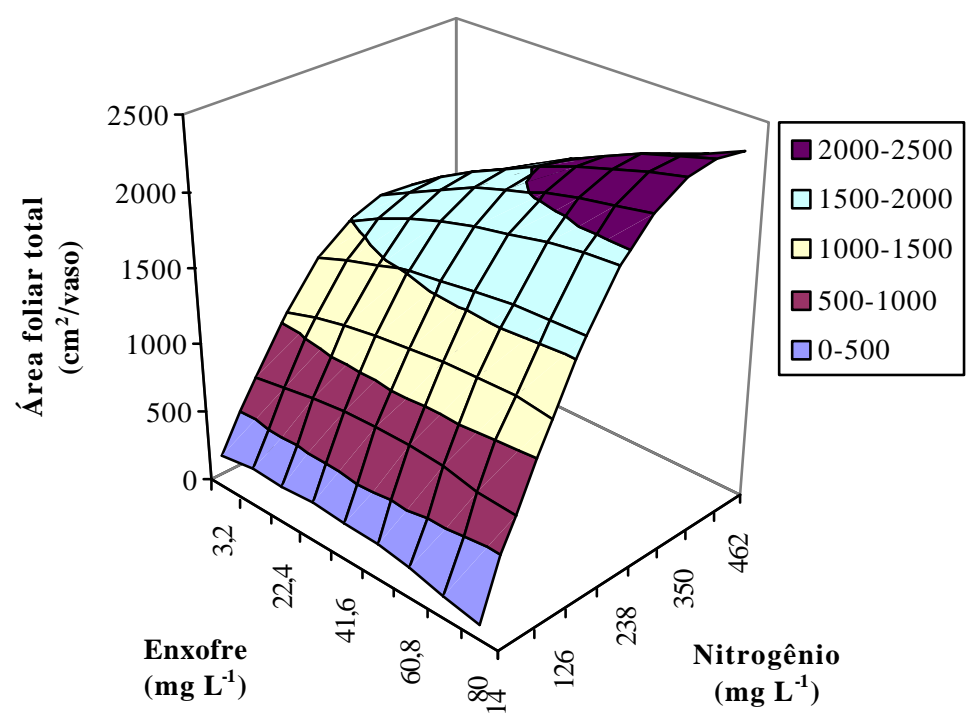

$Y=105,6811+9,1469 \mathrm{~N}-0,0147 \mathrm{~N}^{2}+3,3624 \mathrm{~S}-0,0661 \mathrm{~S}^{2}+0,0335 \mathrm{NS}\left(\mathrm{R}^{2}=0,92\right)$

Figura 8 - Área foliar total no primeiro corte do capim-Marandu, em função das combinações de doses de nitrogênio com doses de enxofre na solução nutritiva.

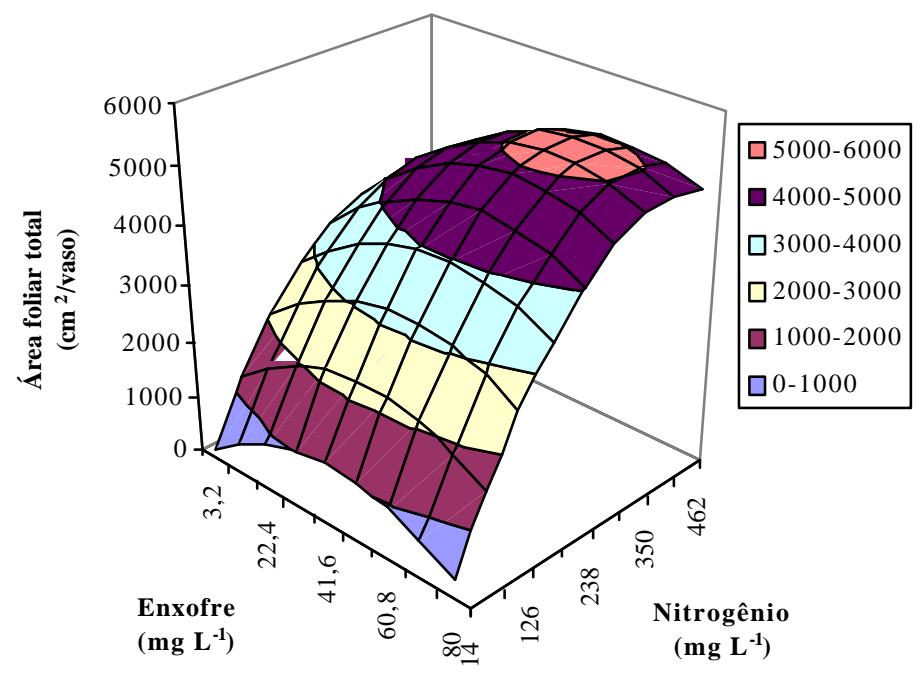

$Y=-309,1404+21,4086 \mathrm{~N}-0,0306 \mathrm{~N}^{2}+50,9832 S-0,5891 \mathrm{~S}^{2}-0,0355 \mathrm{NS}\left(\mathrm{R}^{2}=0,91\right)$

Figura 9 - Área foliar total no segundo corte do capim-Marandu, em função das combinações de doses de nitrogênio com doses de enxofre na solução nutritiva. 
Esses resultados reafirmam a necessidade do fornecimento de nitrogênio e enxofre como recomendada por Mattos (2001), que observou, no primeiro crescimento do capim-Braquiária, efeito significativo para as doses de nitrogênio $(50,100$ e $200 \mathrm{mg} \mathrm{dm}^{-3}$ ) dentro de cada uma das doses de enxofre (30 e $60 \mathrm{mg} \mathrm{dm}^{-3}$ ). Os pontos de máxima área foliar total ocorreram naquele capim nas doses de nitrogênio de 122, 125 e $220 \mathrm{mg} \mathrm{dm}^{-3}$ e nas doses de enxofre de 0,30 e $60 \mathrm{mg} \mathrm{dm}^{-3}$, respectivamente. Também foi relatada significância para a aplicação de enxofre dentro das doses de nitrogênio de 100 e $200 \mathrm{mg} \mathrm{dm}^{-3}$, enquanto no terceiro crescimento, observou efeito significativo do nitrogênio dentro das doses de enxofre.

\subsection{Comprimento total e superfície total do sistema radicular}

$\mathrm{Na}$ análise de variância para superfície total e comprimento total do sistema radicular do capim-Marandu não se observou significância $(\mathrm{P}>0,05)$ para a interação entre as doses de nitrogênio e de enxofre fornecidas na solução nutritiva. Entretanto foi observada significância $(\mathrm{P}<0,01)$ para as doses de nitrogênio fornecidas na solução nutritiva (Figura 10).

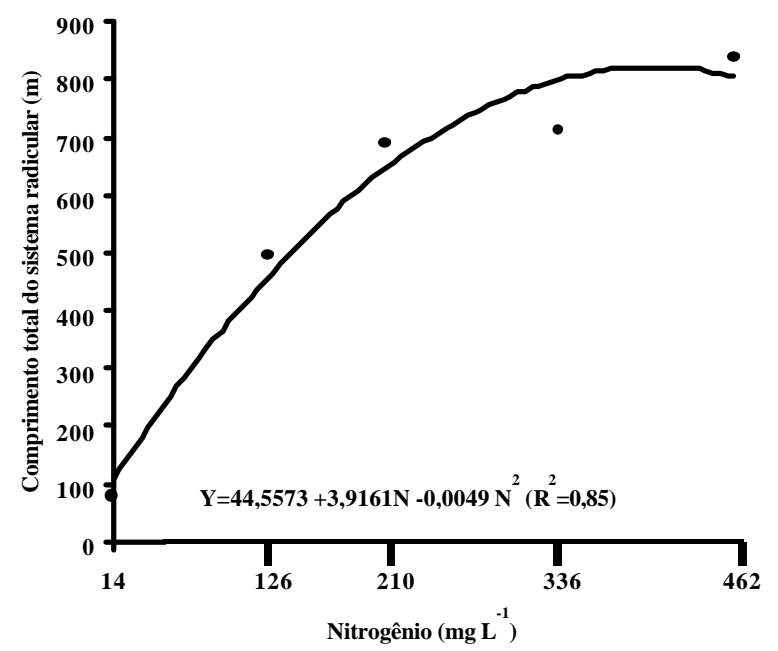

Figura 10 - Comprimento total do sistema radicular do capim-Marandu em função das doses de nitrogênio na solução nutritiva. 
Constatou-se através da equação de regressão de segundo grau que a dose de nitrogênio de 399,6 $\mathrm{mg} \mathrm{L}^{-1}$ foi responsável pelo maior comprimento total de raízes. Nessa dose o comprimento total de raízes foi $88 \%$ mais elevado que o presente na mais baixa dose de nitrogênio $\left(14 \mathrm{mg} \mathrm{L}^{-1}\right)$.

Santos Júnior (2001) observou que os máximos comprimentos radiculares do capim-Marandu corresponderam às doses de nitrogênio de 207; 199; 199; 236 e $294 \mathrm{mg} \mathrm{L}^{-1}$, nas idades de crescimento de 21, 28, 35, 42 e 49 dias, respectivamente. No presente experimento as plantas foram cortadas com 39 dias após o transplante das mudas para os vasos e 40 dias de rebrota após o primeiro corte.

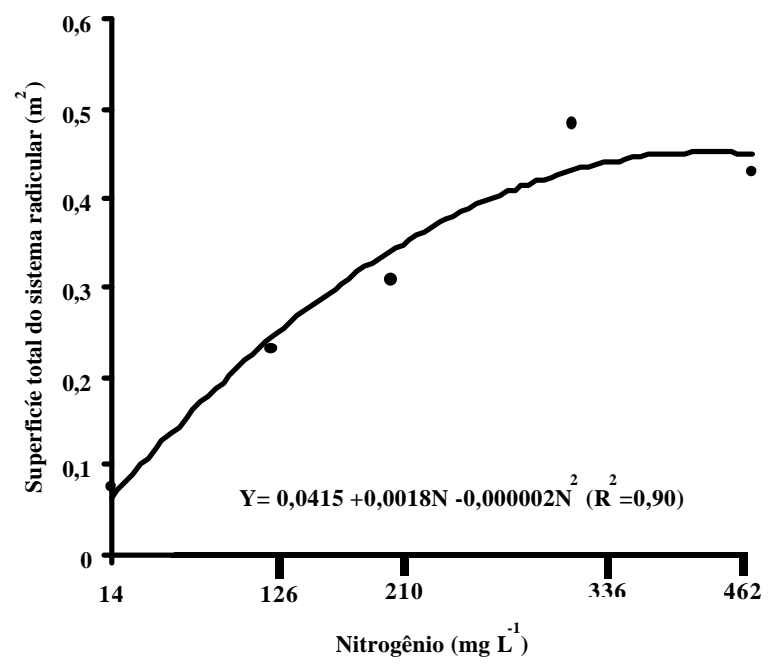

Figura 11 - Superfície total do sistema radicular do capim-Marandu em função das doses de nitrogênio na solução nutritiva.

Para a superfície total do sistema radicular a análise de variância indicou que o modelo quadrático foi o que melhor ajustou-se aos resultados (Figura 11), sendo a dose de nitrogênio de $450 \mathrm{mg} \mathrm{L}^{-1}$ a que apresentou a maior superfície total do sistema radicular.

Santos Júnior (2001) verificou que os máximos valores de superficíe radicular do capim-Marandu corresponderam às doses de nitrogênio de 200; 195; 217; 259 e $312 \mathrm{mg} \mathrm{L}^{-1}$ na solução nutritiva, nas idades de crescimento de 21, 28, 35, 42 e 49 dias, respectivamente. 


\subsection{Produção de massa seca da planta}

\subsubsection{Produção de massa seca da parte aérea}

A produção de massa seca da parte aérea apresentou comportamento diferenciado entre o primeiro e o segundo cortes. No primeiro corte a análise de variância apresentou significância $(\mathrm{P}<0,01)$ para a interação entre as doses de nitrogênio e de enxofre fornecidas na solução nutritiva. No segundo crescimento a produção de massa seca da parte aérea mostrou significância $(\mathrm{P}<0,05)$ somente para as doses de nitrogênio empregadas, com ajuste ao modelo quadrático de regressão.

No primeiro crescimento a produção de massa seca da parte aérea respondeu ao suprimento conjunto de nitrogênio e de enxofre, ajustando-se ao modelo polinomial (Figura 12). De acordo com a superfície de resposta o valor de maior produção de massa seca ocorreria na dose de nitrogênio de 510,8 $\mathrm{mg} \mathrm{L}^{-1}$ (excedendo a máxima utilizada) associada à dose de enxofre de $210 \mathrm{mg} \mathrm{L}^{-1}$ ( também mais elevada que os $80 \mathrm{mg} \mathrm{L}^{-1}$ empregados). A produção de massa seca da parte aérea com baixo suprimento de nitrogênio e de enxofre foi $91,3 \%$ mais baixa em relação a dose que promoveria a máxima produção de massa seca.

O estudo da superfície de resposta da massa seca da parte aérea, no primeiro corte, mostrou que em condições de baixas doses de nitrogênio mesmo com o incremento das doses de enxofre a produção de massa seca da parte aérea permanecia constante, mas no entanto à medida que se aumentou as doses de nitrogênio associadas as doses de enxofre a produção de massa seca foi incrementada.

Abreu \& Monteiro (1999) observaram que as produções de massa seca da parte aérea do capim-Marandu, avaliadas aos 14, 28 e 42 dias do crescimento inicial variaram significativamente com as doses de nitrogênio e as máximas produções foram obtidas nas doses de 140, 152 e $190 \mathrm{mg} \mathrm{kg}^{-1}$.

Hoffman (1992) verificou que a produção de massa seca produzida pela parte aérea do capim-Braquiária no primeiro corte foi maior que na rebrota. Relatou mais baixas produções de massa seca no segundo corte, principalmente nas doses mais 
elevadas de enxofre, sendo justificada, pelo menos em parte, por uma decapitação mais intensa por ocasião do primeiro corte.

Marques et al. (1995) observaram que a omissão de enxofre não interferiu no rendimento total de massa seca da parte aérea da Brachiaria brizantha quando cultivada na microregião Campos da Mantiqueira - MG. Entretanto Monteiro et al. (1995) observaram reduções significativas na produção de massa seca e na altura de plantas no tratamento em que se omitiu enxofre, quando comparado com o tratamento completo.

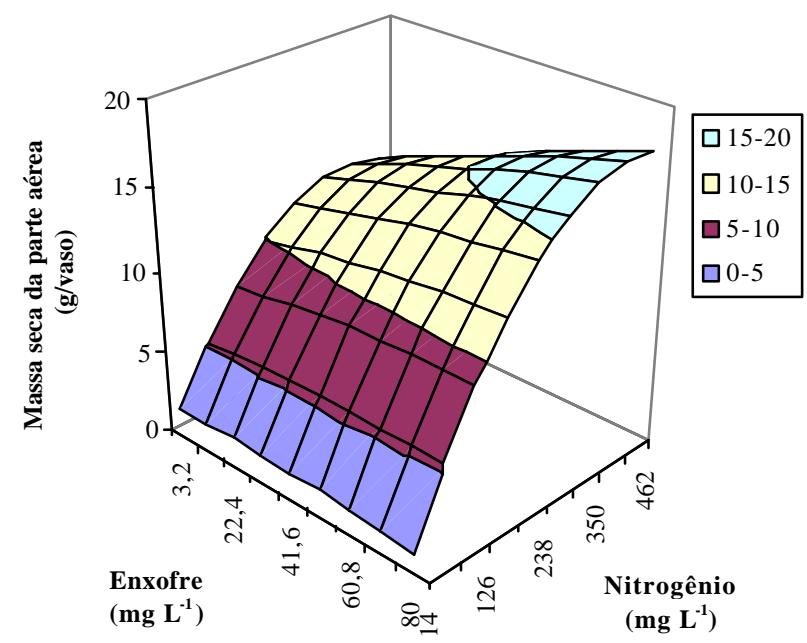

$Y=0,8579+0,0673 N-0,0001 N^{2}+0,0058 S-0,0002 S^{2}+0,0002 N S\left(R^{2}=0,89\right)$

Figura 12 - Produção de massa seca da parte aérea do capim-Marandu, na ocasião do primeiro corte, em função das combinações de doses de nitrogênio e de enxofre na solução nutritiva.

No segundo corte verificou-se através da regressão quadrática que a dose de nitrogênio para a máxima produção de massa seca foi de $369,8 \mathrm{mg} \mathrm{L}^{-1}$ (Figura 13). Nesse crescimento, a produção de massa seca foi maior em relação ao primeiro crescimento, efeito que pode ser atribuído a necessidade maior de energia no primeiro crescimento para o desenvolvimento e formação do sistema radicular e da estrutura da parte aérea. No segundo crescimento, como a planta já estava com seu sistema radicular 
formado a energia foi destinada apenas para o desenvolvimento da parte aérea contribuindo para o aumento da produção de massa seca.

Monteiro \& Werner (1977) observaram que o requerimento de nitrogênio é maior após o desenvolvimento inicial da gramínea, incrementando a produção de massa seca, bem como a concentração e a produção de proteína bruta. Nesse sentido, também Werner et al. (1967) verificaram que, à exceção da adubação fosfatada, a falta de adubação nitrogenada foi a que mais influenciou no crescimento inicial do capimColonião, limitando a produção de massa seca e número de perfilhos.

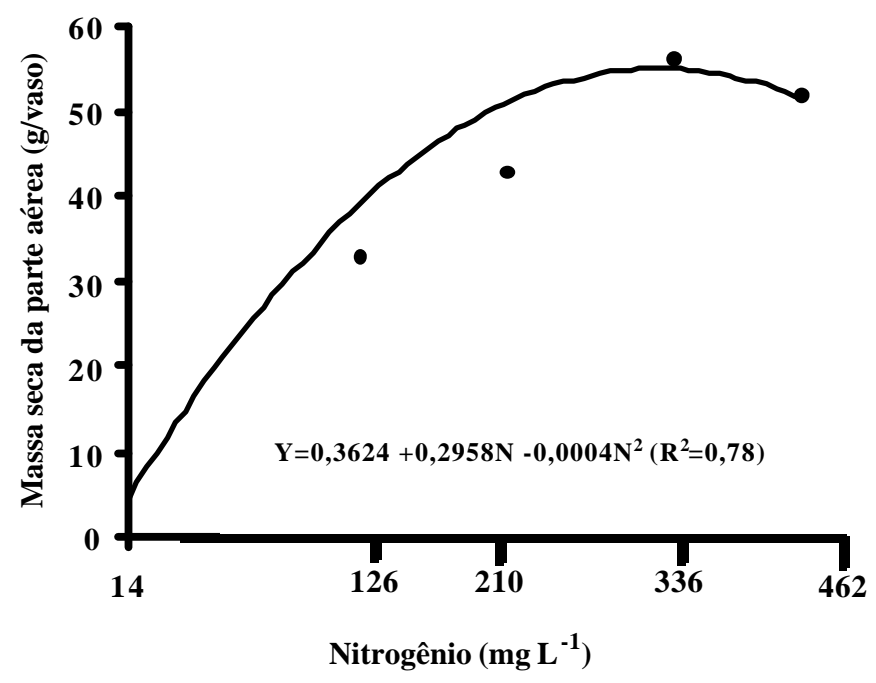

Figura 13 - Produção de massa seca da parte aérea do capim-Marandu, na ocasião do segundo corte, em função das doses de nitrogênio na solução nutritiva.

Em estudo realizado por Santos \& Monteiro (1999) as doses de enxofre de 78 e $62 \mathrm{mg} \mathrm{L}^{-1}$ foram as que proporcionaram as máximas produções de massa seca da parte aérea no primeiro e segundo crescimentos do capim-Braquiária. 


\subsubsection{Produção de massa seca das raízes}

Para a produção de massa seca de raízes não foi observada significância $(P>0,05)$ para a interação entre as doses de nitrogênio e de enxofre. Entretanto a significância $(\mathrm{P}>0,01)$ foi observada para as doses de nitrogênio (Figura 14).

A produção de massa seca das raízes apresentou ajuste ao modelo quadrático, sendo que a dose de nitrogênio que apresentaria o máximo valor de produção de massa seria mais elevada que a máxima empregada neste experimento (462 $\mathrm{mg} \mathrm{L}^{-1}$ ). Constatouse também que nas mais baixas doses de nitrogênio a produção representou $6 \%$ da máxima produção de raízes. Santos \& Monteiro (1999) verificaram aumento na produção de massa seca de raízes da ordem de 39\%, entre a não aplicação de enxofre e a dose de $80 \mathrm{mg} \mathrm{L}^{-1}$.

Santos Júnior (2001) observou que as doses de nitrogênio necessárias para a máxima produção de massa seca de raízes capim-Marandu foram 235,0; 256,2; 327,2; 358,6 e $303,1 \mathrm{mg} \mathrm{L}^{-1}$ aos 28, 35, 42, 49 e 56 dias de crescimento, respectivamente.

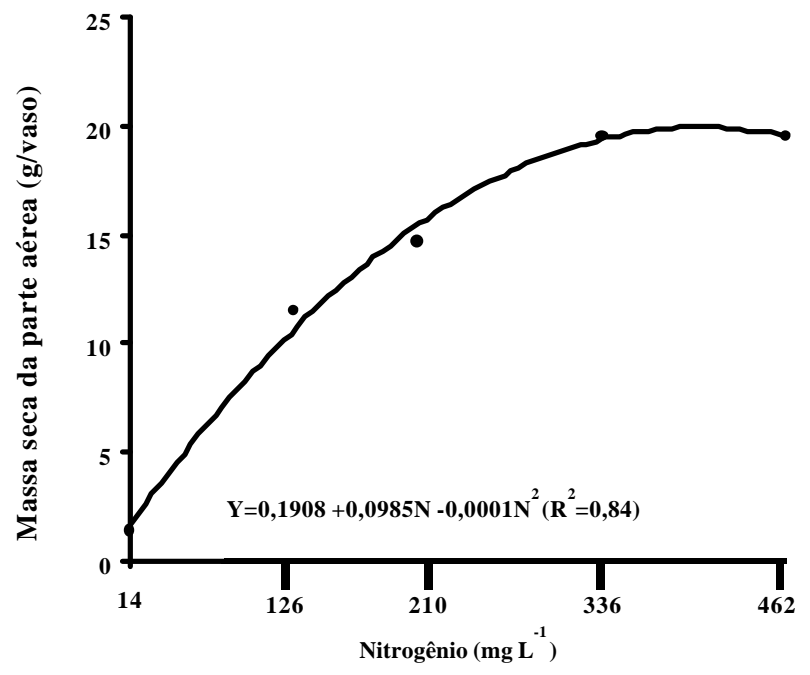

Figura 14 - Produção de massa seca de raízes do capim-Marandu em função das doses de nitrogênio na solução nutritiva. 


\subsection{Concentração de nutrientes na planta}

\subsubsection{Concentração de nitrogênio nas folhas emergentes}

Para a concentração de nitrogênio nas folhas emergentes, não se observou interação significativa $(\mathrm{P}>0,05)$ entre as doses de nitrogênio e de enxofre fornecidas na solução nutritiva no primeiro crescimento do capim, observando-se significância $(\mathrm{P}<0,01)$ apenas para as doses individuais de nitrogênio (Figura 15). Entretanto para a concentração de nitrogênio nas folhas emergentes por ocasião do segundo corte observou-se significância $(\mathrm{P}<0,05)$ para a interação entre as doses de nitrogênio e de enxofre na solução nutritiva.

A concentração de nitrogênio nas folhas emergentes no primeiro corte, em função do fornecimento de nitrogênio na solução nutritiva, apresentou ajuste à equação de primeiro grau (Figura 15). O maior valor de concentração de nitrogênio nas folhas emergentes foi de 31,6 $\mathrm{g} \mathrm{kg}^{-1}$ e ocorreu na dose de nitrogênio de $462 \mathrm{mg} \mathrm{L}^{-1}$, fornecida na solução nutritiva, demonstrando que, para o capim-Marandu, a dose de nitrogênio de $210 \mathrm{mg} \mathrm{L}^{-1}$ sugerida por Sarruge (1975) não é suficiente para suprir as necessidades da planta.

A concentração de nitrogênio nas folhas emergentes na dose de nitrogênio de $462 \mathrm{mg} \mathrm{L}^{-1}$ por ocasião do primeiro corte foi $38 \%$ mais elevada que na mais baixa dose de nitrogênio $\left(14 \mathrm{mg} \mathrm{L}^{-1}\right)$ fornecida na solução nutritiva.

Santos (1997), estudando a diagnose nutricional e as respostas do capimBraquiária submetido a doses de nitrogênio e enxofre, observou que no primeiro corte deste capim ocorreu pequena variação na concentração de nitrogênio nas folhas emergentes, observando que a dose de nitrogênio de $406 \mathrm{mg} \mathrm{L}^{-1}$ foi a que proporcionou a máxima concentração de nitrogênio $\left(23,8 \mathrm{~g} \mathrm{~kg}^{-1}\right.$ de nitrogênio).

Estudando as respostas do capim-Mombaça a doses de nitrogênio em solução nutritiva Manarin (2000) verificou que as folhas emergentes no primeiro corte respondiam linearmente às doses de nitrogênio aplicadas (de 0 a $462 \mathrm{mg} \mathrm{L}^{-1}$ ), e a variação na concentração de nitrogênio era de 7,3 a $23,7 \mathrm{~g} \mathrm{~kg}^{-1}$. 
O estudo da análise de variância da concentração de nitrogênio nas folhas emergentes, no segundo corte, revelou a existência de um ponto de sela e deste modo não foi possível a determinação da concentração máxima de nitrogênio nas folhas emergentes (Figura 16).

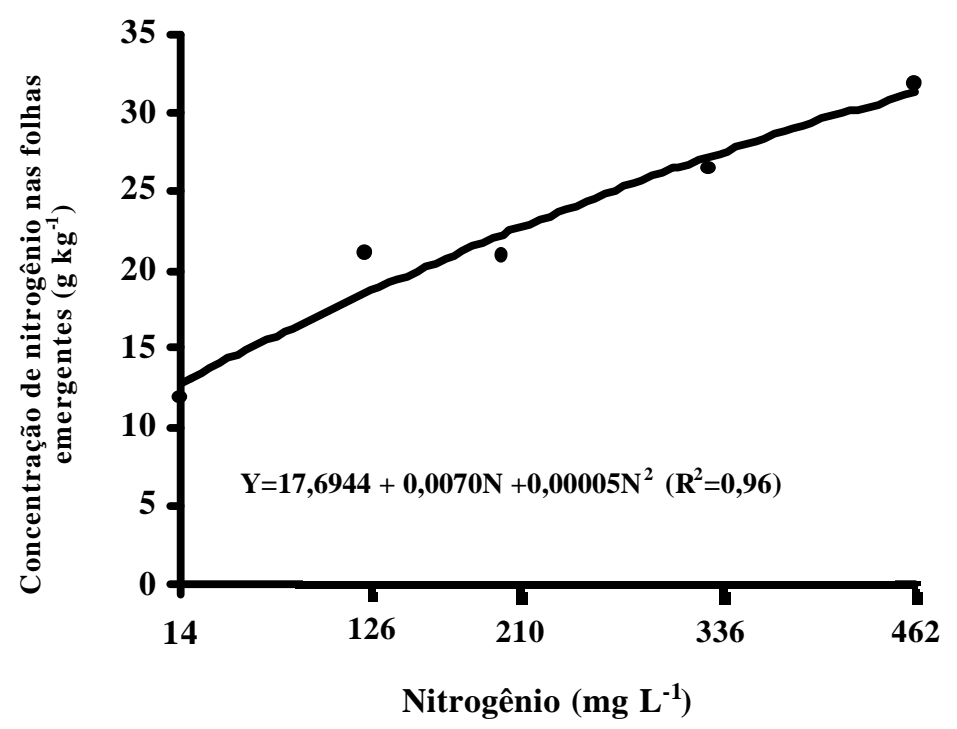

Figura 15 - Concentração de nitrogênio nas de folhas emergentes do capim-Marandu na ocasião do primeiro corte, em função das doses de nitrogênio na solução nutritiva.

A concentração de nitrogênio nas folhas emergentes no segundo corte variou de 11,5 a 21,6 $\mathrm{g} \mathrm{kg}^{-1}$, resultado da combinação das mais baixas doses de nitrogênio e de enxofre para as mais altas doses deles, respectivamente.

A superfície de resposta, demonstrou que à medida em que se aumentaram as doses de nitrogênio e enxofre, na solução nutritiva, ocorreu elevação da concentração de nitrogênio neste tecido.

Santos (1997) observou que na ocasião do segundo corte do capim-Braquiária a máxima concentração de nitrogênio de $17,1 \mathrm{~g} \mathrm{~kg}^{-1}$ era obtida na dose de nitrogênio de $342 \mathrm{mg} \mathrm{L}^{-1}$ na solução nutritiva. 
Manarin (2000) verificou que as folhas emergentes do capim-Mombaça, no segundo corte, respondiam linearmente às doses de nitrogênio, ocorrendo variação na concentração de nitrogênio de 11,4 a $24,5 \mathrm{~g} \mathrm{~kg}^{-1}$. Ressaltou ainda que essa parte da planta tanto no primeiro como no segundo corte foi a que apresentou mais elevada concentração de nitrogênio quando o capim foi submetido à mais elevadas doses de nitrogênio na solução nutritiva, justificando ser isto o reflexo da movimentação do nitrogênio para as partes novas da planta.

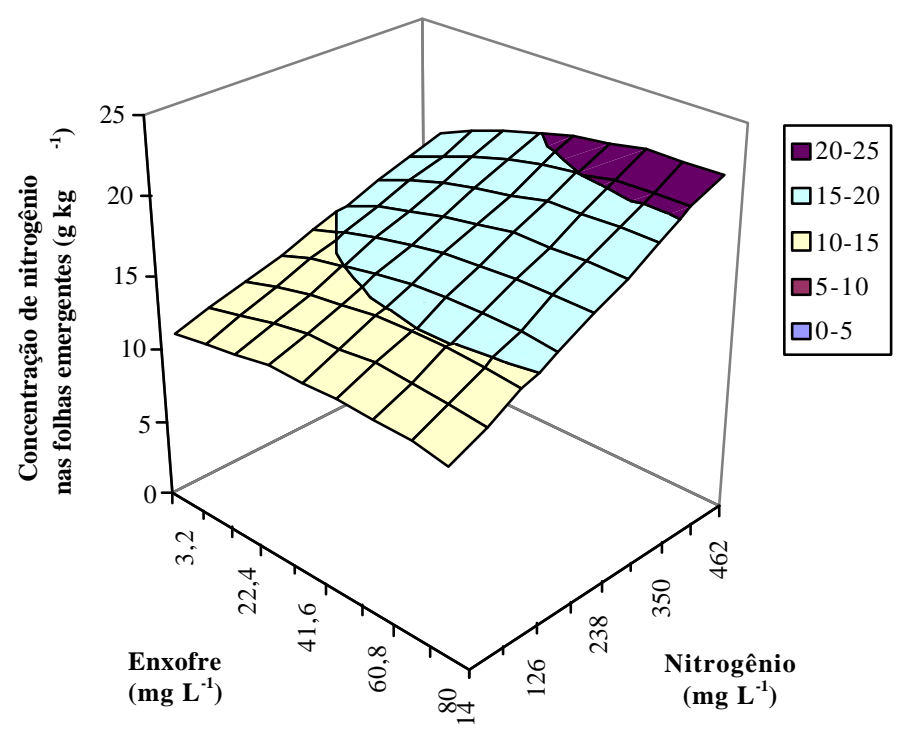

$Y=11,0920+0,0129 N+0,0000003 N^{2}+0,0623 S-0,0007 S^{2}+0,0001 N S\left(R^{2}=0,80\right)$

Figura 16 - Concentração de nitrogênio nas folhas emergentes do capim-Marandu na ocasião do segundo corte, em função das combinações de doses de nitrogênio com doses de enxofre na solução nutritiva.

\subsubsection{Concentração de nitrogênio nas lâminas de folhas recém-expandidas}

A análise de variância para a concentração de nitrogênio nas lâminas de folhas recém-expandidas do capim-Marandu não apresentou significância $(\mathrm{P}>0,05)$ para a 
interação entre as doses de nitrogênio e enxofre, em ambos os cortes. Entretanto resposta significativa $(\mathrm{P}<0,01)$ foi observada para as doses individuais de nitrogênio na solução nutritiva, nos dois cortes realizados.

A concentração de nitrogênio nas lâminas de folhas recém-expandidas na ocasião do primeiro corte ajustou-se ao modelo quadrático(Figura 17). O mais elevado valor de concentração de nitrogênio das lâminas de folhas recém-expandidas foi de $31 \mathrm{~g} \mathrm{~kg}^{-1} \mathrm{e}$ ocorreu na dose de nitrogênio de $462 \mathrm{mg} \mathrm{L}^{-1}$. O intervalo de concentração entre a menor e a maior dose de nitrogênio de acordo com a equação de segundo grau variou de 16 a $31 \mathrm{~g} \mathrm{~kg}^{-1}$.

Santos (1997) encontrou resposta linear para a concentração de nitrogênio nas lâminas de folhas recém-expandidas no primeiro corte do capim-Braquiária. A concentração de nitrogênio nestas lâminas variou de 12,6 a 27,5 $\mathrm{g} \mathrm{kg}^{-1}$ nos limites das doses de nitrogênio estudadas (0 a $\left.462 \mathrm{mg} \mathrm{L}^{-1}\right)$.

As respostas fisiológicas, bioquímicas e produtivas do capim-Mombaça a doses de nitrogênio foram estudadas por Manarin (2000) que observou variação na concentração de nitrogênio nas lâminas de folhas recém-expandidas de 8,8 a $18,5 \mathrm{~g} \mathrm{~kg}^{-1}$ entre às mais baixa e a mais alta dose de nitrogênio, respectivamente.

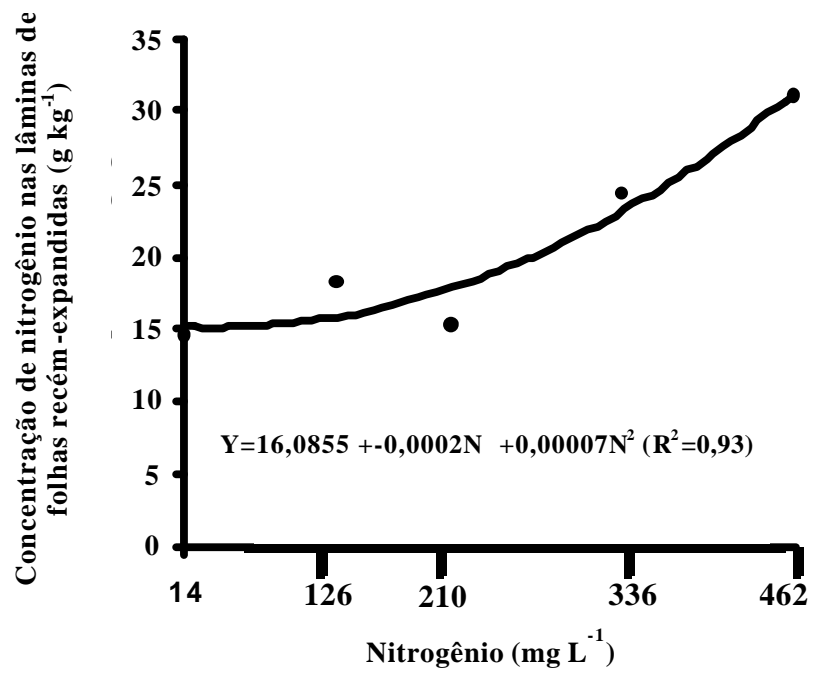

Figura 17 - Concentração de nitrogênio nas lâminas de folhas recém-expandidas do capim-Marandu, na ocasião do primeiro corte, em função das doses de nitrogênio na solução nutritiva. 
Mattos (2001), avaliando uma pastagem de capim- Braquiária em degradação e sua recuperação com suprimento de nitrogênio e enxofre constatou no experimento com forrageira proveniente de área não recentemente adubada, que a concentração de nitrogênio nas lâminas de folhas recém-expandidas na ocasião do primeiro corte variou entre 12,2 e 30,0 $\mathrm{g} \mathrm{kg}^{-1}$, da mais baixa e a mais alta dose de nitrogênio aplicada ( 0 e 200 $\left.\mathrm{mg} \mathrm{dm}^{-3}\right)$. No experimento com forrageira proveniente de área recentemente adubada a concentração de nitrogênio nesse corte variou entre 11,5 e $18,0 \mathrm{~g} \mathrm{~kg}^{-1}$, respectivamente, para a não aplicação e para a dose mais elevada de nitrogênio no experimento.

No segundo corte, a concentração de nitrogênio nas lâminas de folhas recémexpandidas ajustou-se a modelo linear de regressão, de tal modo que a dose de nitrogênio de $462 \mathrm{mg} \mathrm{L}^{-1}$ fornecida na solução nutritiva promoveu a mais elevada concentração de nitrogênio nas lâminas foliares (Figura 18). O intervalo de concentração de acordo com a equação de primeiro grau entre a menor e a maior dose de nitrogênio variou de 9,5 a 16,9 $\mathrm{g} \mathrm{kg}^{-1}$. Resultados semelhantes a este foram obtidos por Manarin (2000) ao estudar as respostas do capim-Mombaça a doses de nitrogênio na solução nutritiva, ocasião em que a concentração de nitrogênio nas lâminas de folhas recémexpandidas variou de 10 a $19 \mathrm{~g} \mathrm{~kg}^{-1}$ entre a mais baixa e a mais alta dose de nitrogênio (0 a $\left.462 \mathrm{mg} \mathrm{L}^{-1}\right)$, respectivamente.

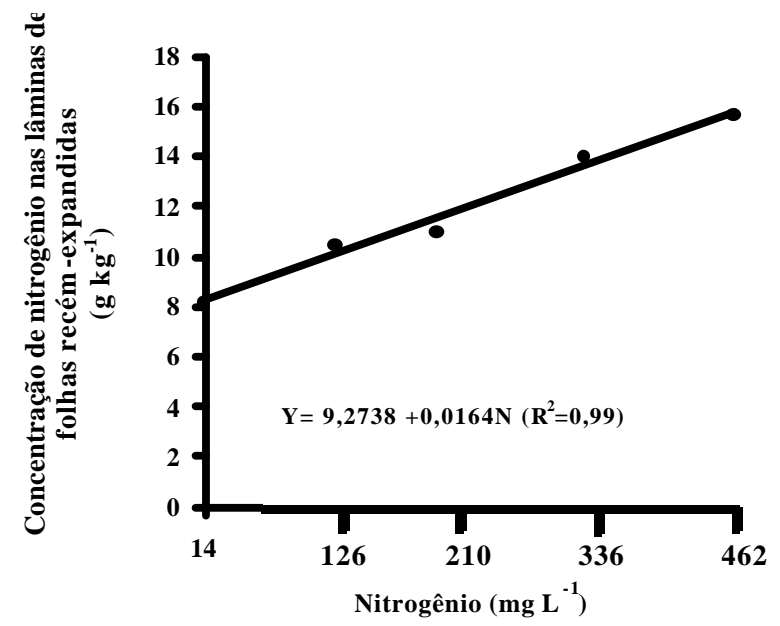

Figura 18 - Concentração de nitrogênio nas lâminas de folhas recém-expandidas do capim-Marandu, na ocasião do segundo corte, em função das doses de nitrogênio na solução nutritiva. 
Avaliando separadamente as respostas do capim-Braquiária a doses de nitrogênio e de enxofre em solução nutritiva, Santos (1997) verificou na ocasião do segundo corte que a concentração de nitrogênio nas lâminas de folhas recém-expandidas ajustou-se ao modelo quadrático de regressão. A máxima concentração de nitrogênio na dose de nitrogênio de $391 \mathrm{mg} \mathrm{L}^{-1}$ na solução nutritiva, resultou na concentração de nitrogênio de $19 \mathrm{~g} \mathrm{~kg}^{-1}$ naquele experimento.

Abreu (1999) observou que a concentração de nitrogênio nas lâminas de folhas recém-expandidas do capim-Marandu de acordo com as idades de 14, 28 e 42 dias e as doses de nitrogênio aplicadas no solo, ajustaram-se ao modelo quadrático de regressão e de acordo com este modelo, aos 14 dias a dose de nitrogênio de $290 \mathrm{mg} \mathrm{L} \mathrm{L}^{-1}$ proporcionou a mais alta concentração de nitrogênio nas lâminas de folhas recémexpandidas (40 $\mathrm{g} \mathrm{kg}^{-1}$ ), e aos 28 e 42 dias as doses para a máxima concentração de nitrogênio (47 e $20 \mathrm{~g} \mathrm{~kg}^{-1}$ respectivamente) estariam em 566 e $524 \mathrm{mg} \mathrm{L}^{-1}$ (além dos limites estudados), respectivamente.

Colozza et al. (2000), estudando as respostas do capim-Aruana a doses de nitrogênio na ocasião do segundo corte, observou que à medida que se aumentava a dose de nitrogênio ocorria incremento da concentração de nitrogênio nas lâminas de folhasrecém expandidas.

Manarin (2000) relatou que no segundo corte do capim-Mombaça a concentração de nitrogênio nas lâminas de folhas recém-expandidas esteve entre 10 e $19 \mathrm{~g} \mathrm{~kg}^{-1}$, quando variava da mais baixa para a mais elevada dose de nitrogênio, respectivamente.

Mattos (2001), em experimento com o capim-Braquiária com suprimento de nitrogênio e enxofre em área não recentemente adubada, observou que a concentração de nitrogênio variou significativamente $(\mathrm{P}<0,05)$ nas lâminas de folhas recém-expandidas no segundo corte, em função das doses de nitrogênio dentro de cada dose de enxofre.

Santos Júnior (2001) relatou que a concentração de nitrogênio nas lâminas de folhas recém-expandidas do capim-Marandu, dentro de cada idade de crescimento, variou significativamente com as doses de nitrogênio. Essa variação foi linear nas idades de crescimento de 35, 42, 49 e 56 dias e seguiu modelo quadrático de regressão nas 
idades de 21 e 28 dias, sendo as máximas concentrações de nitrogênio correspondentes às doses de nitrogênio de 260 e $270 \mathrm{mg} \mathrm{L}^{-1}$ nas idades de crescimento de 21 e 28 dias, respectivamente.

\subsubsection{Concentração de nitrogênio nas lâminas de folhas maduras}

A análise de variância da concentração de nitrogênio nas lâminas de folhas maduras não demonstrou significância $(\mathrm{P}>0,05)$ para a interação entre as combinações de doses de nitrogênio e doses de enxofre fornecidas na solução nutritiva, em ambos os cortes do capim. Entretanto, observou-se resposta significativa $(\mathrm{P}<0,05)$ para as doses de nitrogênio fornecidas na solução nutritiva por ocasião do primeiro corte (Figura 19), ajustando-se a equação de segundo grau. Na ocasião do segundo corte não se observou resposta significativa $(\mathrm{P}>0,05)$ para as doses de nitrogênio ou de enxofre fornecidas na solução nutritiva.

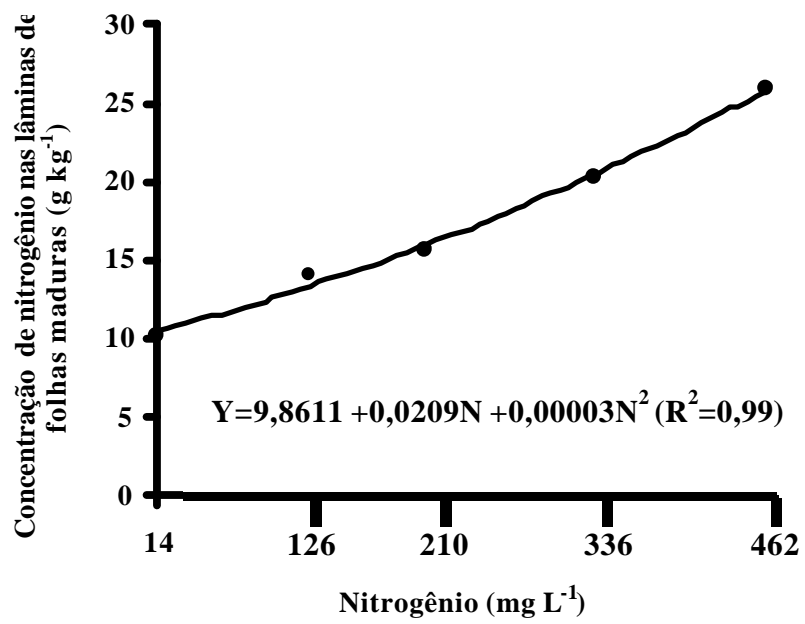

Figura 19 - Concentração de nitrogênio nas lâminas de folhas maduras do capimMarandu, na ocasião do primeiro corte, em função das doses de nitrogênio na solução nutritiva.

No primeiro corte a mais alta concentração de nitrogênio nas lâminas de folhas maduras foi de 26,1 $\mathrm{g} \mathrm{kg}^{-1}$ e ocorreu na dose de nitrogênio de $462 \mathrm{mg} \mathrm{L}^{-1}$. Este valor 
encontra-se acima dos observados por Manarim (2000) trabalhando com o capimMombaça, onde os valores encontrados situavam-se na faixa de 7 a $13 \mathrm{~g} \mathrm{~kg}^{-1}$ em condições de ausência de aplicação de nitrogênio a mais alta dose de nitrogênio (462 $\mathrm{mg} \mathrm{L}^{-1}$ ), respectivamente.

No primeiro corte do capim-Braquiária, Santos (1997) observou que a máxima concentração de nitrogênio $\left(21,4 \mathrm{~g} \mathrm{~kg}^{-1}\right)$ nas lâminas de folhas maduras era obtida na dose de nitrogênio de $433 \mathrm{mg} \mathrm{L}^{-1}$.

\subsubsection{Concentração de nitrogênio nos colmos + bainhas}

A análise de variância da concentração de nitrogênio nos colmos + bainhas revelou interação não significativa $(\mathrm{P}>0,05)$ entre as doses de nitrogênio e de enxofre na solução nutritiva, tanto no primeiro como no segundo corte. Entretanto, verificou-se resposta significativa $(\mathrm{P}<0,01)$ para as doses de nitrogênio na ocasião do primeiro corte. Por ocasião do segundo corte não se observou significância $(\mathrm{P}>0,05)$ para doses individuais de nitrogênio e de enxofre fornecidas na solução nutritiva.

Os resultados da concentração de nitrogênio nos colmos + bainhas no primeiro crescimento apresentou ajuste à equação de segundo grau (Figura 20). De acordo com esta equação a concentração de nitrogênio variou de 13,9 a $31,4 \mathrm{~g} \mathrm{~kg}^{-1}$ da mais baixa para a mais elevada dose de nitrogênio respectivamente.

Em estudo realizado com o capim-Braquiária submetido a doses de nitrogênio de enxofre, Santos (1997) observou, na ocasião do primeiro corte, que embora a concentração de nitrogênio nos colmos+bainhas ajustasse ao modelo linear de regressão, esta foi a parte da planta que apresentou as mais baixas concentrações de nitrogênio.

Manarin (2000) não observou efeito significativo $(\mathrm{P}>0,05)$ das oito doses de nitrogênio na solução nutritiva ( 0 a $\left.462 \mathrm{mg} \mathrm{L}^{-1}\right)$, em termos da concentração de nitrogênio nos colmos+bainhas do capim-Mombaça.

Lavres Júnior (2001), estudando o capim-Mombaça, verificou na ocasião do

primeiro corte que a concentração de nitrogênio nos colmos + bainhas ajustava-se a 
modelo linear de regressão, constatando que a concentração de nitrogênio nesta parte da planta variou entre 5,3 a $19,9 \mathrm{~g} \mathrm{~kg}^{-1}$ com as doses mínima (28 $\left.\mathrm{mg} \mathrm{L}^{-1}\right)$ e máxima (462 $\mathrm{mg} \mathrm{L}^{-1}$ ) de nitrogênio.

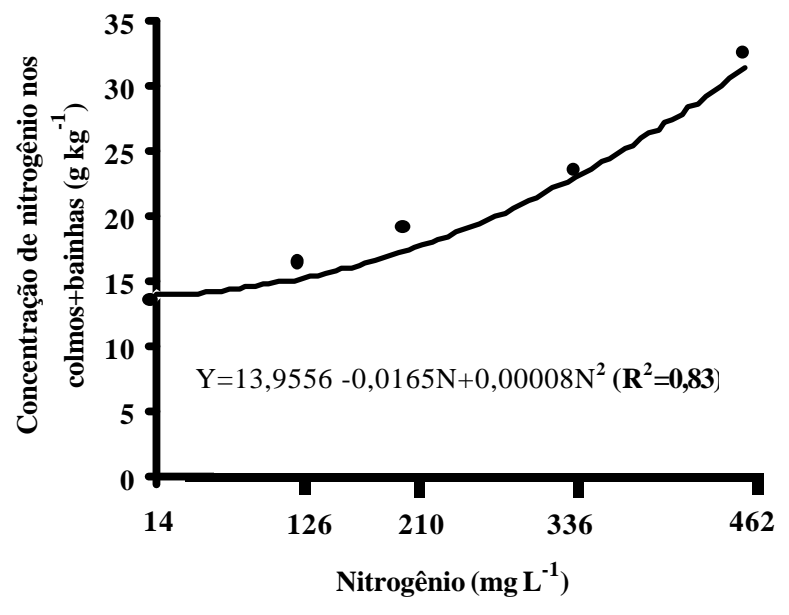

Figura 20 - Concentração de nitrogênio nos colmos + bainhas do capim-Marandu, na ocasião do primeiro corte, em função das doses de nitrogênio na solução nutritiva.

\subsubsection{Concentração de nitrogênio nas raízes}

Para a concentração de nitrogênio no tecido radicular observou-se interação significativa $(\mathrm{P}<0,01)$ entre as doses de nitrogênio e de enxofre. $\mathrm{O}$ modelo de regressão polinomial permitiu ajuste dos valores de concentrações em relação às doses desses dois nutrientes no substrato (Figura 21). 
A análise de variância da concentração de nitrogênio nas raízes indicou a existência de um ponto de sela e deste modo a concentração máxima de nitrogênio nas raízes não pode ser determinada. Entretanto o modelo de regressão polinomial demonstrou que a concentração de nitrogênio no tecido radicular variou de $2,4 \mathrm{~g} \mathrm{~kg}^{-1} \mathrm{a}$ $29,5 \mathrm{~g} \mathrm{~kg}^{-1}$.

O estudo da superfície de resposta da concentração de nitrogênio nas raízes demonstrou que para todas as doses de enxofre a medida que se aumentava as doses de nitrogênio ocorria elevação na concentração de nitrogênio nas raízes, entretanto observou-se que as mais altas concentrações de nitrogênio encontravam-se em altas doses de nitrogênio e baixas doses de enxofre.

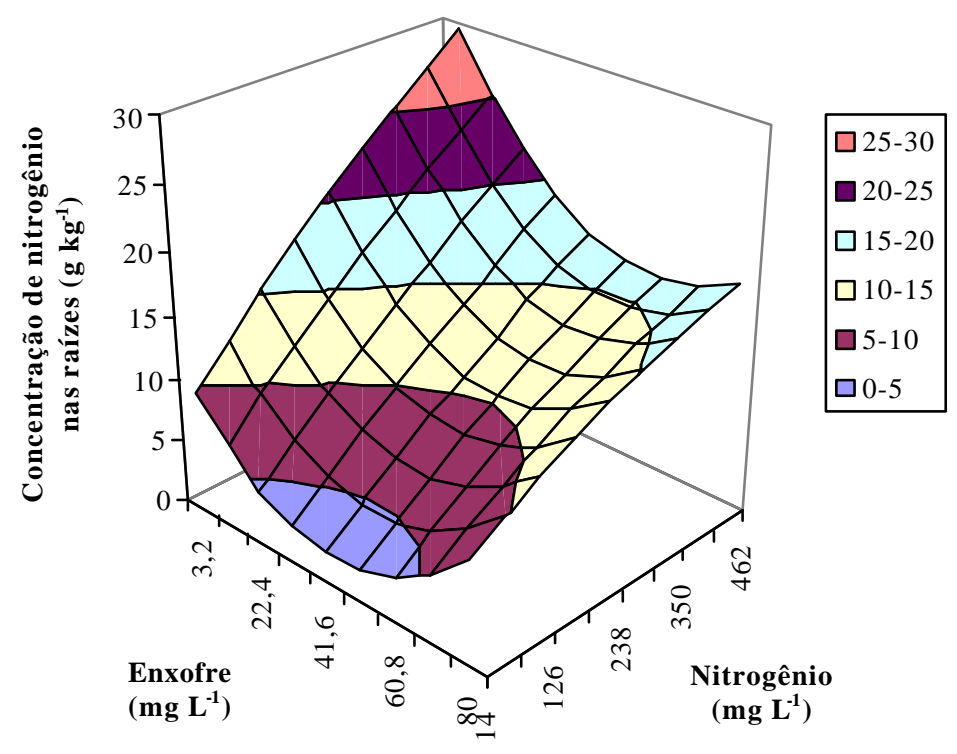

$\mathrm{Y}=9,9956+0,0550 \mathrm{~N}-0,00002 \mathrm{~N}^{2}-0,3796 \mathrm{~S}+0,0044 \mathrm{~S}^{2}-0,0003 \mathrm{NS}\left(\mathrm{R}^{2}=0,82\right)$

Figura 21 - Concentração de nitrogênio nas raízes do capim-Marandu, em função das combinações de doses de nitrogênio com doses de enxofre na solução nutritiva.

Santos (1997) relatou para o capim-Braquiária que a máxima concentração de nitrogênio nas raízes $\left(10,9 \mathrm{~g} \mathrm{~kg}^{-1}\right)$ foi obtida com a dose de nitrogênio de $452 \mathrm{mg} \mathrm{L}^{-1}$ na 
solução nutritiva. Constatou ainda que houve um incremento da concentração de nitrogênio na ordem de duas vezes, quando comparadas a mínima e a máxima concentração deste nutriente nas raízes da forrageira.

Para a concentração de nitrogênio nas raízes do capim-Mombaça, Manarin (2000) observou incremento à medida que se aumentava a dose de nitrogênio na solução nutritiva, relatando que a concentração de nitrogênio variou de 8,2 a $18,6 \mathrm{~g} \mathrm{~kg}^{-1}$, e apresentou ajuste a modelo linear de regressão.

Lavres Júnior (2001) observou que a concentração de nitrogênio nas raízes variou de 10,1 a 16,5 $\mathrm{g} \mathrm{kg}^{-1}$ nas combinações de mais baixa dose de nitrogênio e de potássio à combinação das mais altas doses destes dois nutrientes. A concentração mais elevada deste nutriente foi de $24,5 \mathrm{~g} \mathrm{~kg}^{-1}$ obtida nas doses de nitrogênio e potássio de $462 \mathrm{mg} \mathrm{L}^{-1}$ e $19 \mathrm{mg} \mathrm{L}^{-1}$, respectivamente.

\subsubsection{Concentração de enxofre nas folhas emergentes}

A concentração de enxofre nas folhas emergentes apresentou comportamento diferenciado por ocasião do primeiro e segundo corte do capim-Marandu. A interação entre as doses de nitrogênio e de enxofre não foi significativa $(\mathrm{P}>0,05)$ para a concentração de enxofre nas folhas emergentes na ocasião do primeiro corte e significância também não foi observada $(\mathrm{P}>0,05)$ para as doses individuais de nitrogênio e de enxofre fornecidas na solução nutritiva. Na ocasião do segundo corte verificou-se significância $(\mathrm{P}<0,05)$ para a interação entre as doses de nitrogênio e de enxofre na solução nutritiva, com os resultados ajustando-se ao modelo polinomial de regressão (Figura 22).

O estudo da superfície de resposta da concentração de enxofre nas folhas emergentes, no segundo corte, mostrou a presença de um ponto de sela e desta maneira a concentração máxima de enxofre não pode ser determinada.

De acordo com o modelo polinomial de regressão as mais altas concentrações de enxofre nas folhas emergentes foram observadas nas combinações de mais altas doses de nitrogênio e de enxofre. 
O modelo polinomial de regressão mostrou que as folhas emergentes apresentaram concentração de enxofre variando de 0,86 a $2,08 \mathrm{~g} \mathrm{~kg}^{-1}$, resultado da combinação das mais baixas doses de nitrogênio e enxofre para as mais altas doses desses nutrientes, respectivamente.

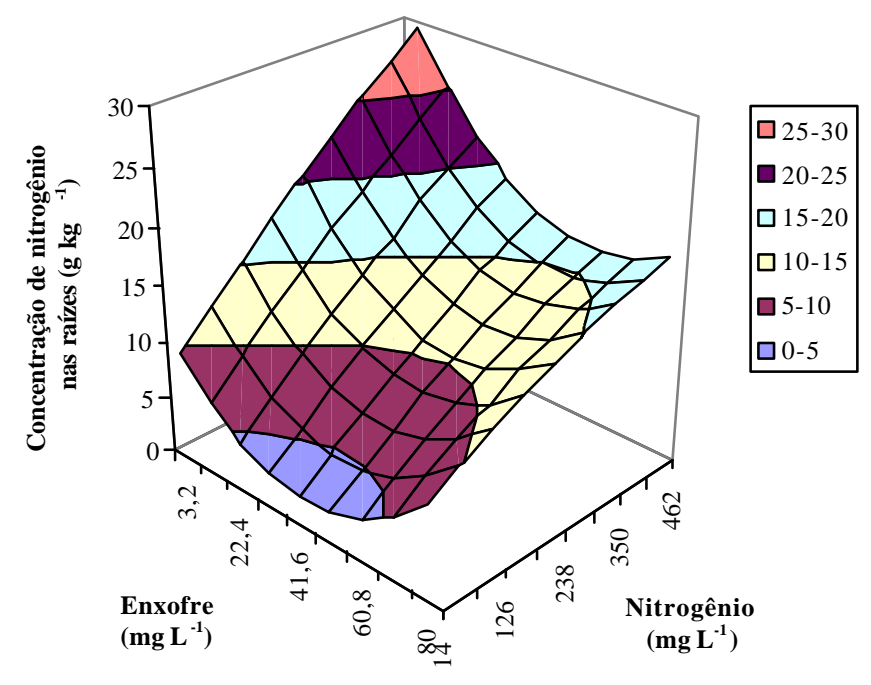

$\mathrm{Y}=11,092+0,0129 \mathrm{~N}, 0,0000003 \mathrm{~N}^{2}+0,0653 S-0,0007 \mathrm{~S}^{2}+0,0001 \mathrm{NS}\left(\mathrm{R}^{2}=0,80\right)$

Figura 22 - Concentração de enxofre nas folhas emergentes do capim-Marandu, na ocasião do segundo corte, em função das combinações de doses de nitrogênio e enxofre na solução nutritiva.

Rodrigues (2002), estudando o capim-Braquiária, observou que a concentração de enxofre nas folhas emergentes no segundo corte apresentou efeito significativo para as doses de nitrogênio, ocorrendo variação na concentração de enxofre no tecido foliar de 0,85 a $2,15 \mathrm{~g} \mathrm{~kg}^{-1}$.

\subsubsection{Concentração de enxofre nas lâminas de folhas recém-expandidas}

$\mathrm{Na}$ análise de variância para a concentração de enxofre nas lâminas de folhas recém-expandidas do capim-Marandu, observou-se significância $(\mathrm{P}<0,05)$ para a 
interação entre as doses de nitrogênio e enxofre fornecidas na solução nutritiva em ambos os cortes. Os resultados ajustaram-se a modelo polinomial de regressão.

O estudo da superfície de resposta da concentração de enxofre nas lâminas de folhas recém-expandidas por ocasião do primeiro corte demonstrou que a dose de nitrogênio de $462 \mathrm{mg} \mathrm{L}^{-1}$ associada a todas as doses de enxofre, resultou na mais elevada concentração de enxofre nas lâminas de folhas recém-expandidas, enquanto a mais baixa concentração de enxofre foi observada nas doses de nitrogênio de 182 a $238 \mathrm{mg} \mathrm{L}^{-1}$ associadas à dose de enxofre de $3,2 \mathrm{mg} \mathrm{L}^{-1}$ (Figura 23). A concentração de enxofre nas lâminas de folhas recém-expandidas, de acordo com o modelo polinomial de regressão, variou de 0,84 a $1,53 \mathrm{~g} \mathrm{~kg}^{-1}$.

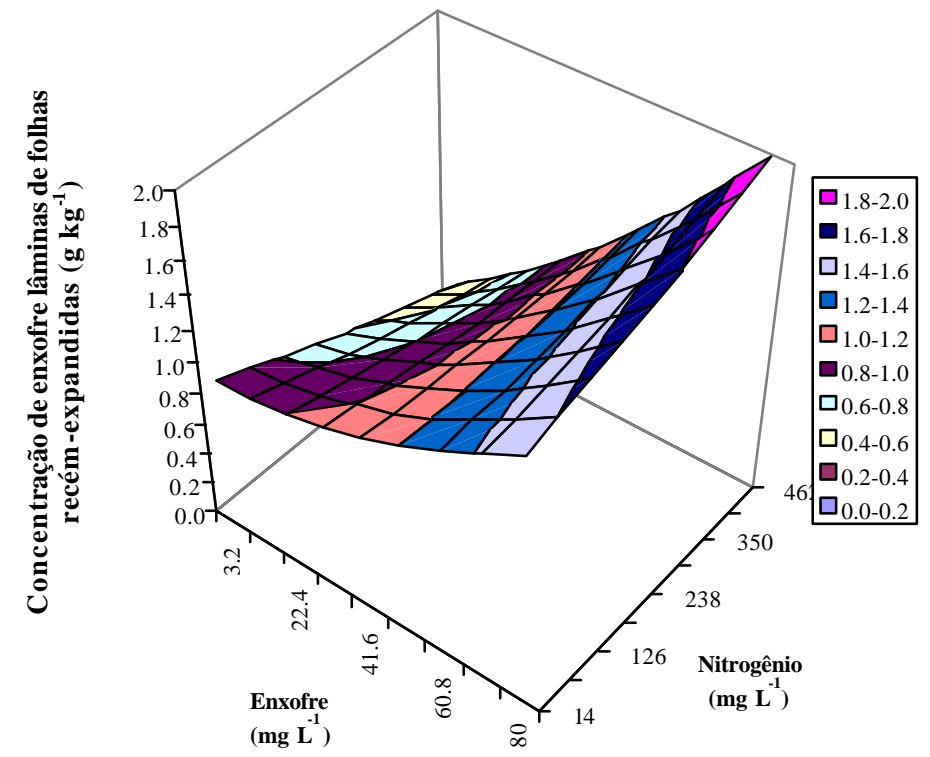

$Y=1,2033-0,0039 N+0,00001 N^{2} 0,0076 S+0,00002 S^{2}-0,00002 N S\left(R^{2}=0,67\right)$

Figura 23 - Concentração de enxofre nas lâminas de folhas recém-expandidas do capim-Marandu, na ocasião do primeiro corte, em função das combinações de doses de nitrogênio e de enxofre na solução nutritiva.

$\mathrm{Na}$ ocasião do primeiro corte, Santos (1997) observou que a máxima concentração de enxofre nas lâminas de folhas recém-expandidas foi de $1,6 \mathrm{~g} \mathrm{~kg}^{-1}$, a 
qual foi obtida na dose de enxofre de $42 \mathrm{mg} \mathrm{L}^{-1}$. Em condições de baixas doses de enxofre no substrato, Santos (1997) verificou que ocorriam as mais elevadas concentrações de enxofre nas lâminas de folhas recém-expandidas e que nas doses de enxofre mais elevadas que $32 \mathrm{mg} \mathrm{L}^{-1}$ na solução nutritiva a concentração de enxofre neste tecido vegetal foi mais baixa quando comparada as demais partes da planta, explicando que isto provavelmente poderia estar ocorrendo pela baixa mobilidade de enxofre no floema, não se redistribuindo de orgãos mais velhos para os mais novos da planta.

Estudando a concentração de enxofre nas lâminas de folhas recém-expandidas do capim-Braquiária na ocasião do primeiro corte, Rodrigues (2002) observou que a variação na concentração desse elemento em função das doses de nitrogênio foi de 1,28 a $2,27 \mathrm{~g} \mathrm{~kg}^{-1}$ resultado da mais baixa para as mais elevada dose de nitrogênio (0 a $\left.1080 \mathrm{mg} \mathrm{kg}^{-1}\right)$.

A análise de variância da concentração de enxofre nas lâminas de folhas recémexpandidas no segundo crescimento demonstrou que a mínima concentração de enxofre ocorreria com uma dose de enxofre fora do intervalo de doses estudadas neste trabalho. O modelo polinomial de regressão demonstrou que no segundo crescimento a concentração de enxofre nas lâminas de folhas recém-expandidas variou de 0,36 a $2,00 \mathrm{~g} \mathrm{~kg}^{-1}$ (Figura 24).

O estudo da superfície de resposta da concentração de enxofre nas lâminas de folhas recém-expandidas demonstrou que as concentrações mais elevadas encontravamse em combinações de altas doses de nitrogênio e de enxofre.

A concentração de enxofre nas lâminas de folhas recém-expandidas por ocasião do segundo corte, na combinação de doses de nitrogênio de $462 \mathrm{mg} \mathrm{L}^{-1}$ e de enxofre de $80 \mathrm{mg} \mathrm{L} \mathrm{L}^{-1}$, foi $52,5 \%$ maior em relação à combinação das mais baixas doses de nitrogênio e de enxofre (nitrogênio de $14 \mathrm{mg} \mathrm{L}^{-1}$ e enxofre de $3,2 \mathrm{mg} \mathrm{L}^{-1}$ ).

$\mathrm{Na}$ ocasião do segundo corte, Santos (1997) observou que a máxima concentração de enxofre $\left(1,8 \mathrm{~g} \mathrm{~kg}^{-1}\right)$ nas folhas recém-expandidas foi obtida na dose de enxofre de $72 \mathrm{mg} \mathrm{L}^{-1}$ na solução nutritiva. 
Paciulli (1997), estudando o efeito de épocas de corte e doses de nitrogênio na composição química de três gramíneas tropicais do gênero Cynodon, observou que tanto aos dois meses como aos seis meses após a primeira adubação nitrogenada, para todas as doses de nitrogênio e para todas as gramíneas, ocorria redução da concentração de enxofre à medida que os cortes foram sendo realizados.

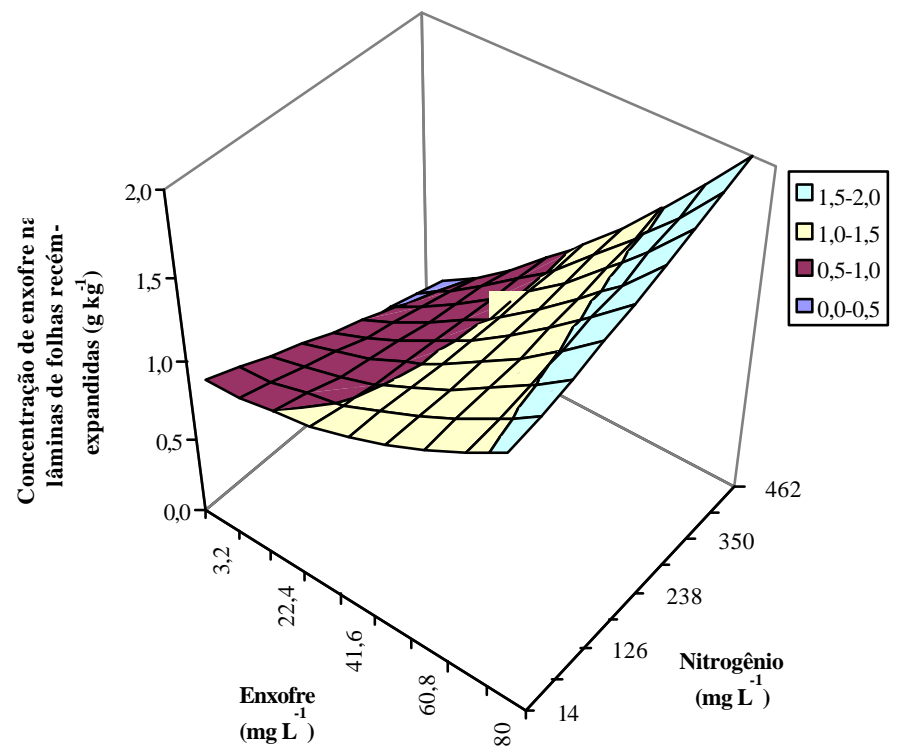

$Y=0,9679-0,0017 \mathrm{~N}+0,000006 \mathrm{~N}^{2}+0,00005 \mathrm{~S}+0,00009 \mathrm{~S}^{2}+0,00003 \mathrm{NS}\left(\mathrm{R}^{2}=0,65\right)$

Figura 24 - Concentração de enxofre nas lâminas de folhas recém-expandidas do capim-Marandu, na ocasião do segundo corte, em função das combinações de doses de nitrogênio e de enxofre na solução nutritiva.

Mattos (2001), no segundo corte do capim-Braquiária proveniente de área não recentemente adubada, observou efeito significativo para o nitrogênio dentro da dose de enxofre de $30 \mathrm{mg} \mathrm{dm}^{-3}$. Para as doses de enxofre dentro de cada dose de nitrogênio, verificou efeito significativo para o enxofre dentro das doses de nitrogênio de 50;100 e $200 \mathrm{mg} \mathrm{dm}^{-3}$. No capim proveniente de área recentemente adubada a concentração de enxofre nas lâminas de folhas recém-expandidas variou significativamente para o nitrogênio dentro das doses de enxofre de 30 e $60 \mathrm{mg} \mathrm{dm}^{-3}$ e significância também foi 
observada para as doses de enxofre dentro das doses de nitrogênio de $0 ; 100$ e $200 \mathrm{mg} \mathrm{dm}^{-1}$.

Rodrigues (2002) observou que a variação na concentração de enxofre no tecido foliar do capim-Braquiária, na ocasião do segundo corte, em função das doses de enxofre dentro das doses de nitrogênio foi de 0,90 a 2,44 $\mathrm{g} \mathrm{kg}^{-1}$, e concluiu que concentrações mais elevadas de enxofre poderiam ser alcançadas com doses de enxofre e nitrogênio mais elevadas que as utilizadas no estudo (enxofre de $216 \mathrm{mg} \mathrm{kg}^{-1}$ nitrogênio de $1080 \mathrm{mg} \mathrm{kg}^{-1}$ de nitrogênio).

\subsubsection{Concentração de enxofre nas lâminas de folhas maduras}

A análise de variância da concentração de enxofre nas lâminas de folhas maduras na ocasião do primeiro corte não demonstrou significância $(\mathrm{P}>0,05)$ para a interação entre doses de nitrogênio e de enxofre. Resposta significativa também não foi observada para as doses individuais de nitrogênio e de enxofre. Essas constatações diferem do que foi observado por Santos (1997) ao estudar o capim-Braquiária submetido a doses de nitrogênio e enxofre na solução nutritiva, que verificou no primeiro corte a máxima concentração de enxofre $\left(1,9 \mathrm{~g} \mathrm{~kg}^{-1}\right)$ na dose de enxofre de $49 \mathrm{mg} \mathrm{L}^{-1}$.

No segundo corte, a concentração de enxofre nas lâminas de folhas maduras apresentou significância $(\mathrm{P}<0,01)$ para a interação entre as doses de nitrogênio e de enxofre fornecidas na solução nutritiva, com os resultados ajustando-se ao modelo polinomial de regressão (Figura 25).

O estudo da superfície de resposta demonstrou a ocorrência de um ponto de sela e deste modo não foi possível a determinação da máxima concentração de enxofre nas lâminas de folhas maduras. As mais elevadas concentrações de enxofre de acordo com a superfície de resposta encontravam-se nas combinações de dose de enxofre de $80 \mathrm{mg} \mathrm{L}^{-1}$, para todas as doses de nitrogênio.

Na ocasião do segundo corte a concentração de enxofre nas lâminas de folhas maduras variou de 0,32 a $2,30 \mathrm{~g} \mathrm{~kg}^{-1}$, sendo que neste corte a concentração de enxofre no tecido foliar foi $48 \%$ mais elevada na combinação de nitrogênio de $462 \mathrm{mg} \mathrm{L}^{-1} \mathrm{e}$ 
enxofre de $80 \mathrm{mg} \mathrm{L}^{-1}$, em relação à combinação de nitrogênio de $14 \mathrm{mg} \mathrm{L}^{-1}$ e enxofre de $3,2 \mathrm{mg} \mathrm{L}^{-1}$.

Nas lâminas de folhas maduras do capim-Braquiária, na ocasião do segundo corte, Santos (1997) relatou que a máxima concentração de enxofre foi de $2,0 \mathrm{~g} \mathrm{~kg}^{-1}$, obtida na dose de enxofre de $42 \mathrm{mg} \mathrm{L}^{-1}$. Ainda segundo Santos (1997), as plantas quando submetidas à dose de enxofre inferior a $64 \mathrm{mg} \mathrm{L}^{-1}$ apresentavam concentração mais elevada desse nutriente nas lâminas de folhas velhas, comportamento que pode ser justificado pela baixa mobilidade do elemento no floema, não o translocando suficientemente para suprir os òrgãos mais novos da forrageira.

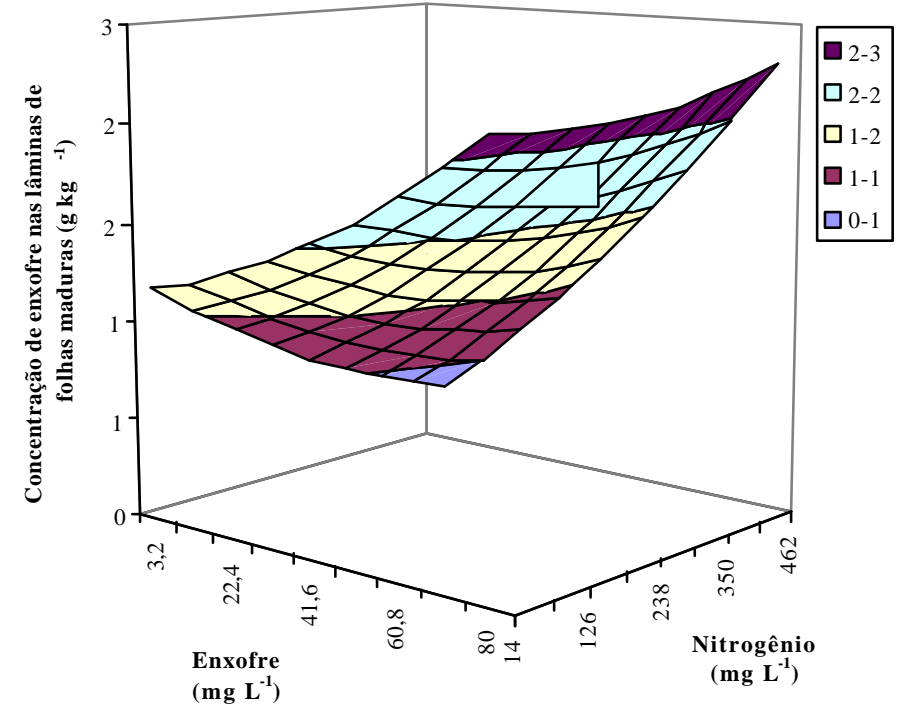

$Y=1,2147-0,0030 N+0,000002 N^{2}+0,0045 S+0,00009 S^{2}+0,00003 N S\left(R^{2}=0,60\right)$

Figura 25 - Concentração de enxofre nas lâminas de folhas maduras do capimMarandu, na ocasião do segundo corte, em função das combinações de doses de nitrogênio e de enxofre na solução nutritiva. 


\subsubsection{Concentração de enxofre nos colmos + bainhas}

Para a concentração de enxofre nos colmos + bainhas não se observou interação significativa entre as doses de nitrogênio e de enxofre no primeiro e segundo cortes. Resposta significativa também não foi observada $(\mathrm{P}>0,05)$ para as doses individuais de nitrogênio e de enxofre, na ocasião do primeiro corte. Resultados diferentes foram obtidos por Santos (1997) no capim-Braquiária submetido a doses de nitrogênio e de enxofre na solução nutritiva, onde observou que a máxima concentração de enxofre nos colmos + bainhas foi de $2,1 \mathrm{~g} \mathrm{~kg}^{-1}$ quando a dose de enxofre foi de $65 \mathrm{mg} \mathrm{L}^{-1}$ na solução nutritiva.

No segundo corte observou-se resposta significativa para as doses de nitrogênio fornecidas na solução nutritiva, com ajuste dos resultados a modelo quadrático de regressão (Figura 26). Pela equação obtida ficou demonstrado que a dose de nitrogênio de $337,5 \mathrm{mg} \mathrm{L}^{-1}$ foi a responsável pela mais baixa concentração de enxofre nos colmos+bainhas, provavelmente por efeito de diluição. A concentração de enxofre nos colmos + bainhas variou de $0,66 \mathrm{~g} \mathrm{~kg}^{-1}$ a $2,8 \mathrm{~g} \mathrm{~kg}^{-1}$.

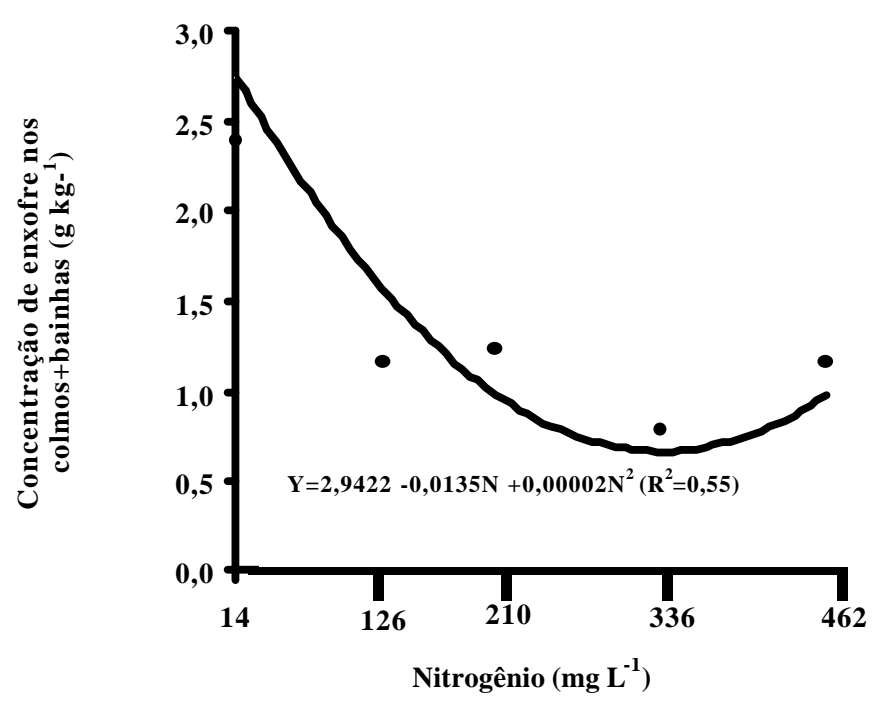

Figura 26 - Concentraçao de enxotre nos colmos + bainnas do capim-Marandu na ocasião do segundo corte, em função das doses de nitrogênio na 
Santos (1997), trabalhando com capim-Braquiária submetido a doses de nitrogênio e enxofre na solução nutritiva, verificou que a máxima concentração de enxofre nos colmos + bainhas foi de $1,7 \mathrm{~g} \mathrm{~kg}^{-1}$ e foi obtida na dose de enxofre de $61 \mathrm{mg} \mathrm{\textrm {L } ^ { - 1 }}$ fornecida na solução nutritiva. Quando se comparou os valores mínimo e máximo da concentração de enxofre naquele capim nos colmos+bainhas constatou-se um incremento dessa concentração da ordem de três vezes.

\subsubsection{Concentração de enxofre nas raízes}

$\mathrm{Na}$ análise de variância para a concentração de enxofre nas raízes do capimMarandu, não se observou significância $(\mathrm{P}>0,05)$ para a interação entre as doses de nitrogênio e as de enxofre na solução nutritiva. Entretanto observou-se significância $(\mathrm{P}<0,05)$ para as doses individuais de nitrogênio fornecidas na solução nutritiva, com os resultados tendo ajuste a modelo linear de regressão (Figura 27). Constatou-se, através da equação de primeiro grau que à medida que se aumentou a dose de nitrogênio na solução nutritiva ocorreu redução da concentração de enxofre nas raízes.

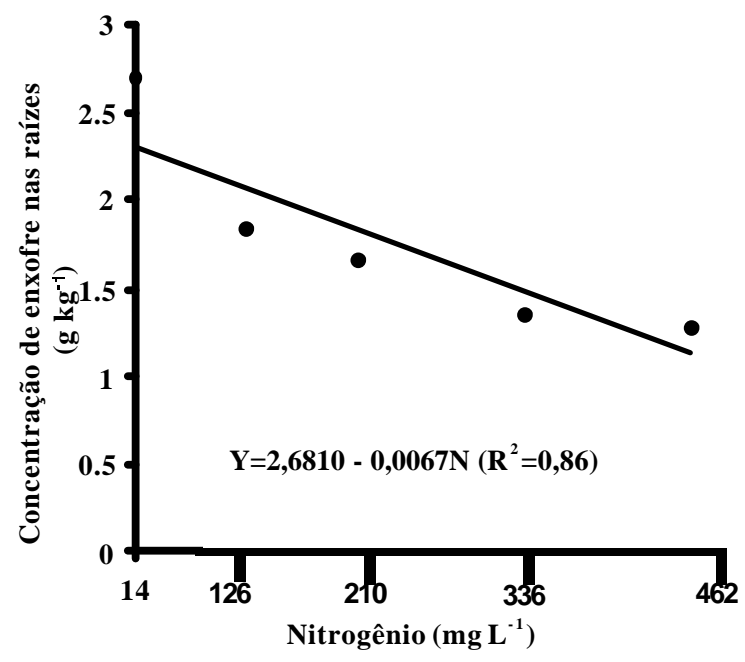

Figura 27 - Concentração de enxofre nas raízes do capim-Marandu, em função das doses de nitrogênio na solução nutritiva. 
De acordo com a equação de primeiro grau (Figura 27) a dose de nitrogênio de $14 \mathrm{mg} \mathrm{L} \mathrm{L}^{-1}$ promoveu a maior concentração de enxofre nas raízes $\left(2,68 \mathrm{~g} \mathrm{~kg}^{-1}\right)$. Em condições de altas doses de nitrogênio ocorria mais baixa concentração de enxofre nas raízes, situação esta que pode ser devida ao efeito de diluição.

Santos (1997) verificou que a concentração de enxofre nas raízes do capim-Braquiária variou significativamente com as doses de enxofre na solução nutritiva e a dose de $72 \mathrm{mg} \mathrm{L}^{-1}$ foi a que resultou na máxima concentração de enxofre nas raízes. Ressaltou ainda que esse resultado mostra um incremento de três vezes na quantidade de enxofre quando se compara a mínima e a máxima concentração desse nutriente nesta parte da planta.

\subsubsection{Concentração de fósforo nas lâminas de folhas recém-expandidas}

A concentração de fósforo nas lâminas de folhas recém-expandidas apresentou comportamento diferenciado entre o primeiro e segundo corte. No primeiro corte não se observou interação significativa $(\mathrm{P}>0,05)$ para as combinações de doses de nitrogênio e de enxofre na solução nutritiva. Entretanto observou-se significância $(\mathrm{P}<0,01)$ para as doses de nitrogênio empregadas na solução nutritiva, ajustando-se os resultados ao modelo linear de regressão (Figura 28). No segundo corte a análise de variância revelou significância $(\mathrm{P}<0,05)$ para a interação entre as doses de nitrogênio e de enxofre fornecidas na solução nutritiva, com ajuste dos resultados ao modelo polinomial de regressão.

No primeiro corte do capim-Marandu, de acordo com o modelo linear de regressão, na dose de nitrogênio de $14 \mathrm{mg} \mathrm{L}^{-1}$ ocorreu a mais elevada concentração de fósforo nas folhas recém-expandidas do capim $\left(5,20 \mathrm{~g} \mathrm{~kg}^{-1}\right)$ enquanto que na dose de nitrogênio de $462 \mathrm{mg} \mathrm{L}^{-1}$ foi observada a mais baixa concentração de fósforo $\left(0,20 \mathrm{~g} \mathrm{~kg}^{-1}\right)$.

Ao analisar-se a Figura 29, pode-se observar que as mais altas concentrações de fósforo nas lâminas de folhas recém-expandidas no segundo corte encontravam-se em combinações de baixa dose de nitrogênio $\left(14 \mathrm{mg} \mathrm{L}^{-1}\right)$ e altas doses de enxofre $(60,8 \mathrm{a}$ 
$80 \mathrm{mg} \mathrm{L}^{-1}$ ) e as mais baixas concentrações na combinação de doses de nitrogênio de 294 a $350 \mathrm{mg} \mathrm{L}^{-1}$ associada às doses de enxofre de $41,6 \mathrm{a} 51,2 \mathrm{mg} \mathrm{L}^{-1}$.

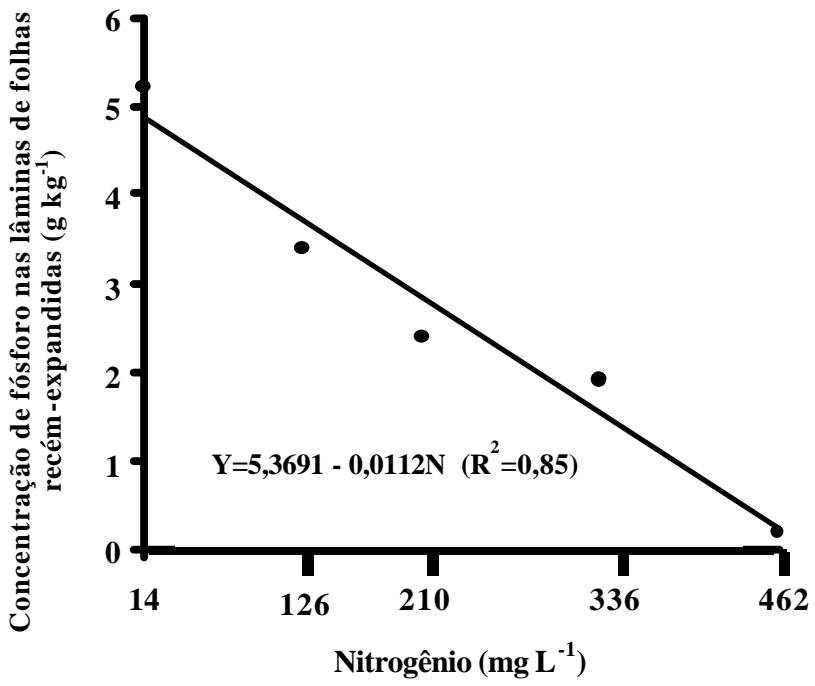

Figura 28 - Concentraçāo de tostoro nas lämınas de tolhas recem-expandidas do capimMarandu, na ocasião do primeiro corte, em função das doses de nitrogênio na solução nutritiva.

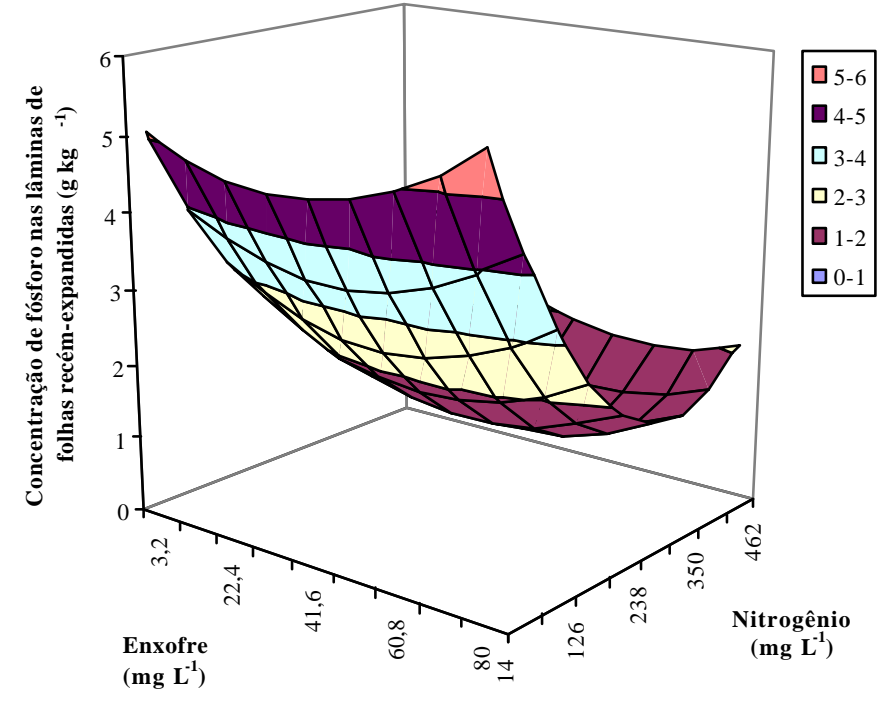

$$
Y=5,5046-0,0230 N+0,00004 N^{2}-0,0338 S+0,0005 S^{2}-0,00005 N S\left(R^{2}=0,81\right)
$$

Figura 29 - Concentração de fósforo nas lâminas de folhas recém-expandidas do capim-Marandu, na ocasião do segundo corte, em função das combinações de doses de nitrogênio e de enxofre na solução nutritiva. 
Cedeño (2001), estudando gramíneas forrageiras tropicais em várias idades de crescimento, verificou que independentemente da espécie, as concentrações de fósforo decresceram com o avanço da idade de crescimento, sendo observados os valores de 1,1 a $0,7 \mathrm{~g} \mathrm{~kg}^{-1}$ para 28 e 70 dias de crescimento.

\subsubsection{Concentração de potássio nas lâminas de folhas recém-expandidas}

Para a concentração de potássio nas lâminas de folhas recém-expandidas não se observou interação significativa $(\mathrm{P}>0,05)$ entre as doses de nitrogênio e de enxofre, em ambos os cortes. Significância também não foi observada $(\mathrm{P}>0,05)$ individualmente para as doses de nitrogênio e enxofre, no primeiro corte. Na ocasião do segundo corte observou-se significância $(\mathrm{P}<0,01)$ para as doses de nitrogênio fornecidas na solução nutritiva, ajustando os resultados ao modelo quadrático de regressão (Figura 30).

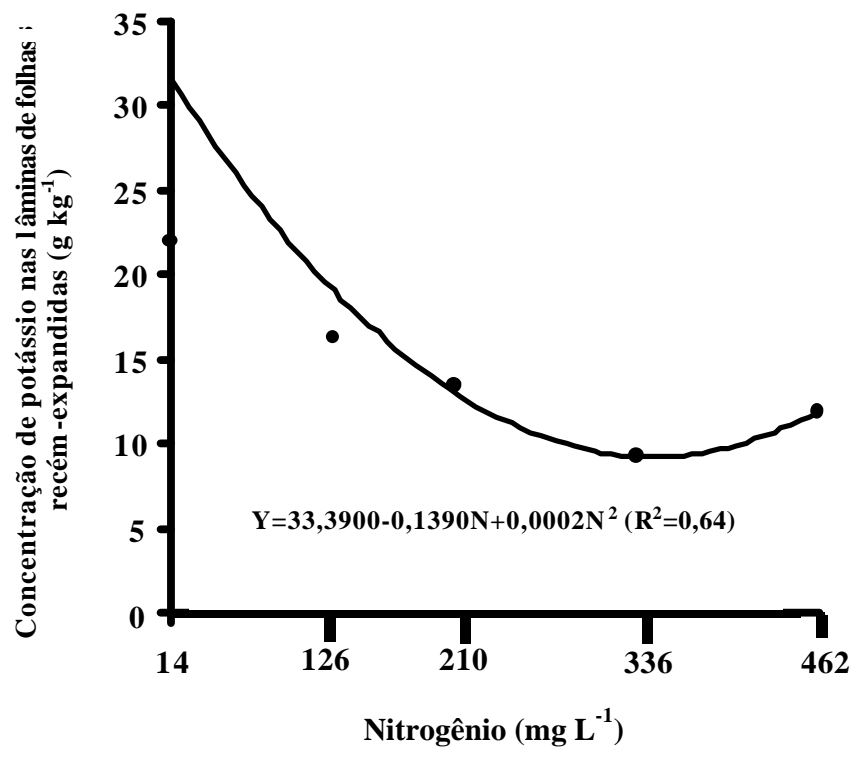

Figura 30 - Concentração de potássio nas lâminas de folhas recém-expandidas do capim-Marandu, na ocasião do segundo corte, em função das doses de nitrogênio na solução nutritiva.

De acordo com a equação de segundo grau, o nitrogênio na solução em $347,5 \mathrm{mg} \mathrm{L}^{-1}$ correspondeu ao ponto de mínima concentração de potássio $\left(9,2 \mathrm{~g} \mathrm{~kg}^{-1}\right)$ nas lâminas de folhas recém-expandidas e à medida em que se aumentou as doses de 
nitrogênio na solução nutritiva ocorreu redução na concentração de potássio no tecido vegetal. A concentração de potássio nas lâminas de folhas recém-expandidas, na ocasião do segundo corte, variou de 9,2 a 31,5 $\mathrm{g} \mathrm{kg}^{-1}$.

Discordando do que foi obtido neste estudo, foi observado por Paciulli (1997) num trabalho referente a épocas de corte e doses de nitrogênio na composição química de três gramíneas tropicais, que a concentração de potássio aumentou com as doses de nitrogênio e para todas as gramíneas aos dois e aos seis meses após a primeira adubação nitrogenada.

Cedeño (2001) observou que a concentração de potássio decresceu com o avanço da idade de rebrota, estimando-se que aos 49 dias de crescimento, ocorria a concentração mínima de potássio $\left(8,6 \mathrm{~g} \mathrm{~kg}^{-1}\right)$. As concentrações médias de potássio diferiram entre as idades de crescimento das três gramíneas, mas quando não considerou as idades de corte, as concentrações de potássio na massa seca dos capins Coastcross, Tifton 68 e Tifton 85 não diferiram entre si $\left(9,4 ; 10,3\right.$ e $\left.10,1 \mathrm{~g} \mathrm{~kg}^{-1}\right)$.

\subsubsection{Concentração de cálcio nas lâminas de folhas recém-expandidas}

A concentração de cálcio nas lâminas de folhas recém-expandidas apresentou comportamento diferenciado entre o primeiro e segundo corte. No pimeiro corte não se observou interação significativa $(\mathrm{P}>0,05)$ entre as doses de nitrogênio e de enxofre na solução nutritiva. A análise de variância mostrou significância $(\mathrm{P}<0,01)$ para as doses de enxofre, fornecidas no substrato com os resultados ajustando-se ao modelo quadrático de regressão (Figura 31). No segundo corte, a análise de variância apresentou significância $(\mathrm{P}<0,01)$ para a interação entre as doses de nitrogênio e de enxofre na solução nutritiva.

Através da equação de segundo grau verificou-se, no primeiro corte, que a dose de enxofre de $45,7 \mathrm{mg} \mathrm{L}^{-1}$ promoveu a máxima concentração de cálcio nas lâminas de folhas recém-expandidas. A concentração de cálcio nas lâminas de folhas recémexpandidas variou de 3,0 a $6,8 \mathrm{~g} \mathrm{~kg}^{-1}$. 


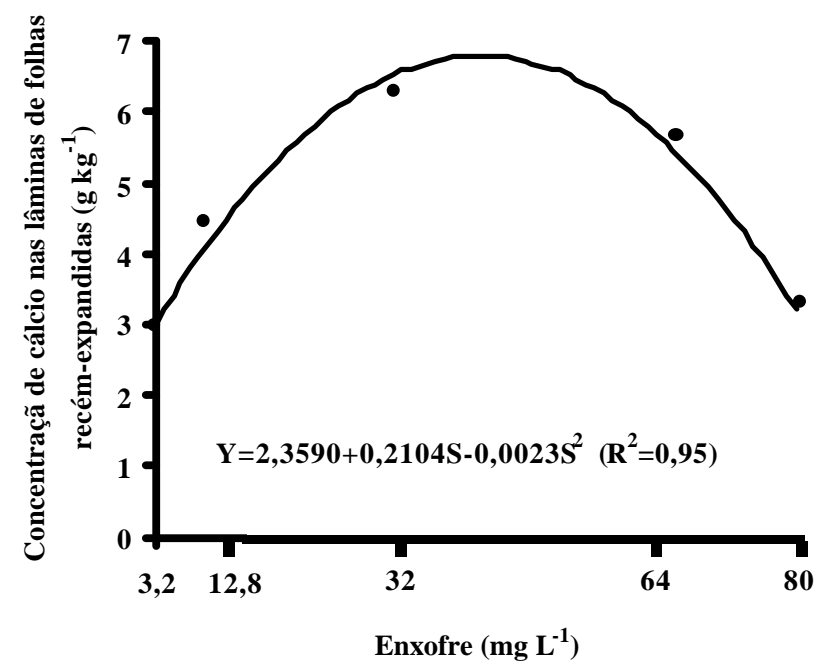

Figura 31 - Concentração de cálcio nas lâminas de folhas recém-expandidas do capim-Marandu, na ocasião do primeiro corte, em função das doses de enxofre na solução nutritiva.

No segundo corte, a concentração de cálcio nas lâminas de folhas recémexpandidas variou em consonância ao suprimento conjunto de nitrogênio e de enxofre (Figura 32), variação esta expressada em modelo polinomial.

Pela análise da superfície de resposta observou-se que na dose de nitrogênio de $533,4 \mathrm{mg} \mathrm{L}^{-1}$ ( excedente à máxima utilizada no experimento) associada a dose de enxofre de $55,5 \mathrm{mg} \mathrm{L}^{-1}$ ocorreria a mais elevada concentração de cálcio no tecido.

A superficíe de resposta da concentração de cálcio mostrou que as concentrações mais altas deste nutriente encontravam-se nas combinações de dose de nitrogênio de $462 \mathrm{mg} \mathrm{L}^{-1}$ associada as doses de enxofre de 41,6 a 60,8 $\mathrm{mg} \mathrm{L}^{-1}$, sendo as mais baixas concentrações de cálcio encontradas nas doses de nitrogênio de 238 a $350 \mathrm{mg} \mathrm{L}^{-1}$ associadas a dose de enxofre de $3,2 \mathrm{mg} \mathrm{L}^{-1}$.

Paciulli (1997), estudando a concentração de cálcio em três gramíneas tropicais observou aumento na concentração de cálcio aos dois e aos seis meses após a primeira adubação nitrogenada, para todas as doses de nitrogênio e gramíneas estudadas. 


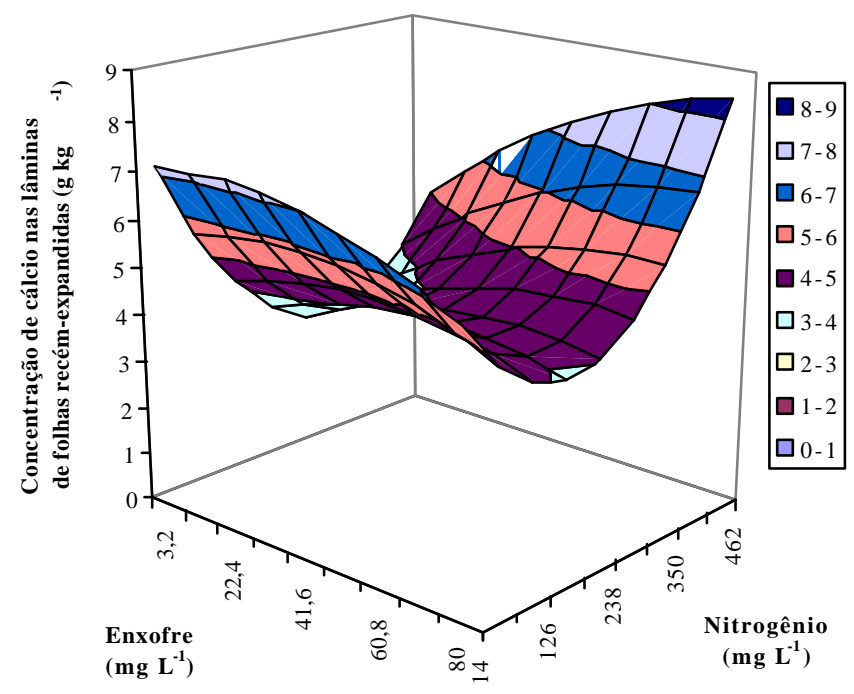

$Y=7,5752-0,03375 N+0,00006 N^{2}+0,0125 S-0,0004 S^{2}+0,0001 N S\left(R^{2}=0,50\right)$

Figura 32 - Concentração de cálcio nas lâminas de folhas recém-expandidas do capim-Marandu, na ocasião do segundo corte, em função das combinações de doses de nitrogênio e de enxofre na solução nutritiva.

\subsubsection{Concentração de magnésio nas lâminas de folhas recém-expandidas}

Para a concentração de magnésio nas lâminas de folhas recém-expandidas, não foi significativa $(\mathrm{P}>0,05)$ a interação entre as doses de nitrogênio e de enxofre na solução nutritiva, em ambos os cortes da gramínea. No entanto, observou-se significância $(\mathrm{P}<0,05)$ para as doses de enxofre na ocasião do primeiro corte (Figura 33) e significância $(\mathrm{P}<0,01)$ para as doses de nitrogênio, na ocasião do segundo corte, ajustando-se a equação de segundo grau (Figura 34).

De acordo com a equação de segundo grau, a dose de enxofre de $76,3 \mathrm{mg} \mathrm{L}^{-1}$ resultou em mais alta concentração de magnésio no tecido vegetal $\left(3,3 \mathrm{~g} \mathrm{~kg}^{-1}\right)$, e a dose de enxofre de $3,2 \mathrm{mg} \mathrm{L}^{-1}$ na solução nutritiva resultou na mais baixa concentração $\left(2,2 \mathrm{~g} \mathrm{~kg}^{-1}\right)$, na ocasião do primeiro corte. 


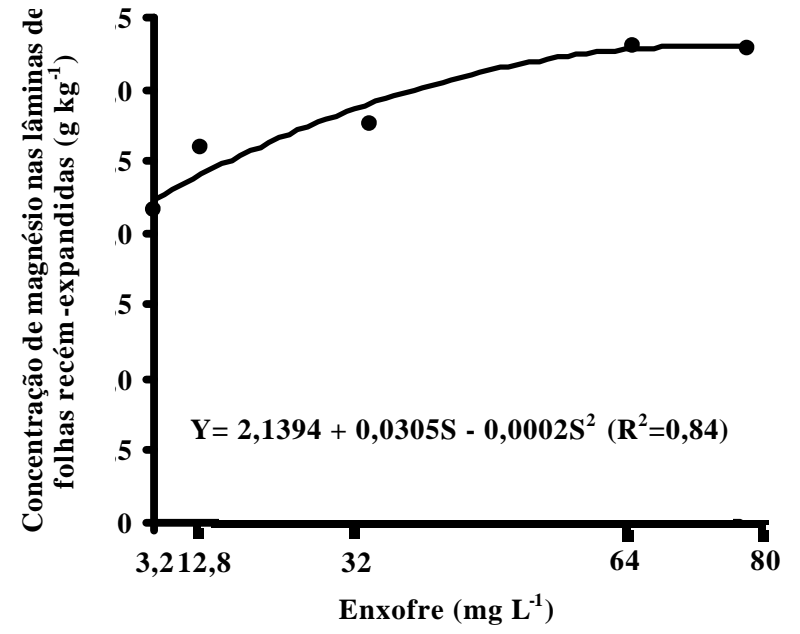

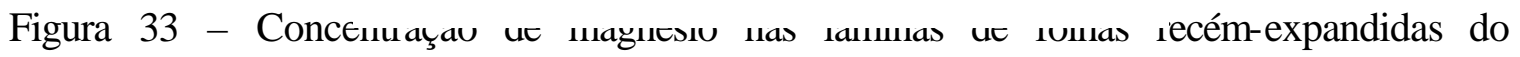
capim-Marandu, na ocasião do primeiro corte, em função das doses de enxofre na solução nutritiva.

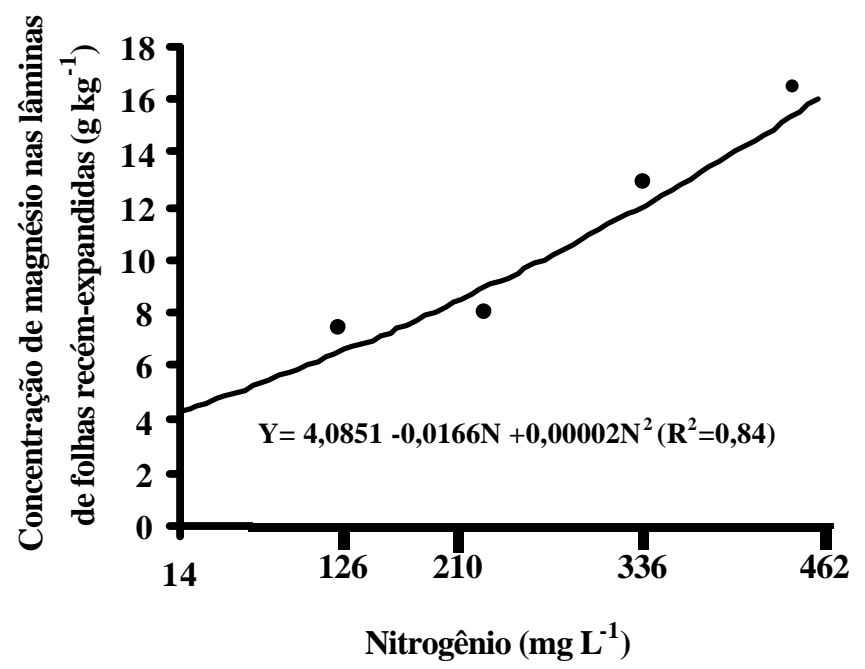

Figura 34 - Concentração de magnésio nas lâminas de folhas recém-expandidas do capim-Marandu na ocasião do segundo corte, em função das doses de nitrogênio na solução nutritiva. 
Cedeño (2001) ao estudar a concentração de magnésio em forrageiras tropicais, considerando idades de crescimento, observou a redução nessa concentração de magnésio com o avanço das idades de corte das gramíneas, estando a concentração mínima estimada em $0,9 \mathrm{~g} \mathrm{~kg}^{-1}$ aos 49 dias de idade.

\subsection{Relação N:S na planta}

\subsubsection{Relação N:S nas folhas emergentes}

$\mathrm{Na}$ análise de variância para a relação $\mathrm{N}: \mathrm{S}$ nas folhas emergentes do capim-Marandu, verificou-se significância $(\mathrm{P}<0,01)$ para a interação entre as doses de nitrogênio e de enxofre na solução nutritiva, para o primeiro corte, e significância $(\mathrm{P}<0,05)$ para a interação entre essas doses no segundo corte.

A relação N:S nas folhas emergentes, na ocasião do primeiro corte, tem ajuste ao modelo polinomial de regressão e a ocorrência de um ponto de sela que impossibilitou a determinação da máxima ou mínima relação $\mathrm{N}: \mathrm{S}$ nesta parte da planta. A relação $\mathrm{N}: \mathrm{S}$ nas folhas emergentes, na ocasião do primeiro corte do capim-Marandu, variou de 9,3:1 a 34,6:1 (Figura 35). Essa relação N:S de 34,6:1 indica deficiência acentuada de enxofre no capim, e por outro lado a relação $\mathrm{N}: \mathrm{S}$ de 9,3:1 indica até excesso de enxofre. Em geral, a relação adequada de N:S nos capins varia de 13:1 a 14:1 (Werner \& Monteiro, 1988).

A superfície de resposta da relação N:S mostrou que os valores mais elevados encontram-se nas combinações de doses de nitrogênio de 350 a $462 \mathrm{mg} \mathrm{L}^{-1}$ e de enxofre de 3,2 a $12,8 \mathrm{mg} \mathrm{L}^{-1}$, enquanto que as menores relações $\mathrm{N}: \mathrm{S}$ encontram-se nas combinações de doses de nitrogênio de $14 \mathrm{mg} \mathrm{L}^{-1}$ e de enxofre de 12,8 a 41,6 $\mathrm{mg} \mathrm{L}^{-1}$.

$\mathrm{O}$ estudo da superfície de resposta da relação $\mathrm{N}: \mathrm{S}$ nas folhas emergentes na ocasião do primeiro corte demonstrou que, para uma mesma dose de nitrogênio, à medida em que se aumentou a dose de enxofre na solução nutritiva ocorreu redução na relação N:S, mesmo em condições de altas doses de nitrogênio. 
Santos (1997) relatou que no primeiro corte do capim-Braquiária os valores da relação $\mathrm{N}: \mathrm{S}$ nas folhas emergentes apresentaram as mais baixas variações entre 8,2:1 (o menor) e 15,7:1 (o maior valor ) para essa relação, em função do incremento de enxofre na solução nutritiva.

No segundo corte a relação N:S nas folhas emergentes do capim-Marandu ajustou-se ao modelo polinomial de regressão, e também apresentou ponto de sela impossibilitando a determinação da máxima ou mínima relação $\mathrm{N}: \mathrm{S}$ neste tecido foliar. A relação N:S nestas folhas variou de 6,8:1 a 30,2:1 (Figura 36).

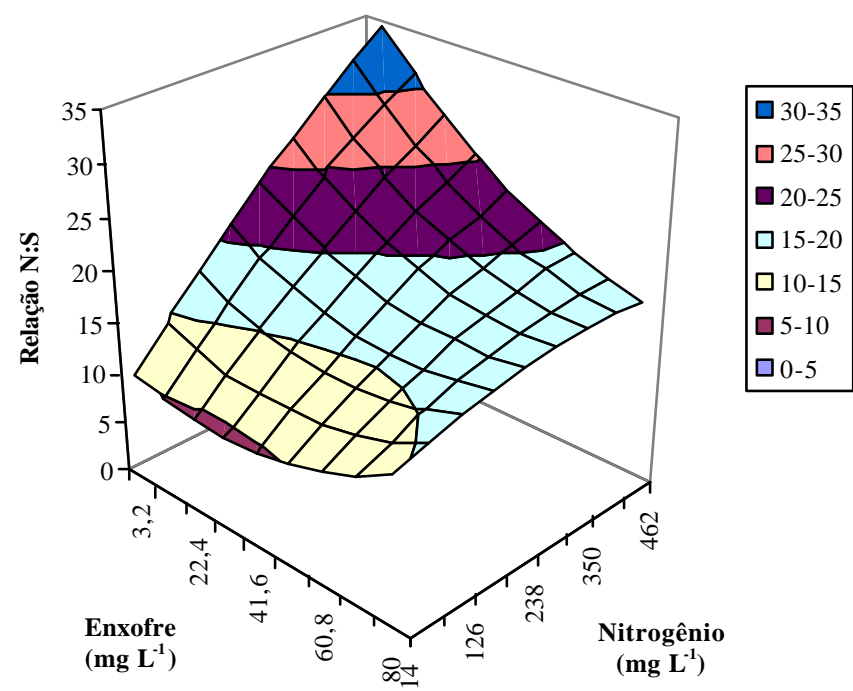

$$
Y=10,1810+0,0693 N-0,00003 N^{2}-0,1181 S+0,0021 S^{2}-0,0006 N S\left(R^{2}=0,45\right)
$$

Figura 35 - Relação N:S nas folhas emergentes do capim-Marandu, na ocasião do primeiro corte, em função das combinações de doses de nitrogênio e de enxofre na solução nutritiva.

A superfície de resposta da relação $\mathrm{N}: \mathrm{S}$ nas folhas emergentes na ocasião do segundo corte mostrou que os valores mais elevados da relação N:S encontravam-se na faixa de nitrogênio de 238 a $462 \mathrm{mg} \mathrm{L}^{-1}$ e de enxofre de 3,2 a $12,8 \mathrm{mg} \mathrm{L}^{-1}$ e que as mais baixas relações N:S encontravam-se nas combinações de doses de nitrogênio de 14 a 70 $\mathrm{mg} \mathrm{L}^{-1}$ com doses de enxofre de 41,6 a 70,4 $\mathrm{mg} \mathrm{L}^{-1}$.

Santos (1997), avaliando a relação N:S nas folhas emergentes, no segundo corte do capim-Braquiária, observou que nas doses de enxofre de 32 a $64 \mathrm{mg} \mathrm{L}^{-1}$ eram obtidos 
valores de relação $\mathrm{N}: \mathrm{S}$ de 10:1 e 12:1. Esta faixa relatada pelo autor situa-se abaixo da faixa de 13:1 a 14:1 adequada para capins.

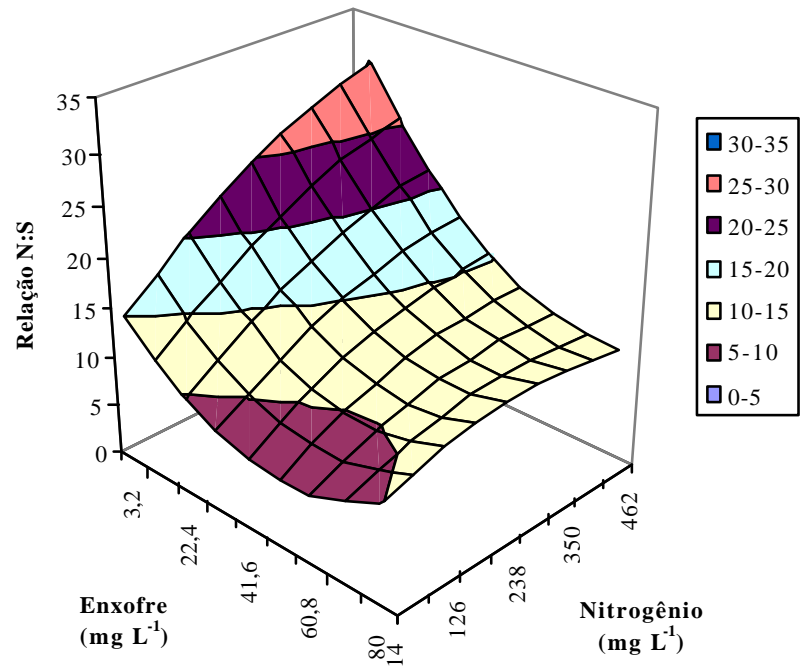

$Y=15,4781+0,0540 N+0,00004 N^{2}-0,3634 S+0,0036 S^{2}-0,0004 N S\left(R^{2}=0,73\right)$

Figura 36 - Relação N:S nas folhas emergentes do capim-Marandu, na ocasião do segundo corte, em função das combinações de doses de nitrogênio com doses de enxofre fornecidas na solução nutritiva.

\subsubsection{Relação N:S nas lâminas de folhas recém-expandidas}

$\mathrm{O}$ comportamento da relação $\mathrm{N}: \mathrm{S}$ nas lâminas de folhas recém-expandidas foi diferente entre o primeiro e o segundo corte do capim-Marandu. No primeiro corte a relação $\mathrm{N}: \mathrm{S}$ não mostrou significância $(\mathrm{P}>0,05)$ para a interação entre as combinações de doses de nitrogênio e de enxofre. Na ocasião do segundo corte a relação N:S apresentou significância $(\mathrm{P}<0,05)$ para a interação entre as doses de nitrogênio e de enxofre na solução nutritiva.

No primeiro crescimento, Santos (1997), trabalhando com capim-Braquiária, encontrou resultados diferentes aos observados neste trabalho, já que as lâminas de 
folhas recém-expandidas apresentavam alta variação (2,5 vezes) entre os mais baixos e os mais altos valores da relação N:S.

Os valores da relação N:S nas lâminas de folhas recém-expandidas, no segundo corte, mostraram ajuste ao modelo polinomial de regressão e a presença de um ponto de sela que impossibilitou a determinação da mínima ou máxima relação N:S (Figura 37). A relação N:S nas lâminas de folhas recém-expandidas variou de 2,8:1 a 37,2:1, extremos estes inadequados para gramíneas segundo Dijkshoorn \& Van Wijk (1967), que propuseram para gramíneas em geral a relação de 13,7: 1.

Woodhouse (1967), trabalhando durante vários anos com grama-bermuda (Cynodon dactylon), sugeriu como valores adequados à nutrição deste capim relações $\mathrm{N}: \mathrm{S}$ entre $12: 1$ e $17: 1$.

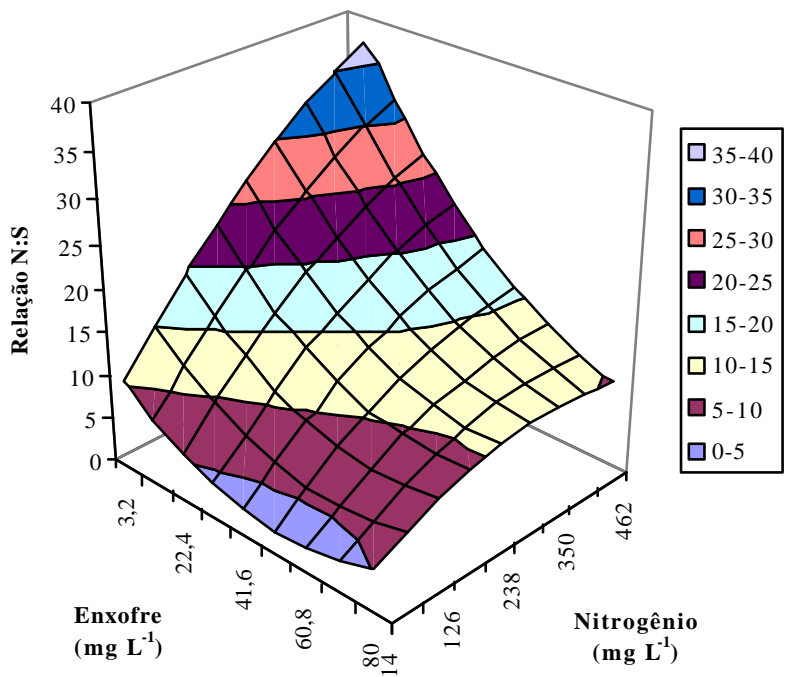

$Y=10,0633+0,0906 N-0,00006 N^{2}-0,3164 S+0,0031 S^{2}-0,0006 N S\left(R^{2}=0,77\right)$

Figura 37 - Relação N:S nas folhas recém-expandidas do capim-Marandu, na ocasião do segundo corte, em função das combinações de doses de nitrogênio e de enxofre na solução nutritiva.

A análise da superfície de resposta das folhas recém-expandidas no segundo corte mostrou que as maiores relação N:S encontravam-se nas combinações de doses de nitrogênio de 406 a $462 \mathrm{mg} \mathrm{L}^{-1}$ com as doses de enxofre de 3,2 a $12,8 \mathrm{mg} \mathrm{L}^{-1}$. 
Nas lâminas de folhas recém-expandidas do capim-Braquiária, Santos (1997) também ressaltou, por ocasião do segundo corte, que no intervalo das doses de enxofre de 32 a $64 \mathrm{mg} \mathrm{L}^{-1}$ foram detectados valores de relação $\mathrm{N}: \mathrm{S}$ próxima a faixa de 10:1 a $12: 1$.

Monteiro \& Carriel (1987), trabalhando com capim-Colonião num solo arenoso de Brotas, observaram que a relação N:S variou entre 16,9:1 e 4,7:1 por ocasião do primeiro corte e 29:1 e 2,8:1 à época do segundo corte. Concluíram que um mínimo de enxofre de 30 a $40 \mathrm{~kg} \mathrm{ha}^{-1}$ se mostrou necessário para que o capim-Colonião apresentasse uma concentração mínima de enxofre de 0,8 a $1,2 \mathrm{~g} \mathrm{~kg}^{-1}$ e uma relação $\mathrm{N}: \mathrm{S}$ de $13,7: 1$.

Monteiro (1986), estudando a relação N:S em uma área com capim-Pensacola + trevo-branco na presença ou ausência de aplicação de enxofre, observou com o decorrer dos anos redução na relação $\mathrm{N}: \mathrm{S}$ de 16,9:1 a 3,5:1.

\subsubsection{Relação N:S nas lâminas de folhas maduras}

A análise de variância para a relação $\mathrm{N}: \mathrm{S}$ nas lâminas de folhas maduras, em ambos os cortes, revelou interação significativa $(\mathrm{P}<0,01)$ entre as doses de nitrogênio e de enxofre na solução nutritiva.

No primeiro corte a relação $\mathrm{N}: \mathrm{S}$ nas lâminas de folhas maduras ajustou-se ao modelo polinomial de regressão, e encontrou-se um ponto de sela . (Figura 38). A relação N:S variou de -0,94:1 a 18,3:1 indicando portanto claramente a deficiência de nitrogênio, e confirmando o que era observado visualmente nas plantas, na casa-devegetação. A superfície de resposta mostrou que, para uma mesma dose de nitrogênio associada a incrementos nas doses de enxofre, ocorria redução na relação N:S. Esse fato pode ser explicado pela mobilidade ou não desses elementos dentro da planta, ou seja, como o nitrogênio é móvel ele estaria deslocando-se para as partes mais novas e o contrário estaria ocorrendo com o enxofre por ser muito pouco móvel dentro da planta.

A análise da superfície de resposta da relação N:S nas folhas maduras, no

primeiro corte, demonstrou que os valores mais elevados da relação N:S foram 
observados nas combinações de doses de nitrogênio de 238 a $350 \mathrm{mg} \mathrm{L}^{-1}$ associadas às doses de enxofre de 3,2 $\mathrm{mg} \mathrm{L}^{-1}$ e as mais baixas relações $\mathrm{N}: \mathrm{S}$ foram observadas na dose de nitrogênio de $14 \mathrm{mg} \mathrm{L}^{-1}$ associada às doses de enxofre de 60,8 a $80 \mathrm{mg} \mathrm{L}^{-1}$.

Estudando a relação N:S nas lâminas de folhas maduras, Santos (1997) observou que apresentavam a mais alta variação (5,3 vezes) entre o mais baixo e os mais alto valor dessa relação do capim-Braquiária, na ocasião do primeiro corte. No presente trabalho essa variação foi de 3 vezes.

$\mathrm{Na}$ ocasião do segundo corte, a relação $\mathrm{N}: \mathrm{S}$ nas lâminas de folhas maduras apresentou os resultados ajustando-se a modelo polinomial de regressão a ocorrência de um ponto de sela. A relação N:S nestas lâminas variou de 2,6:1 a 23,4:1 (Figura 39).

As maiores relações $\mathrm{N}: \mathrm{S}$ foram observadas em condições de altas doses de nitrogênio (406 a $462 \mathrm{mg} \mathrm{L}^{-1}$ ) associadas a baixa dose de enxofre $\left(3,2 \mathrm{mg} \mathrm{L}^{-1}\right.$ ), e as menores relações $\mathrm{N}: \mathrm{S}$ na mais baixa dose de nitrogênio $\left(14 \mathrm{mg} \mathrm{L}^{-1}\right)$ associada à altas doses de enxofre (60,8 a $\left.80 \mathrm{mg} \mathrm{L}^{-1}\right)$, na solução nutritiva.

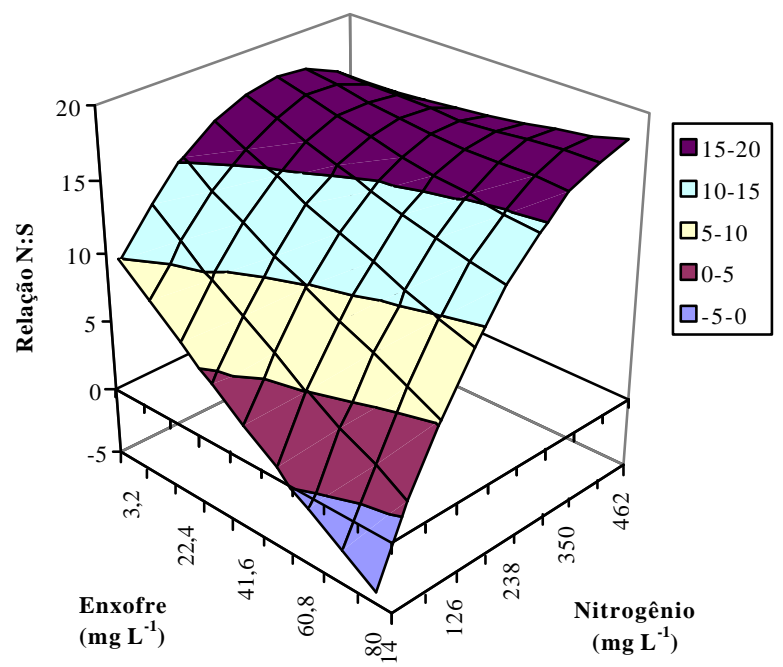

$Y=9,7538+0,0608 N-0,0005 N^{2}+-0,2121 S+0,00026 S^{2}+0,0004 N S\left(R^{2}=0,60\right)$

Figura 38 - Relação N:S nas lâminas de folhas maduras do capim-Marandu, na ocasião do primeiro corte, em função das combinações de doses de nitrogênio e de enxofre na solução nutritiva. 
As lâminas de folhas maduras mostraram a menor variação (1,8 vezes) na relação $\mathrm{N}: \mathrm{S}$, quando Santos (1997) aplicou doses de enxofre entre 0 e $80 \mathrm{mg} \mathrm{L}^{-1}$, no segundo corte do capim-Braquiária.

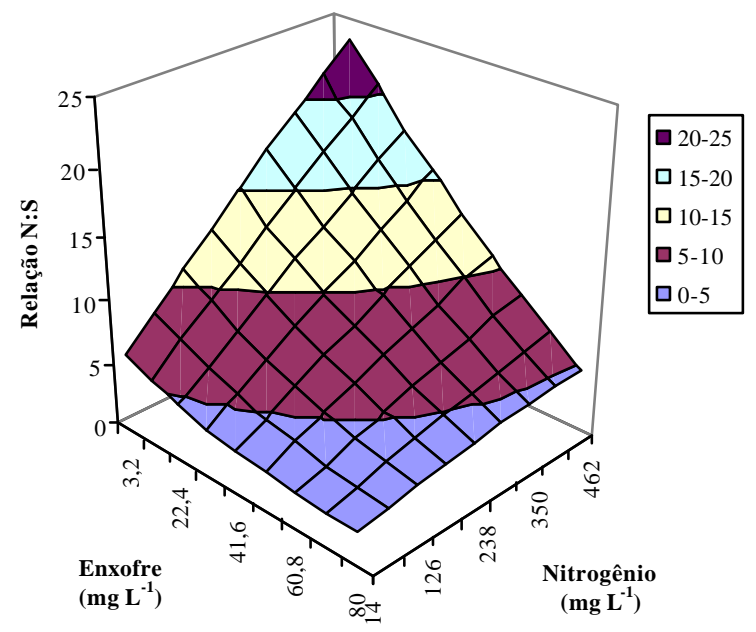

$Y=6,1369+0,0413 N-0,000004 N^{2}-0,1009 S-0,0007 S^{2}-0,0004 N S\left(R^{2}=0,82\right)$

Figura 39- Relação N:S nas lâminas de folhas maduras do capim-Marandu, na ocasião do segundo corte, em função das combinações de doses de nitrogênio e de enxofre na solução nutritiva.

\subsubsection{Relação N:S nos colmos mais bainhas e nas raízes}

A interação entre as doses de nitrogênio e de enxofre na solução nutritiva não foi significativa $(\mathrm{P}<0,05)$ para a relação $\mathrm{N}: \mathrm{S}$ nos colmos+bainhas, na ocasião do primeiro e segundo cortes do capim, bem como para essa relação nas raízes. Respostas significativas $(\mathrm{P}>0,05)$ também não foram observadas para as doses individuais de nitrogênio e de enxofre, na relação N:S nessas partes da plantas. 
Monteiro (1986) estudando os efeitos da aplicação de enxofre em Paspalum notatum observou que a relação $\mathrm{N}: \mathrm{S}$ nas raízes e estolões deste capim foi de 4,1:1 tanto na parcela que recebeu como naquela que não recebeu enxofre.

\subsection{Sintomatologia de carência de nitrogênio e enxofre}

Durante o período experimental alguns vasos apresentaram visualmente sintomas de deficiência de nitrogênio e enxofre. Em condições de altas doses de nitrogênio e baixas doses de enxofre observou-se visualmente os sintomas de deficiência de enxofre nas plantas e o contrário também era verdadeiro, essas deficiências também puderam ser comprovadas com os resultados apresentados, ressaltando portanto a necessidade e importância do equilíbrio na relação N/S para o desenvolvimento adequado da planta (Figuras 40 e 41).

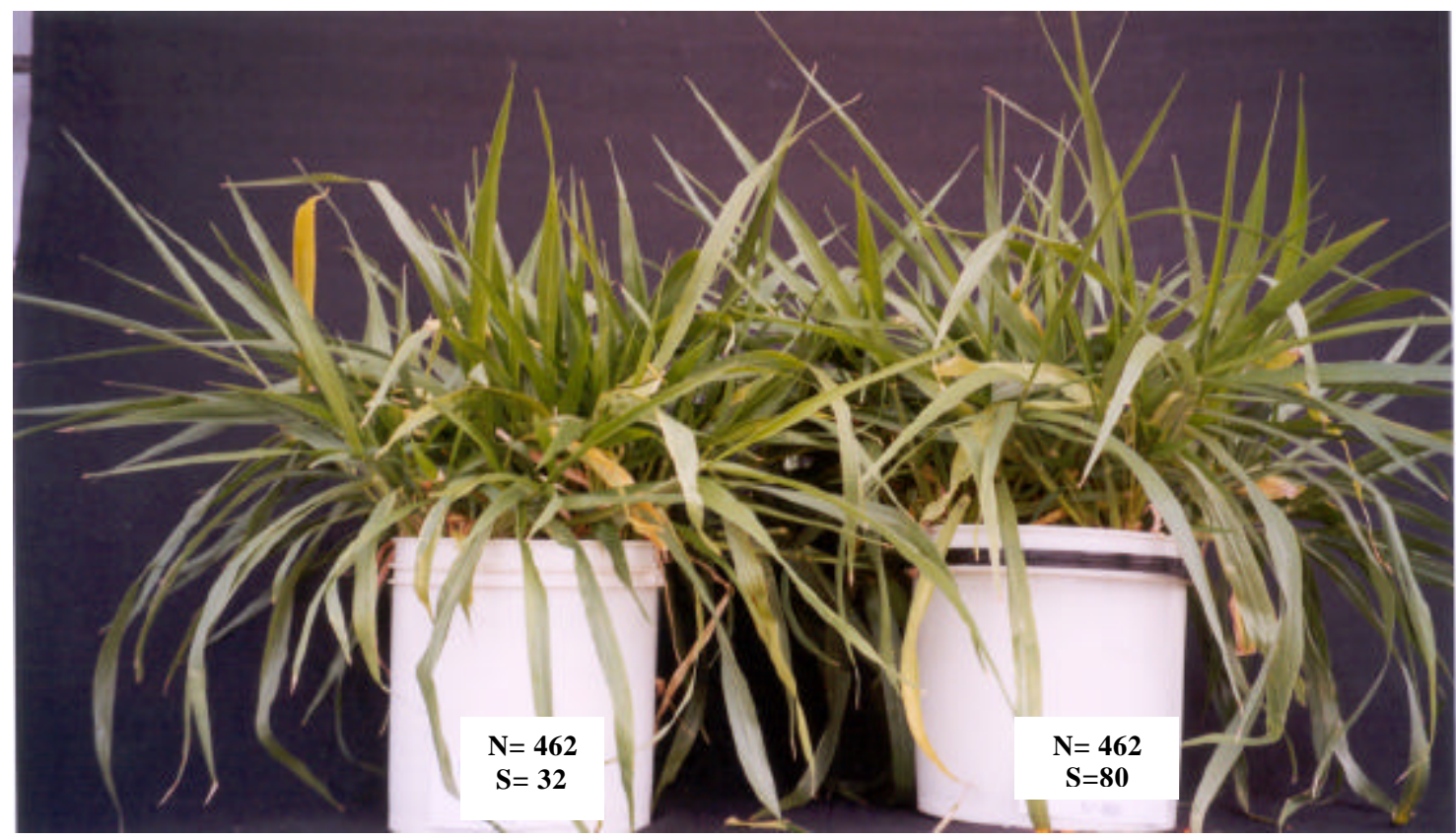

Figura 40 - Plantas submetidas a combinações de doses de nitrogênio (462 mg L $\left.{ }^{-1}\right)$ e de enxofre (32 e $80 \mathrm{mg} \mathrm{L}^{-1}$ ) na solução nutritiva. 


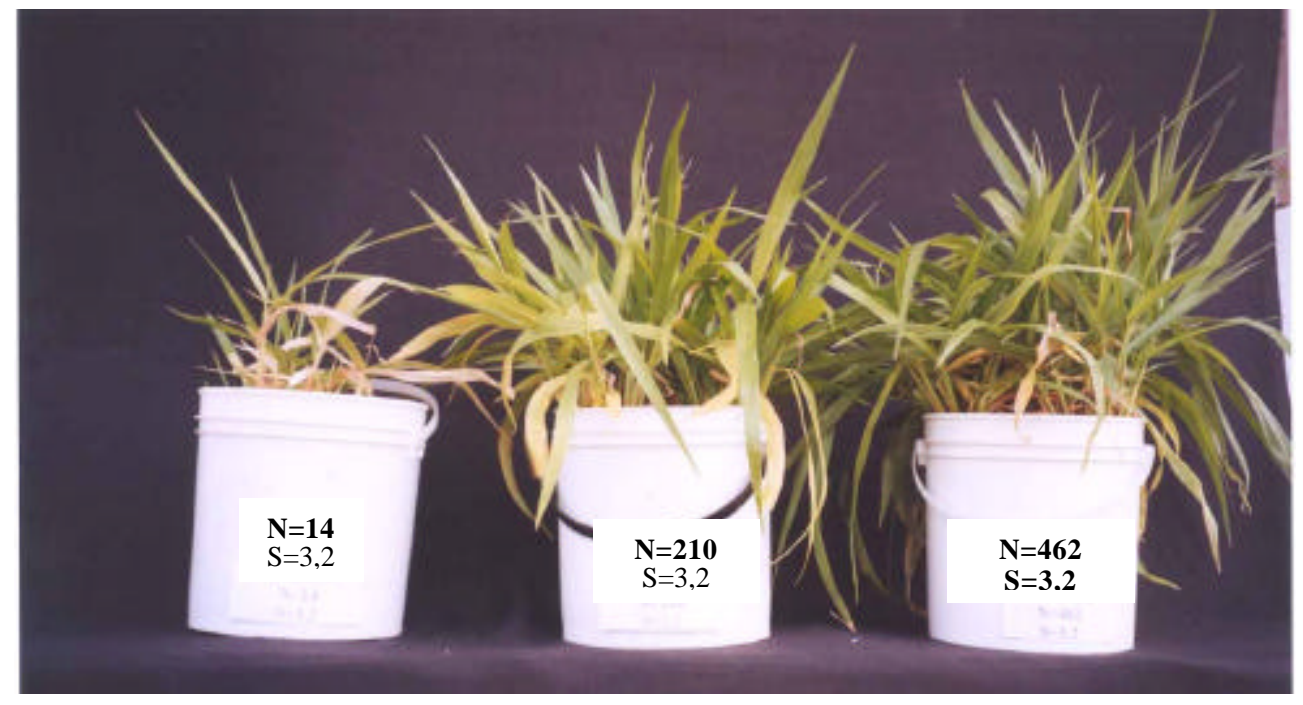

Figura 41 - Plantas submetidas a combinações de doses de nitrogênio ( 14, 210 e $\left.462 \mathrm{mg} \mathrm{L}^{-1}\right)$ e de enxofre de $\left(3,2 \mathrm{mg} \mathrm{L}^{-1}\right)$ na solução nutritiva. 


\section{CONCLUSÕES}

* A interação entre doses de nitrogênio e de enxofre é determinante para número de perfilhos; número de folhas; estimativa do teor de clorofila, (SPAD); área foliar; produção de massa seca da parte aérea; concentração de nitrogênio em folhas emergentes e nas raízes; concentração de enxofre e relação N:S em folhas emergentes, lâminas de folhas recém-expandidas e lâminas de folhas maduras do capim-Marandu.

* Doses de nitrogênio de no mínimo $400 \mathrm{mg} \mathrm{L}^{-1}$ são necessárias para maximizar a concentração de nitrogênio em folhas emergentes, lâminas de folhas recémexpandidas, lâminas de folhas maduras e colmos+bainhas, e o comprimento e a superfície total do sistema radicular do capim-Marandu.

* A máxima concentração de nitrogênio no tecido do capim-Marandu ocorre nas folhas emergentes (31,6 $\left.\mathrm{g} \mathrm{kg}^{-1}\right)$ enquanto a de enxofre é verificada nos colmos+bainhas $\left(2,8 \mathrm{~g} \mathrm{~kg}^{-1}\right)$.

* A aplicação de baixa dose de nitrogênio resulta em crescimento reduzido e em estreita relação $\mathrm{N}: \mathrm{S}(2,8: 1)$ nas lâminas de folhas recém-expandidas da forrageira, enquanto alta dose de nitrogênio em presença de baixa dose de enxofre proporciona deficiência de enxofre concomitantemente á larga relação N:S (37,2:1) naquelas lâminas foliares do capim-Marandu.

- Há necessidade de cuidar do fornecimento de enxofre, quando o nitrogênio é suprido em quantidade apreciável para o capim-Marandu 


\section{REFERÊNCIAS BIBLIOGRÁFICAS}

ABREU, J.B.R. Produção e nutrição dos capins Tanzânia-1 e Marandu em função de estádios de crescimentos e adubação nitrogenada. Piracicaba, 1999. 99p. Tese (Doutorado) - Escola Superior de Agricultura "Luiz de Queiroz", Universidade de São Paulo.

ABREU, J.B.R.; MONTEIRO, F.A. Produção e nutrição do capim-Marandu em função de adubação nitrogenada e estádios de crescimento. Boletim de Indústria Animal, v.56, p.137-146, 1999.

AGUIAR, A.P.A. Manejo da fertilidade do solo sob pastagem: o uso do nitrogênio. Guaíba: Agropecuária, 1998. 120p.

ALCÂNTARA, P.B.; BUFARAH, G. Plantas forrageiras gramíneas e leguminosas. São Paulo: Nobel, 1992. 150p.

ALEXANDRINO, E.; NASCIMENTO JÚNIOR, D.; MOSQUIM, P.R.; REGAZZI, A.J.; FONSECA, D.M; SOUZA, P,S. Efeito da adubação nitrogenada e da freqüencia de corte na rebrotação da Brachiaria brizantha cv. Marandu IICaracterísticas morfogênicas e estruturais. In: SIMPÓSIO INTERNACIONAL GRASSLAND ECOPHYSIOLOGY AND GRAZING ECOLOGY, Curitiba, 1998. Anais, Curitiba: IAPAR, 1999. p. 287-290.

ALVIM, M.J.; MOOJEN, E.L. Efeitos de fontes e níveis de nitrogênio e práticas de manejo sobre a produção e qualidade da forragem azevém anual. Revista da Sociedade Brasileira de Zootecnia, v.13, p.243-253, 1995. 
ANDRADE, J.B.; BENINTENDE, R.P.; FERRARI JÚNIOR, E.; PAULINO, V.T.; HENRIQUE, W. Efeitos das adubações nitrogenada e potássica na produção e composição da forragem da Brachiaria ruziziensis. Pesquisa Agropecuária Brasileira, v.31, p.617-620, 1996.

BARROS, C.O. Produção e qualidade da forragem do capim-Tanzania estabelecido com milheto, sob três doses de nitrogênio. Lavras, 2000. 72p. Dissertação (Mestrado) - Universidade Federal de Lavras.

BEEVERS, L.; SHRADER, L.E.; FLISCHER, D.; HAGEMAN, R,H. The role of light and nitrate in the induction of nitrate redutase in radish cotyledons and maize seedings. Plant Physiology, v.40, p.691-698. 1969.

BOIN, C. Produção animal em pastos adubados. In: SIMPÓSIO SOBRE CALAGEM E ADUBAÇÃO DE PASTAGENS, 1., Nova Odessa, 1985. Anais. Nova Odessa: Potafós, 1986. p.383-419.

BRAGA, G.J. Resposta do capim-mombaça (Panicum maximum Jacq.) a doses de nitrogênio e intervalos de corte. Pirassununga, 2001. 121p. Dissertação (Mestrado)Faculdade de Zootecnia e Engenharia de Alimentos, Universidade de São Paulo.

BROUWER, R. Nutritive influences on the distribution of dry matter in the plant. Netherlands Journal of Agricultural Sciences, v.10, p.399-342, 1962.

CEDEÑO, J.A.G. Estudo de gramíneas forrageiras tropicais em diferentes idades. Lavras, 2001. 66p. Dissertação (Mestrado) - Universidade Federal de Lavras.

CHAPMAN, D.F.; LAMAIRE, G. Morphogenetic and structural determinants of plant regrowth after defoliation. In: INTERNATIONAL GRASSLAND CONGRESS, 17., Palmerston North, 1993. Proceedings. Palmerston North: New Zealand Grassland Association, 1993. p. 95-104.

COLOZZA, M.T. Rendimento e diagnose foliar dos capins Aruana e Mombaça cultivados em Latossolo Vermelho - Amarelo adubado com doses de nitrogênio. Piracicaba, 1998. 127p. Tese (Doutorado) - Escola Superior de Agricultura "Luiz de Queiroz", Universidade de São Paulo. 
COLOZZA, M.T.; KIEHL, J.C.; WERNER, J.A.; SCHAMMASS, E. A. Respostas de Panicum maximum cultivar Aruana a doses de nitrogênio. Boletim de Indústria Animal, v.57, p.21-32, 2000.

CORRÊA, B.D.Doses de nitrogênio e de magnésio afetando aspectos produtivos e bioquímicos dos capins Colonião, Tanzânia 1 e Vencedor. Piracicaba: 1996. 76p. Dissertação (Mestrado) - Escola Superior de Agricultura "Luiz de Queiroz", Universidade de São Paulo.

CORSI, M.; NÚSSIO, L.G. Manejo do capim - Elefante: correção e adubação do solo. In: SIMPÓSIO SOBRE MANEJO DA PASTAGEM, 10., Piracicaba, 1992. Anais. Piracicaba: FEALQ, 1992. p.87-116.

COSTA, M.N.X. Influência de épocas e doses de adubação nitrogenada na produção estacional de dois capins. Piracicaba, 1999. 63p. Dissertação (Mestrado) - Escola Superior de Agricultura “Luiz de Queiroz”, Universidade de São Paulo.

CUNHA, M.A.D.; LEITE, G.G.; DIOGO, J.M.S.; VIVALDI, L.J. Características morfológicas do Paspalum citratum cv. Pojuca submetido ao pastejo rotacionado. Dinâmica de perfilhamento e elongação de folhas. Revista da Sociedade Brasileira de Zootecnia, v.30, p.935-940, 2001.

CRESTANA, S; GUIMARÃES, M.F.; JORGE, L.A.C.; RALISCH, R.; TOZZI, C.L.; TORRE, A.; VAZ, C.M.P. Avaliação da distribuição de raízes no solo auxiliada por processamento de imagens digitais. Revista Brasileira de Ciência do Solo, v.18, p.365-371, 1994.

CRUZ, P.; BOVAL, M. Effect of nitrogen on some morphogenetical traits of temperate and tropical perennial forage grasses. In: SIMPÓSIO INTERNACIONAL GRASSLAND ECOPHYSIOLOGY AND GRAZING ECOLOGY, Curitiba, 1998. Anais, Curitiba: IAPAR, 1999.p. 134-150.

DIJKSHOORN W.; LAMPE J.E.M. A method of diagnosing the sulphur nutrition status of herbage. Plant and Soil, v.13, p. 227-241, 1960.

DIJKSHOORN W.; VAN WIJK, A.L. The sulphur requirements of plants as evidence by the sulphur-nitrogen ratio in the organic matter. Plant and Soil, v.26, p. 129-157, 1967. 
FAQUIN, V.; CURI, N.; MARQUES, J.J.G.S. M.; TEIXEIRA, W.G.; EVANGELISTA, A.R.; SANTOS,D.; CARVALHO, M.M. Limitações nutricionais para gramíneas forrageiras em Cambissolo álico da microregião Campos da Mantiqueira-MG, Brasil. 2. Nutrição em macro e micronutrientes. Pasturas Tropicales, v.17, p.17-22, 1995.

FERRARI JÚNIOR, E.; ANDRADE, J.B. DE; PEDREIRA, J.V.S.; COSENTINO, J.R.; SCHAMMASS, E.A. Produção de feno de Brachiaria decumbens e Brachiaria brizantha cultivar Marandu sob três frequiências de corte. Boletim de Indústria Animal, v. 51, p.49-51, 1994.

FERRARI NETO, J. Limitações nutricionais para o Colonião (Panicum maximum Jacq.) e ( Brachiaria decumbens Stapf.) em Latossolo da região noroeste do Estado de Paraná. Lavras, 1991. 126p. Dissertação (Mestrado) - Escola Superior de Agricultura de Lavras.

GUEDES, L.M.; GRAÇA, D.S.; MORAIS, M.G.; ANTUNES, R. C.; GONÇALVES, L. C. Influência da aplicação de gesso na produção de matéria seca, na relação nitrogênio: enxofre e concentrações de enxofre, cobre, nitrogênio e nitrato em pastagens de Brachiaria decumbens Stapf. Arquivo Brasileiro de Medicina Veterinária e Zootecnia, v.52, 2000. http://www.scielo.br (10/abr./2001).

HAAG, H.P. Nutrição mineral de forrageiras no Brasil. Campinas: Fundação Cargill, 1984. $152 \mathrm{p}$.

HOFFMANN, C.R. Nutrição mineral e crescimento da braquiária e do colonião, sob influência das aplicações de nitrogênio, fósforo, potássio e enxofre em Latossolo da região noroeste do Paraná. Lavras, 1992. 204p. Dissertação (Mestrado) - Escola Superior de Agricultura de Lavras.

LANGER, R.H.M. Tillerging in herbage grasses. Herbage Abstracts, v.33, p.141-148, 1963.

LAVRES JÚNIOR, J. Combinações de doses de nitrogênio e potássio para o capimMombaça. Piracicaba, 2001. 103p. Dissertação (Mestrado) - Escola Superior de Agricultura "Luiz de Queiroz”, Universidade de São Paulo. 
LEMAIRE, G.; AGNUSDEI, M. Leaf tissue turn-over and efficiency of herbage utilisation. In: SIMPÓSIO INTERNACIONAL GRASSLAND ECOPHYSIOLOGY AND GRAZING ECOLOGY, Curitiba, 1998. Anais, Curitiba: IAPAR, 1999. p. $165-184$.

LITTEL,R.C.; MOTT G.O. Computer assisted design and analysis of response surface experiments in agronomy. Soil and Crop Society of Florida Proceedings. v.34, p.94-97, 1975.

LOPES, A.S. Manual internacional de fertilidade do solo. Piracicaba: Potafos, 1998. $177 \mathrm{p}$.

MACHADO, L.C.P. Produtividade do pasto. São Paulo: Mestre Jou, 1974. p.53-54.

MALAVOLTA, E. Elementos de nutrição mineral de plantas. São Paulo: Ceres,1980. $251 \mathrm{p}$.

MALAVOLTA, E. O enxofre na agricultura, situação atual, perspectivas e sugestões. In: SIMPÓSIO: P, Ca, Mg, S, MICRONUTRIENTES: SITUAÇÃO ATUAL E PERSPECTIVAS NA AGRICULTURA, São Paulo, 1984. Anais. São Paulo: Manah, 1986. p.101-108.

MANARIN, C.A. Respostas fisiológicas, bioquímicas e produtivas do capim - Mombaça a doses de nitrogênio. Piracicaba: 2000. 58p. Dissertação (Mestrado) - Escola Superior de Agricultura "Luiz de Queiroz", Universidade de São Paulo.

MARSCHNER, H. Mineral nutrition of higher plants. London: Academic Press, 1997. 889p.

MARQUES, J.J.G.S.M.; CURI, N.; FAQUIN, V.; TEIXEIRA, W.G.; EVANGELISTA, A.R.; SANTOS, D.; CARVALHO, M.M. Limitações nutricionais para gramíneas forrageiras em Cambissolo álico da Microregião Campos da Mantiqueira-MG, Brasil. Produção de matéria seca e perfilhamento. Pasturas Tropicales, v.17, p.12$16,1995$.

MATTOS, W.T. Avaliação de pastagem de capim-braquiária em degradação e sua recuperação com suprimento de nitrogênio e enxofre. Piracicaba, 2001. 97p. Tese (Doutorado) - Escola Superior de Agricultura "Luiz de Queiroz”, Universidade de São Paulo. 
MENDES, L.A. Efeitos de doses de nitrogênio em gramíneas do gênero Cynodon. Lavras, 2000. 56p. Dissertação (Mestrado)- Escola Superior de Agricultura de Lavras, Universidade Federal de Lavras.

MINOLTA CAMERA CO. Manual for Chlorophyllmeter SPAD-502. Osaka, 1989. $22 \mathrm{p}$.

MONTEIRO, F.A. Sulphur fertilization and nutrient distribution in a Florida Spodosol profile under white clover - Pensacola bahiagrass. Gainesville, 1986. 182p. Thesis (Doctor) - University of Florida.

MONTEIRO, F.A.; CARRIEL, J.M. Aplicação de níveis de enxofre na forma de gesso para o cultivo do capim-Colonião em dois solos arenosos do Estado de São Paulo. Boletim de Indústria Animal, v.44, p. 335-347, 1987.

MONTEIRO, F.A.; WERNER, J.C. Efeitos das adubações nitrogenadas e fosfatada em capim-Colonião, na formação e em pasto estabelecido. Boletim de Indústria Animal, v. 34, p.91-101,1977.

MONTEIRO, F.A.; CARRIEL, J.M., MARTINS, L.; CASTRO, J.V. LIEM, T.H. Aplicação de níveis de enxofre na forma de gesso, para cultivo de leguminosas forrageiras. Boletim de Indústria Animal, v.40, p. 229-240, 1983.

MONTEIRO, F.A.; RAMOS, A.K.B.; CARVALHO, D.D.; ABREU, J.B.R.; DAWB, J. A.S.; SILVA, J.E.P; NATALE, W. Cultivo de Brachiaria brizantha Stapf. cultivar Marandu em solução nutritiva com omissão de macronutrientes. Scientia Agricola, v.52, p.135-141,1995.

MULDER, E.G.; BOXMA, R.; VAN VEEN, W.L. The effect of molybdenum and nitrogen deficiencies on nitrato reduction in plant tissue. Plant and Soil, v.10, p.335-355, 1959.

NABINGER, C.; MEDEIROS, R.B. Produção de sementes de Panicum maximum Jcaq.. In: SIMPÓSIO SOBRE MANEJO DA PASTAGEM, 14., Piracicaba, 1992. Anais. Piracicaba: FEALQ, 1995. p.59-128.

NUNES, S.G.; BOOK, A. PENTEADO, M.I.O; GOMES, D.T. Brachiaria brizantha cv. Marandu. Campo Grande: EMPRABA, CNPGC, 1985. 31p. (EMBRAPA, CNPGC. Documento 21) 
PACIULLI, A. S. Efeito de diferentes épocas de corte e doses de nitrogênio sobre a produção, composição química e digestibilidade "in vitro" de três gramíneas tropicais do gênero Cynodon. Lavras, 1997. 92p. Dissertação (Mestrado) Universidade Federal de Lavras.

RAIJ, B.van. Fertilidade do solo e adubação. Piracicaba: Ceres, 1991. 343p.

RIBEIRO, K.G. Rendimento forrageiro e valor nutritivo do capim-Elefante "Anão", sob cinco doses de nitrogênio, ao atingir 80 e $120 \mathrm{~cm}$ de altura. Viçosa, 1995. 60p. Dissertação (Mestrado) - Universidade Federal de Viçosa.

RIBEIRO, K.G. Rendimento forrageiro e valor nutritivo do Capim-Tifton 85, sob diferentes doses de nitrogênio e idades de rebrota, e na forma de feno, com bovinos. Viçosa, 2000. 107p. Tese (Doutorado) - Universidade Federal de Viçosa.

RODRIGUES, R.C. Cálcario, nitrogênio e enxofre para a recuperação do capimBraquiária cultivado em solo proveniente de uma pastagem degradada. Piracicaba, 2002. 141p. Dissertação (Mestrado) - Escola Superior de Agricultura "Luiz de Queiroz", Universidade de São Paulo.

RUGGIERI, A.C.; FAVORETTO, V.; MALHEIROS, E.B. Características de crescimento e produção de matéria seca da Brachiaria brizantha (Hochst) Stapf. cv. Marandu em função de níveis de nitrogênio e regimes de corte. Boletim de Indústria Animal, v.51, p.149-155,1994.

SANTOS, A.R. Diagnose nutricional e respostas do capim-Braquiária submetido a doses de nitrogênio e enxofre. Piracicaba, 1997. 115p. Tese (Doutorado) - Escola Superior de Agricultura "Luiz de Queiroz", Universidade de São Paulo.

SANTOS, A.R.; MONTEIRO, F. A. Produção e perfilhmento de Brachiaria decumbens Stapf. em função de doses de enxofre. Scientia Agricola, v.56, p.689-692, 1999.

SANTOS JÚNIOR, J.D.G. Dinâmica de crescimento e nutrição do capim - Marandu submetido a doses de nitrogênio. Piracicaba, 2001. 79p. Dissertação (Mestrado) Escola Superior de Agricultura “Luiz de Queiroz”, Universidade de São Paulo.

SARRUGE, J.R. Soluções nutritivas. Summa Phytopathologica, v.1, p.231-233, 1975.

SARRUGE, J.R.; HAAG, H.P. Análises químicas em plantas. Piracicaba: ESALQ, 1974. 54p. 
SAS INSTITUTE. The SAS-system for windows: release 6.08 (software). Cary, 1996.

TERUEL, D.A.; DOURADO NETO, D.; HOPMANS, J.W.; REICHARDT, K. Modelagem matemática como metodologia de análise do crescimento e arquitetura de sistemas radiculares. Scientia Agricola, v.57, p.683-691, 2000.

VITTI, G.C. O enxofre na agricultura, situação atual, perspectivas e sugestões. In: SIMPÓSIO: $\mathrm{P}, \mathrm{Ca}, \mathrm{Mg}, \mathrm{S}$, MICRONUTRIENTES SITUAÇÃO ATUAL E PERSPECTIVAS NA AGRICULTURA, São Paulo, 1984. Anais. São Paulo: Manah, 1986. p.101-108.

WERNER, J.C. Adubação de pastagens. Nova Odessa: Instituto de Zootecnia, 1984. 49p. (Relatório Técnico,18)

WERNER, J.C.; MONTEIRO, F. A. Respostas das pastagens a aplicação de enxofre. In: Simpósio: ENXOFRE E MICRONUTRIENTES NA AGRICULTURA BRASILEIRA, Londrina, 1988. Anais. Londrina: Embrapa, CNPS; IAPAR, 1988. p.87-102.

WERNER, J.C.; QUAGLIATO, J.L.; MARTINELLI, D. Ensaio de fertilização do colonião com solo da "Noroeste". Boletim de Indústria Animal, v. 24, p.19-167, 1967.

WHITEHEAD, D.C. Grassland nitrogen. Wallingford: CAB International, 1995. 397p.

WOODHOUSE JUNIOR, W.W. Long-term fertility requirements of coastal bermudagrass. Agricultural Journal, v.61, p.705-708, 1969. 